\author{
UNIVERSIDADE DE SÃO PAULO \\ FACULDADE DE FILOSOFIA, LETRAS E CIÊNCIAS HUMANAS \\ DEPARTAMENTO DE LINGÜÍSTICA \\ PROGRAMA DE ESTUDOS LINGÜÍSTICOS E LITERÁRIOS EM INGLÊS
}

GABRIELA CORBISIER TESSITORE

A força do estético: reflexões sobre a refuncionalização da arte em "Pós-modernismo ou a lógica cultural do capitalismo tardio", de Fredric Jameson.

(Versão corrigida)

v. 1

São Paulo

2013 


\author{
UNIVERSIDADE DE SÃO PAULO \\ FACULDADE DE FILOSOFIA, LETRAS E CIÊNCIAS HUMANAS \\ DEPARTAMENTO DE LINGÜÍSTICA \\ PROGRAMA DE ESTUDOS LINGÜÍSTICOS E LITERÁRIOS EM INGLÊS
}

\title{
A força do estético: reflexões sobre a refuncionalização da arte em "Pós-modernismo ou a lógica cultural do capitalismo tardio", de Fredric Jameson.
}

(Versão corrigida)

\author{
Gabriela Corbisier Tessitore
}

Dissertação apresentada à Banca Examinadora da Universidade de São Paulo, Programa de Pós-Graduação em Estudos Linguísticos e Literários em Inglês, como requisito para a obtenção do titulo de mestre em Letras.

Orientador: Prof. Dr. Daniel Puglia.

v.1

São Paulo

2013 


\section{GABRIELA CORBISIER TESSITORE}

Dissertação apresentada à Banca Examinadora da Universidade de São Paulo, Programa de Pós-Graduação em Estudos Linguísticos e Literários em Inglês, como requisito para a obtençãodo titulo de mestre em Letras.

Data de aprovação:

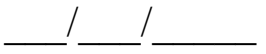

Banca Excaminadora:

Prof(a). Dr.(a) Maria Elisa Cevasco

(USP)

Prof. Dr. José Corrêa Leite

(PUC)

Prof. Dr. Daniel Puglia

(USP)

São Paulo

2013 
À minha família e aos meus amigos. 


\section{AGRADECIMENTOS}

É com imensa satisfação que agradeço a todos aqueles que, de alguma forma, contribuíram para a realização deste trabalho.

Primeiramente, agradeço aos meus pais, que sempre me apoiaram em minhas decisões, com todo amor, e por me darem forças para prosseguir. Agradeço, ainda, à minha amada e onipresente avó, à minha tia e madrinha mais que especial e ao meu querido padrinho.

Ao Prof. Dr. Daniel Puglia, meu orientador, que acreditou no meu trabalho e que, com dedicação e paciência, esteve presente em todas as etapas desta jornada. Agradeço, sobretudo, para além da orientação, pela sincera amizade e cuidado.

Ao Prof. Dr. José Corrêa, por sua colaboração essencial no meu processo de formação desde os seus primórdios, pelo carinho a mim dedicado, bem como pelos seus ensinamentos, substanciais para a concretização desta dissertação.

À Profa. Dra. Maria Elisa Cevasco, por sua leitura atenciosa e sugestões, que contribuíram enormemente para o desenvolvimento desta pesquisa.

Ao Professor João Carlos Guedes, pelo seu papel de mestre em sentido estrito: a priori, despertando em mim o prazer pelo conhecimento; depois, por me guiar, certeiramente, ao lugar onde hoje estou (pois, seguramente, não saberia em qual outro estar).

Ao Professor Luiz Felipe Pondé, pelas agradáveis conversas filosóficas, em que a pauta, pode-se dizer, sempre girava em torno do tema "materialismo histórico versus natureza humana"; pauta essa, que, creio eu, nunca será superada (no sentido hegeliano).

Ao querido Professor Rubens Fernandes Junior, por ter me dado a oportunidade de ser professora, e porporcionar a todos nós um ambiente de trabalho que agrega vivências tão significativas.

Aos meus amigos do trabalho, por me aguentarem. 
Com a devida vênia a Hegel, pareceria agora que o real é irracional, e o racional irreal.

(Terry Eagleton, As Ilusões do Pós-modernismo)

A substituição mentirosa do individual pelo esteriotipado há de se tornar insuportável aos homens.

(Theodor Adorno, Dialética do Esclarecimento)

Uma nova forma de miséria surgiu com esse monstruoso desenvolvimento da técnica, sobrepondo-se ao homem. (...) Aqui se revela, com toda clareza, que nossa pobreza de experiências é apenas uma parte da grande pobreza que recebeu novamente um rosto, nítido e preciso como o do mendigo medieval. Pois qual o valor de todo o nosso patrimônio cultural, se a experiência não mais o vincula a nós? (...) Sim, é preferível confessar que essa pobreza de experiência não é mais privada, mas de toda a humanidade. Surge assim uma nova barbárie. (Walter Benjamin, Experiência e Pobreza) 


\section{RESUMO}

Este estudo pretende investigar, a partir do confronto da tese elaborada por Fredric Jamseon em "Pós-modernismo ou a lógica cultural do capitalismo tardio" com uma análise voltada para a materialidade histórica, o alcance da fusão da base e da superestrutura no capitalismo tardio. Nesse sentido, busca esclarecer em que medida o ensaio de Jameson ajuda a compreender a dominância do pós-modernismo, e o quanto é insuficiente, por outro lado, para explicar a situação da produção material nas regiões em que o neoliberalismo e a globalização não estão desenvolvidos, e que, portanto, não respondem integralmente à lógica cultural que anima o capitalismo financeiro. Noutras palavras, reinvindica-se o "teste da realidade" da ideologia do pós-modernismo para além das fronteiras do mundo anglo-saxão. Sendo assim, é debatida a possibilidade da tese de Jameson sobre a fusão da base e da superestrutura no estágio do capitalismo tardio estar circunscrita aos países onde ambos, a acumulação flexível e a globalização financeira, de fato, vingaram. Sem prejuízo do conteúdo da crítica, esta pesquisa visa igualmente traçar considerações acerca da prosa jamesoniana, a fim de apontar para alguns de seus efeitos e sua relação com o caráter de denúncia apresentado no ensaio e estabelecer suas correspondências com o método da Escola de Frankfurt, mais especificamente, o de Theodor Adorno. 


\begin{abstract}
This study intends to investigate, from the confrontation of the thesis prepared by Fredric Jameson in "Postmodernism or the Cultural Logic of Late Capitalism", with an analysis on the historical materiality, the extent of the fusion of the base and superestructure in late capitalism. In this sense, it seeks to clarify where Jameson's essay helps to understand the dominance of postmodernism and how it is unsufficient to explain the situation of material production in areas where neoliberalism and globalization are not developed and, therefore, do not respond fully to the cultural logic that animates financial capitalism. In other words, it is necessary a "reality test" of the ideology of postmodernism beyond the borders of the Anglo-Saxon world. Thus, it is discussed the possibility of Jameson's thesis of base and superestructure stage of late capitalism be restricted to countries where both flexible accumulation and financial globalization indeed ocurred. This research also aims to make considerations about Jamson's prose in order to point some of its effects and its relations with the denouncing contents of this essay and estabilish their correspondences with the method of the Frankfurt School, more specifically, the one of Theodor Adorno.
\end{abstract}




\section{SUMÁRIO}

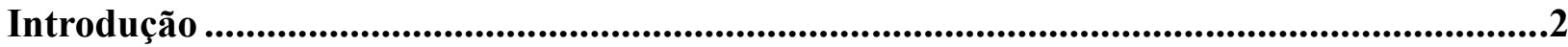

1. Iniciação ao debate: reflexões sobre o modernismo, o pós-modernismo e a pósmodernidade.

2. Breve histórico de uma fase capitalista: do Fordismo à Acumulação Flexível ..................44

2.1 Projeto Moderno, Modernismo e Pós-Modernismo .............................................................44

2.2 A Transição ...........................................................................................................................48

2.3 O Fordismo, o Keynesianismo, a Intervenção Estatal........................................................50

2.4 A Acumulação Flexível...............................................................................................................55

3. O Capitalismo Tardio e a lógica cultural de Jameson ..........................................................61

3.1 O Neoliberalismo em foco: reflexões sobre sua abrangência ............................................61

3.1.1 O debate acadêmico e seus primeiros efeitos ..........................................................63

3.2 O particular elevado ao universal: a crise fiscal de Nova York e o governo de Reagan ..............................................................................................................................65

3.2.1 O caso da Grã-Bretanha e Margaret Thatcher .....................................................69

3.3 O desenvolvimento desigual do neoliberalismo ao redor do globo ..................................71

3.4 Quaisquer contradições do Estado Neoliberal ...................................................................73

3.5 A fusão da base com a superestrutura e o pós-modernismo como dominante cultural............................................................................................................................................77

Considerações finais........................................................................................................................91

Bibliografia ........................................................................................................................99 


\section{Introdução}

A pós-modernidade remonta, em suas origens, segundo periodização de Fredric Jameson, ao fim dos anos 50 ou começo dos anos 60. ${ }^{1}$ Desse modo, o clássico ensaio de Adorno e Horkheimer - "A indústria cultural: o esclarecimento como mistificação das massas" -, concebido em 1947, teorizou, pode-se dizer, os primeiros impasses enfrentados pela cultura, sob a égide do imperativo da racionalidade dos fins, frente às novas técnicas de produção e circulação.

A mudança do paradigma funcional da arte adveio ainda com a reprodutibilidade de seu novo modo de acesso, no que tange ao público consumidor. O salto quantitativo da exponibilidade da obra, em um modo qualitativamente novo, alterou a relação das massas com a arte. Orientar a realidade em função das massas, e as massas em função da realidade foi um processo que determinou novas condições para o pensamento e para a intuição. ${ }^{2}$

Se o número substancialmente maior de participantes produziu um novo modo de participação, uma nova atitude em relação à arte, esse modo não foi, de fato, canalizado para a adequação das estruturas sensíveis, segundo as exigências impostas ao aparelho perceptivo do homem moderno, conforme as esperanças benjaminianas. Adorno e Horkheimer, assim como Benjamin, entenderam a estrutura da indústria cultural como prolongamento da estrutura do processo de trabalho; entretanto, quando falam em "habituar os sentidos ao novo ritmo", segundo a "lei da sua própria forma" 3 , imperam a negatividade e a descrença com relação a qualquer possibilidade emancipadora do meio, dado a predominância do efeito, e "o peso específico do aparelho (...) como partes do mecanismo econômico de seleção". ${ }^{4}$

A indústria cultural foi analisada pelos frankfurtianos não como um avanço da técnica pura e simplesmente, mas sim a partir de sua função na economia, segundo a razão planejadora típica da sociedade administrada ${ }^{5}$ :

\footnotetext{
1 Fredric Jameson. Pós-modernismo ou a lógica cultural do capitalismo tardio. São Paulo: Ática, 2007 , p. 30.

Idem, ibidem, p.177.

3 Adorno e Horkheimer, "A indústria cultural: o esclarecimento como mistificação das massas". In: Dialética do Esclarecimento. Rio de Janeiro: Zahar, 1985, p. 130.

${ }^{4}$ Idem, ibidem, p. 115.

${ }^{5}$ Sobre a condição dos indivíduos, na sociedade administrada, dizem os autores: "rebaixados ao nível de simples objetos do sistema administrativo, que preforma todos os setores da vida moderna, inclusive a linguagem e a
} 
O novo não é o caráter mercantil da obra de arte, mas o fato de que, hoje, ele se declara deliberadamente como tal, e é o fato de que a arte renega sua própria autonomia, incluindo-se orgulhosamente entre os bens de consumo, que lhe confere o encanto de novidade. A arte como domínio separado só foi possível, em todos os tempos, como arte burguesa. Até mesmo sua liberdade, entendida como negação da finalidade social, tal como esta se impõe através do mercado, permanece essencialmente ligada ao pressuposto da economia de mercado. ${ }^{6}$

Nesse mesmo sentido seguiu a análise de Fredric Jameson, em "Pós-modernismo ou a lógica cultural do capitalismo tardio", em que o autor revisita a modernidade na tentativa de atualizar a teoria frankfurtiana frente aos impasses do que se convencionou chamar de pósmodernidade. Após a reestruturação do sistema capitalista, da contrarrevolução neoliberal, do surgimento de novas tecnologias de comunicação e do consequente processo de trocas cada vez mais global - operados, pode-se dizer, a partir, sobretudo, da década de 80 - tem-se um alargamento do conceito de cultura bem como uma ampliação de seu papel nesta "sociedade do espetáculo", em que a imagem, segundo Guy Debord, é a forma derradeira do processo de reificação.

A análise de Jameson é oriunda do momento em que tais circuntâncias entram em constelação: sua inovação, em termos teóricos, pressupõe uma nova leitura das relações entre economia e cultura no capitalismo tardio - ou antes, pressupõe sua fusão. A diferenciação das esferas - base e superestrutura - parece, segundo nosso autor, desaparecer na fase da mercantilização avançada, de modo a não podermos nem mesmo descrever objetivamente as condições infra-estruturais pós-modernas. Todavia, como afirma Maria Elisa Cevasco, em prefácio a Cultura do dinheiro, "um marxista ortodoxo se referiria de imediato a seu 'culturalismo'. Como tantos outros pensadores pós-revolucionários, ele faz parte do marxismo ocidental e sua atuação se dá no âmbito intelectual (...)". ${ }^{7}$

Uma vez inserido no "centro irradiador da nova fase da velha ordem mundial, os Estados Unidos" ${ }^{8}$, é preciso observar as forças em jogo que movem a esfera de atuação de seu

percepção, sua degradação reflete para eles a necessidade objetiva contra a qual se crêem impotentes." Adorno e Horkheimer, "O conceito de esclarecimento". In: Dialética do Esclarecimento. Rio de Janeiro: Zahar, p. 49.

${ }^{6}$ Adorno e Horkheimer, "A indústria cultural: o esclarecimento como mistificação das massas". In: Dialética do Esclarecimento. Rio de Janeiro: Zahar, 1985, p. 147.

${ }^{7}$ CEVASCO, Maria Elisa. Prefácio a Cultura do dinheiro, p. 9.

${ }^{8}$ Idem, Ibidem, p. 10. 
pensamento, sendo elas mais abrangentes - o estado das coisas - ou em escala menor, o ambiente intelectual circunscrito às Universidades norte-americanas.

Sob essa ótica, o próprio estilo de Jameson oferece pistas dos dilemas sobre os quais ele se detém, e pode ser útil na compreensão tanto do autor como do momento histórico. Pode-se afimar que, nesse aspecto, nosso autor é, seguramente, um esteta. Contudo, para além da sua prosa, sua inovação teórica sobre a relação entre as forças sociais que atuam no capitalismo tardio é digna de nota, e atesta sua enorme contribuição à tradição crítica, especialmente na atmosfera americana "hostil à dialética". 


\section{Iniciação ao debate: reflexões sobre o modernismo, o pós-modernismo e a pós- modernidade}

Em ensaio intitulado "Jameson and Form”, Terry Eagleton tece suas considerações acerca do crítico literário e cultural americano Fredric Jameson. O autor é equiparado por Eagleton aos grandes nomes que compõem a fortuna crítica literária anglofônica, como Edmund Wilson, Kenneth Burke, Northrop Frye, William Empson e Paul de Man. Sua primeira obra de impacto aparece no cenário teórico em 1971, com a publicação de Marxismo e Forma, "que tem como escopo a legitimação do marxismo como teoria crítica". ${ }^{9}$ Nessa obra, Jameson passa em revista expoentes da tradição crítico-dialética: Adorno, Benjamin, Marcuse, Lukács e Sartre (objeto de sua dissertação de mestrado em 1961).

Dentre suas qualidades, Eagleton destaca sua versatilidade, sua erudição enciclopédica, seu brilhantismo imaginativo e energia intelectual, em um momento em que a crítica literária perde parte de seu prestígio e força frente à pressão material dos primórdios daquilo que se configuraria como a pós-modernidade: “ele é certamente um dos mais soberbos estilistas críticos em uma era sem estilo". ${ }^{10}$

Jameson se define "como um homem dos anos 50, formado em meio à estagnação política da era Eisenhower, momento em que a esquerda americana está reduzida ao maior silêncio". ${ }^{11}$ Pode-se dizer, ainda, que datam dessa mesma década as origens da lógica cultural do capitalismo tardio, cujos sintomas haviam sido postos em evidência por Adorno e Horkheimer já em 1947, no célebre ensaio "Indústria Cultural: o iluminismo como mistificação das massas". Nas palavras de Jameson,

Todos concordam que as diferentes pré-condições para uma nova 'estrutura de sentimento' já haviam sido dadas antes do momento em que se combinaram e se cristalizaram em um estilo relativamente homogêneo: porém, essa pré-história não está sincronizada com a econômica. (...) Culturalmente, no entanto, as pré-condições se encontram (com exceção da grande variedade de "experimentos" modernistas aberrantes que são depois reestruturados como predecessores) nas grandes transformações sociais e psicológicas dos anos 60 ,

\footnotetext{
${ }^{9}$ CEVASCO, Maria Elisa, COSTA, Iná Camargo. Prefácio a Pós-modernismo ou a lógica cultural do capitalismo tardio. São Paulo: Ática, 2007, p. 8.

${ }^{10}$ (tradução nossa) "(...) For he is surely one of the the most superb critical stylists in a largely styless age." EAGLETON, Terry. "Jameson and Form". In: New Left Review 59, setembro - outubro/2009, p. 123.

${ }^{11}$ CEVASCO, Maria Elisa, COSTA, Iná Camargo. Prefácio a Pós-modernismo ou a lógica cultural do capitalismo tardio. São Paulo: Ática, 2007, p. 8.
} 
que varreram do mapa tantas tradições no nível das mentalités. Desse modo, a preparação econômica do pós-modernismo, ou do capitalismo tardio, começou nos anos 50, depois que a falta de bens de consumo e de peças de reposição da época da guerra tinha sido solucionada e novos produtos e novas tecnologias (inclusive, é claro, a da mídia) puderam ser introduzidos. ${ }^{12}$

É, portanto, sobre alguém que atinge sua maturidade intelectual quando o espírito pósmoderno já está em gestação, que Eagleton discorre em seu artigo. Suas considerações sobre a forma de pensamento - e, consequentemente, estilo de escrita - de Jameson são de extrema relevância para a compreensão tanto do autor como do fenômeno em si mesmo (a pósmodernidade). Se, como afirma Eagleton, o estilo de Jameson é único e original e, ao mesmo tempo, uma espécie de reificação, como então explicar sua inserção naquilo que se convencionou chamar de crítica cultural marxista de tradição hegeliana? ${ }^{13}$ É nesse sentido, então, que argumentação de Eagleton recorre aos paradigmas do modernismo e suas formas de enfrentamento do mundo, na tentativa de encontrar as correspondências entre ambos bem como os princípios da prosa jamesoniana.

O culto do estilo individual, ao mesmo tempo desprovido de subjetivação (como atesta um Picasso) é, pode-se dizer, marca de uma parcela da produção artística dita moderna. Ao se posicionar contra a produção pautada na noção de expressão subjetiva do autor, em que se dá a máxima ênfase à noção de gênio, muitas das vanguardas heróicas do século XX tencionavam a superação da reificação pela própria reificação ou, nos termos de Adorno, por meio da "mímese do petrificado".

Conforme Christopher Butler, em livro sobre o assunto,

Many cubists used popular materials (wine glasses, sheet music, newspapers, and so on) as the basis for their painting, and so it is tempting to see La Ville [a painting of Fernand

\footnotetext{
${ }^{12}$ JAMESON, Fredric. Pós-modernismo ou a lógica cultural do capitalismo tardio. São Paulo: Ática, 2007, p. 23.

${ }^{13}$ Cabe destacar que a crítica cultural marxista, de tradição hegeliana, destaca-se pelo que ficou conhecido como crítica dialética. A análise dialética de um objeto ideológico procura unir duas realidades que são, a priori, independentes: o espírito e a matéria. Por meio da justaposição de obra e contexto, é possível demonstrar o conteúdo sócio-histórico em funcionamento na própria forma. O momento de verdade, genuinamente contido no objeto, é então liberado de seu conteúdo de não-verdade, contrapondo-se sua aspiração à universalidade com a realidade objetiva. Nas palavras do teórico Peter Bürger, "uma hermenêutica que não só se impõe o objetivo de mera legitimação de tradições, mas o exame racional de sua pretensão de validade converte-se em crítica da ideologia". BÜRGER, Peter. Teoria da Vanguarda. São Paulo: Cosac Naify, 2008, p. 23.
} 
Léger] as also mimicking the effects of a big publicity posters in the city. ${ }^{14}$

Vale ainda dizer que a idéia de indivíduo como sujeito criador é posta em xeque ora por meio da produção coletiva, ora, em ocasiões mais extremas - como o famoso caso do urinol -, por meio da recusa radical da produção per se.

Segue-se que a categoria essencial sobre a qual o projeto moderno é erguido, e que fundamenta a razão moderna (na concepção weberiana, razão orientada para fins), é a de Sujeito. Livre dos grilhões da teologia, e da desigualdade ontológica sanguínea, o homem moderno aspira ao domínio da natureza e de si mesmo; "o indivíduo ousa individualizar-se". Todavia, a reconciliação entre homem e natureza, no sentido de uma harmonia entre ambos, - a síntese dialética entre sujeito e objeto - tornou-se ideológica em decorrência do domínio de uma classe sobre a outra. As imensas possibilidades que a era moderna ofereceu foram subsumidas pela exploração da classe dominante, como aponta Marx em famoso trecho do Manifesto Comunista:

O maquinário, dotado do maravilhoso poder de amenizar e aperfeiçoar o trabalho, só faz, como se observa, sacrificá-lo e sobrecarregá-lo. As mais avançadas fontes de saúde, graças a uma misteriosa distorção, tornam-se fontes de penúria. As conquistas da arte parecem ter sido conseguidas com a perda do caráter. Na mesma instância em que a humanidade domina a natureza, o homem parece escravizar-se a outros homens ou à sua própria infâmia. Até a pura luz da ciência parece incapaz de brilhar senão no escuro pano de fundo da ignorância. Todas as invenções e progressos parecem dotar de vida intelectual às forças materiais, estupidificando a vida humana ao nível da força material. ${ }^{15}$

Retornando à linha argumentativa, Jameson conclui ainda em Marxismo e Forma, que "a própria marca da experiência moderna do mundo é, precisamente, que tal identidade [entre sujeito e objeto] é impossível, e que a primazia do sujeito é uma ilusão, que sujeito e mundo exterior não podem nunca encontrar tal identidade final ou redenção nas circunstâncias históricas atuais". ${ }^{16}$ A desintegração da adequação entre conceito e ser reflete a perda da unidade da

\footnotetext{
14 "Muitos cubistas usaram materiais populares (copos de vinho, partituras, jornais, etc.) como base para suas pinturas e, nessa medida, é tentador ver La ville (obra de Ferdnand Léger), ao mesmo tempo, imitando os efeitos de um grande poster publicitário encontrado na cidade." (tradução nossa) BUTLER, Christopher. Modernism: a very short introduction. New York: Oxford, 2010, p. 7.

${ }^{15}$ MARX, Karl. Manifesto Comunista. São Paulo: Boitempo, 2002, p. 44.

${ }^{16}$ JAMESON, Fredric. Marxismo e Forma. São Paulo: Hucitec, 1985, p. 45.
} 
experiência do sujeito no mundo. Em outras palavras, "a sociedade burguesa produz uma ruptura fatal entre o sujeito da sociedade civil na sua 'existência sensível, individual e imediata' e o 'homem artificial abstrato, homem como pessoa moral, alegórica' do estado político”. ${ }^{17}$ Como observou Theodor Adorno,

A persistência dessas contradições na realidade, entretanto, acabou comprometendo a solução espiritual: diante de uma vida desprovida de sentido, uma vida que se esgota na azáfama dos interesses concorrentes, uma vida que a experiência artística percebe como prosaica; diante de um mundo em que o destino dos homens individuais se cumpre na obediência a leis cegas, a arte cuja forma dá a impressão de falar em nome de uma humanidade realizada converte-se em mero palavrório. ${ }^{18}$

Na esteira de Marx, Adorno e Jameson, para Eagleton o modernismo como movimento estético emerge do colapso do sistema semiótico de um significante em consonância com determinadas convenções sociais. ${ }^{19}$ Emerge, em suma, como uma tentaiva de por a nu as contradições das idéias dominantes em sua não adequação com a experiência particular, concreta, real - do confronto entre a ordem liberal e o universalismo humanista burguês, e sua resultante: "o sujeito mutilado".

O modernismo ergue-se sobre a base de uma estética autônoma que atinge seu ápice no século XIX, com o esteticismo ${ }^{20}$, em um momento em que o estímulo sensível torna-se, por assim dizer, livre. ${ }^{21} \mathrm{O}$ surgimento do domínio social designado por arte, o "momento libertador" de sua total separação em relação ao sagrado - a função de culto, para Walter Benjamin - atesta, nas palavras de Peter Bürger em Teoria da Vanguarda, "o surgimento de uma esfera da percepção da realidade subtraída à coerção da racionalidade-voltada-para-os-fins, sendo, ao mesmo tempo, o processo de ideologização dessa esfera (idéia de gênio, etc.)". ${ }^{22}$ Nas palavras de Adorno, “essa separação da objetividade, própria da pintura moderna (...), esteve determinada

\footnotetext{
${ }^{17}$ EAGLETON, Terry. A ideologia da Estética. Rio de Janeiro: Zahar, 1993, p. 156, 235.

${ }^{18}$ ADORNO, Theodor W. Notas de Literatura I. São Paulo: Duas Cidades; Ed. 34, 2003, p. 82.

${ }^{19}$ EAGLETON, Terry. "Jameson and Form". In: New Left Review 59, setembro - outubro/2009, p. 128.

20 "No esteticismo (...) o deslocamento da práxis vital, que sempre caracterizou o modo de função da arte na sociedade burguesa, transforma-se, então, em seu conteúdo." BÜRGER, Peter. Teoria da Vanguarda. São Paulo: Cosac Naify, 2008, p. 103.

${ }^{21}$ Idem, Ibidem, p. 100.

${ }^{22}$ Idem, Ibidem, p. 92.
} 
por uma posição defensiva contra a mercadoria artística mecanizada, sobretudo contra a fotografia". ${ }^{23}$

No que diz respeito à gênese do processo, a categoria de autonomia da arte deve ser vista em sua estreita conexão com a o desdobramento da classe burguesa, que se completa apenas no século XVIII. Economicamente desenvolvida e fortalecida graças ao poder político alcançado, a tentativa empreendida passa a ser a conquista de uma autoridade "moral" de classe dominante, que se dá, por sua vez, pela via estética. Sobre esse assunto, vale transpor um trecho da tese de Eagleton, em A ideologia da Estética:

A última força de coesão da ordem social burguesa, em contraste com o aparato coercitivo do absolutismo, serão os hábitos, as devoções, os sentimentos e os afetos. (...) Contar com o sentimento como forma de coesão não é algo tão precário. (...) E isso equivale a dizer que o poder, neste regime, foi estetizado. Meu argumento, lato sensu, é de que a categoria do estético assume tal importância no pensamento moderno europeu porque falando de arte ela fala também dessas outras questões, que se encontram no centro da luta da classe média pela hegemonia política. A construção da noção moderna de estética é assim inseparável da construção das formas ideológicas dominantes da sociedade de classes moderna, e na verdade, de todo um novo formato de subjetividade apropriado a esta ordem social. [...] Se ela [a categoria de estética] oferece uma imagem generosa e utópica de reconciliação [...] ela também bloqueia e mistifica os movimentos políticos reais que historicamente visem esta reconciliação. ${ }^{24}$

Pois se o sentimento passa a ser a nova forma de coesão da sociedade moderna, então não é mero acaso Flaubert escrever, ainda no século XIX, a obra intitulada Educação Sentimental. Em complemento a isso, destaca Peter Bürger:

Apenas no século XVIII (...) surge uma estética como disciplina filosófica, na qual um novo conceito de arte autônoma é criado. Na estética filosófica, o resultado de um processo que durou séculos é conceitualizado, (...) a atividade artística é compreendida como uma atividade distinta de todas as demais. (...) Apenas com a constituição da estética como esfera autônoma do conhecimento filosófico é que surge o conceito de arte em consequência do qual a criação artística se

\footnotetext{
${ }^{23}$ ADORNO, Theodor. Filosofia da nova música. São Paulo: Perspectiva, 2011, p. 15.

${ }^{24}$ EAGLETON, Terry. A ideologia da Estética. Rio de Janeiro: Zahar, 1993, p.13, 22, 24.
} 
vê arrancada à totalidade vital [Lebenstotalität] das atividades sociais e com elas abstratamente se defronta. ${ }^{25}$

Bürger pretende demonstrar que a oposição entre sensibilidade e intelecto ${ }^{26}-\mathrm{e}$ o consequente descolamento do estético ${ }^{27}$ - é fruto de uma condição histórica, resultado do desligamento da arte do contexto da práxis vital ${ }^{28}$ sob a égide de uma sociedade pautada pela instrumentalização: "o estético concebido como uma esfera excluída do princípio da maximização do lucro que predomina em todas as esferas da vida". ${ }^{29}$

O nó górdio da questão se dá no fato de que somente uma arte descolada da realidade no que concerne ao seu efeito prático, direto, teria sido capaz de alcançar o estágio da autocrítica e promover, por sua vez, a crítica da sociedade que lhe servia de base. A tentativa das vanguardas foi a de reintroduzir a possibilidade de um efeito real, de organizar uma nova praxis vital por meio da via artística, e estabelecer, assim, uma solução para a dicotomia entre a experiência e o pensamento - sujeito e objeto, o indivíduo e a sociedade, realidade e idéia.

Para retomar o fio da argumentação, cabe destacar que é sob essa perspectiva de superação da dualidade da vida e do espírito que opera, segundo análise de Eagleton, a escrita de Jameson. ${ }^{30}$ Herdeiro tardio do "culto fetichista do estilo individual modernista", sua forma de pensamento seria, por tal motivo, igualmente, uma forma de reificação. No entanto, o esforço dialético de Jameson de unir as esferas cindidas da sensorialidade imediata e da reflexão conceitual acabou por criar um modo único e original de dissertar. Eagleton o caracteriza ainda

\footnotetext{
${ }^{25}$ Idem, Ibidem, p. 93.

26 Em complemento ao acima exposto, segundo outro pensador, Terry Eagleton, "a estética nasceu do reconhecimento de que o mundo da percepção e da experiência não pode ser simplesmente derivado de leis universais abstratas, mas requer seu discurso mais apropriado e manifesta, embora inferior, sua própria lógica interna. Como uma espécie de pensamento concreto, ou análogo sensual do conceito, a estética participa ao mesmo tempo do racional e do real, suspensa entre os dois (...)" EAGLETON, Terry. A ideologia da Estética. Rio de Janeiro: Zahar, 1993, p. 19.

27 "Tal como a opinião pública, a autonomia da arte é uma categoria da sociedade burguesa, que, a um só tempo, torna reconhecível e dissimula um desenvolvimento histórico real. (...) A autonomia é, por conseguinte, uma categoria ideológica no sentido estrito da palavra, que congrega um momento de verdade (descolamento da arte da práxis vital) e um momento de não-verdade (hipostasiar esse estado de coisas, produzidos historicamente, como 'essência' da arte.” BÜRGER, Peter. Teoria da Vanguarda. São Paulo: Cosac Naify, 2008, p. 82, 101.

${ }^{28}$ A praxis vital, na sociedade moderna, é baseada na produção, circulação e consumo das mercadorias, com vista à obtenção de lucro. Idem, Ibidem.

${ }^{29}$ Idem, Ibidem, p. 94.

30 "We shall see later how this stylistic achievement, in which the sensible and intelligible constantly play into one another, is also Jameson's view a solution to what he takes to be the central dilemma of modernism." "Nós veremos depois como a concepção desse estilo, em que sensível e inteligível constantemente brincam um com o outro, é também, na visão de Jameson, uma solução para o que ele pensa ser o dilema central do modernismo." (tradução nossa) EAGLETON, Terry. "Jameson and Form”. In: New Left Review 59, setembro - outubro/2009, p. 125.
} 
em termos de sua afinidade com a forma literária proustiana, capaz de dotar de um corpo sensual idéias rígidas, bem como de traduzir conceitos em imagens sugestivas e reveladoras. ${ }^{31}$

Os comentários do próprio Jameson acerca do método dialético, presentes em Marxismo e Forma, são esclarecedores:

(...) Pensar dialéticamente significa nada mais do que escrever frases dialéticas; (...) é a forma das próprias frases (...) que determina a escolha da matéria-prima. (...) E na medida em que o pensamento dialético caracteristicamente envolve uma conjunção de fenômenos opostos ou pelo menos conceitualmente díspares, pode-se propriamente dizer da frase dialética aquilo que os surrealistas disseram da imagem, a saber, que sua força cresce proporcionalmente à medida que as realidades ligadas são distantes e distintas umas das outras. ${ }^{32}$

Vale ressaltar que, para Eagleton, Jameson parece não estar interessado em uma análise lógica rigorosa, e um dos seus pontos fracos consistiria em não saber, muitas vezes, o momento de parar. Sua "ânsia fáustica" de dar conta da totalidade faz com que ele traga "quase todo tipo de material" para dentro do corpo do texto. Sendo assim, seria possível classificar sua prosa como "européia" e moderna, no tocante ao culto do individual e à construção formal segundo a imagética proustiana, e pós-moderna em relação à pluralidade dos tópicos abordados e justapostos, que Eagleton considera ser de origem "americana". ${ }^{33}$ Afinal de contas, "existe uma ligação profunda entre as questões da epistemologia e as da História política". ${ }^{34}$

Ainda nesse sentido, seria pertinente explicitar a dívida da forma jamesoniana para com o programa filosófico de Adorno. Para este, a tarefa da filosofia não seria demonstrar a existência de sentido do mundo, por meio da busca da totalidade na pressuposição da harmonia social, embora Adorno ainda considere o problema da Verdade como necessário e incondicional para o pensamento. Na apreensão do real, Adorno lança mão da dialética hegeliana, e, desse modo, não

\footnotetext{
${ }^{31}$ Um exemplo claro desse modus operandi do nosso autor pode ser encontrado em trecho citado por Perry Anderson, no qual Jameson discorre sobre o retorno da estética da beleza na pós-modernidade (esvaziada), em comparação à utilização da Beleza do alto modernismo; "essas situações e momentos históricos nos quais a conquista da beleza é um violento ato político: a intensidade alucinatória da cor borrada no encardido torpor da rotina, o gosto doce-amargo do erótico num mundo de corpos brutalizados e exaustos". Jameson apud Anderson. ANDERSON, Perry. As Origens da pós-modernidade. Rio de Janeiro: Jorge Zahar, 1999, p. 128.

32 JAMESON, Fredric. Marxismo e Forma. São Paulo: Hucitec, 1985, p. 46, 47.

${ }^{33}$ EAGLETON, Terry. "Jameson and Form”. In: New Left Review 59, setembro - outubro/2009, p.126.

${ }^{34}$ EAGLETON, Terry. As Ilusões do pós-modernismo. Rio de Janeiro: Zahar, 1998, p. 22.
} 
garante nem a primazia do sujeito nem a do objeto: por meio da crítica imanente ${ }^{35}$, o conceito de mediação estabelece a relação entre dois termos. O conceito de mediação, por sua vez, opera por mímesis (a relação identificatória com o não idêntico) e faz apelo, igualmente, à negação determinada, para assim forçar a dimensão do conceito que foi recalcada ideologicamente. ${ }^{36}$

Com efeito, muito haveria a se dizer acerca dessas questões, mas a título introdutório é preciso insistir em um ponto: a filosofia adorniana não visa alargar a consciência, e sim, colocála em outra língua, a dialética (como modelo de intelecção do objeto), em que as contradições não são superadas em direção ao positivo; elas o são, de certa maneira, mas não como realização prática. Isso posto, a contradição revelaria o índice da verdade, em que as potencialidades dos conceitos ainda não foram realizadas:

Tanto no mosaico como a contemplação justapõem elementos isolados e heterogêneos, e nada manifesta com mais força o impacto transcendente, quer da imagem sagrada, quer da verdade. $\mathrm{O}$ valor desses fragmentos do pensamento é tanto maior quanto menor sua relação imediata com a concepção básica que thes corresponde, o brilho da representação depende desse valor da mesma forma que o brilho do mosaico depende da qualidade do esmalte. A relação entre o trabalho microscópico e a grandeza do todo plástico e intelectual demonstra que o conteúdo de verdade só pode ser captado pela mais exata das imersões nos pormenores do conteúdo. (...) Para que a verdade seja representada em sua unidade e em sua singularidade, a coerência dedutiva da ciência, exaustiva e sem lacunas, não é de nenhum modo necessária. E no entanto essa exaustividade sem lacunas é a única forma pela qual a lógica do sistema se relaciona com o conceito de verdade. ${ }^{37}$

\footnotetext{
${ }^{35}$ De acordo com Walter Benjamin, "essa investigação não fornece 'critérios' para o autor de resenhas. Nem a crítica nem os critérios de uma terminologia - o teste de uma teoria filosófica das ideias, na arte - podem constituirse segundo critério externo da comparação, mas de forma imanente, pelo desenvolvimento da linguagem formal da própria obra, que exterioriza seu conteúdo, ao preço de sua eficácia". BENJAMIN, Walter. Origem do Drama Barroco Alemão. São Paulo: Brasiliense, 1984, p. 66.

${ }^{36} \mathrm{Na}$ negação determinada, a relação que se estabelece é a seguinte: um dos termos (seja ele conceitual ou nãoconceitual) tem um limite interno à ele mesmo; quando entra em relação com um outro termo, algo desse termo oposto passa para o termo inicial. Dessa forma, pode-se dizer que há um movimento que se estabelece entre ambos, na medida em que pela aproximação dos extremos, é forçada a dimensão do conceito que foi recalcada ideologicamente. "A negação determinada rejeita as representações imperfeitas do absoluto, os ídolos, mas não como rigorismo, opondo-lhes a Idéia que elas não podem satisfazer. A dialética revela, ao contrário, toda imagem como uma forma de escrita. Ela ensina a ler em seus traços a confissão de sua falsidade, confissão essa que a priva de seu poder e o transfere para a verdade. Desse modo, a linguagem torna-se mais que um simples sistema de signos. Com o conceito de negação determinada, Hegel destacou um elemento que distingue o esclarecimento da desagragação positivista à qual ele o atribuiu. É verdade, que ele acabou por fazer um absoluto do resultado sabido do processo total da negação: a totalidade no sistema e na história, e que, ao fazer isso, infringiu a proibição e sucumbiu ele próprio à mitologia.” ADORNO, Theodor, HORKHEIMER, Max. Dialética do Esclarecimento. Rio de Janeiro: Zahar, 1985, p. 36-37.

${ }^{37}$ BENJAMIN, Walter. Origem do Drama Barroco Alemão. São Paulo: Brasiliense, 1984, p. 51, 55.
} 
A idéia $^{38}$ seria o modo de apresentação da verdade, em toda sua multiplicidade e descontinuidade: "a representação de uma idéia não pode de maneira alguma ser vista como bem-sucedida, enquanto o ciclo dos extremos nela não for virtualmente percorrido (...) E a estrutura é (...) monadológica. A idéia é mônada - isto significa, em suma, que cada idéia contém a imagem do mundo". ${ }^{39}$ Serve, nesse sentido, para iluminar aquilo que não se submete aos fenômenos, faz a mediação entre os opostos e ao fazê-lo, desvenda uma potencialidade que não se realizou e que fragiliza, põe em xeque, o realizado. Em outros termos: é a formalização da contradição, que procura apreender a distância entre o modelo (uma construção imaginativa, em que apenas a estrutura é cogniscível) e o objeto modelizado, para assim reconciliar-se com a História vista como processo. Na razão instrumental típica da sociedade administrada atesta-se a dominação predatória do não-conteitual (enquanto sensibilidade imediata). Faz-se necessário, dessa forma, lembrar à razão a sua potencialidade não realizada com base na crítica (descrição) do sofrimento social atual. ${ }^{40}$

O programa de Adorno é incompleto, fragmentado e contraditório para a consciência soberana, pautada pela intencionalidade. O materialismo de Adorno (diferente do materialismo histórico de Marx) procura interpretar o que não é posto intencionalmente pela estrutura da consciência do filósofo. Intenta, pois, liberar o sensível das raias do conceito, e alcançar a verdade, que só pode ser encontrada justamente por ser não intencional. É válido apontar, aqui, para a influência exercida por Walter Benjamin em Adorno, a partir da transposição de um trecho de Origem do Drama Barroco: "o objeto do saber, enquanto determinado pela intencionalidade do conceito, não é a verdade. A verdade é uma essência não-intencional,

\footnotetext{
${ }^{38}$ Segundo Benjamn, em Origem do Drama Baroco Alemão, "As ideias se relacionam com as coisas como as constelações com as estrelas. O que quer dizer, entre outras coisas, que as ideias não são nem os conceitos dessas coisas, nem suas leis. (...) Pois nelas, não é o semelhante que é absorvido, e sim o extremo que chega à sua síntese". BENJAMIN, Walter. Origem do Drama Barroco Alemão. São Paulo: Brasiliense, 1984, p. 56, 63.

${ }^{39}$ Idem, Ibidem, p. 69.

40 "Crer que a verdade da teoria é a mesma coisa que sua fecundidade é um erro. Muitas pessoas parecem, no entanto, admitir o contrário disso. Eles acham que a teoria tem tão pouca necessidade de encontrar aplicação no pensamento, que ela deveria antes dispensá-lo pura e simplesmente. Elas interpretam toda declaração equivocadamente no sentido de uma definitiva profissão de fé, imperativo ou tabu. Elas querem submeter-se à Idéia como se fora um Deus, ou atacá-la como se fora um ídolo. O que lhes falta, em face dela, é a liberdade. Mas é próprio da verdade o fato de que participamos dela enquanto sujeitos ativos". ADORNO, Theodor, HORKHEIMER, Max. Dialética do Esclarecimento. Rio de Janeiro: Zahar, 1985, p. 228.
} 
formada por idéias. O procedimento próprio à verdade não é portanto uma intenção voltada para o saber, mas uma absorção total nela, e uma dissolução. A verdade é a morte da intenção". ${ }^{41}$

$\mathrm{Na}$ categoria de sujeito, tida como modelo de organização da experiência da modernidade, está implícita uma determinação de unidade, em que a relação com o não-idêntico torna-se fonte de sofrimento: "uma coisa seria ao mesmo tempo ela mesma e outra coisa diferente dela, idêntica e não idêntica" ${ }^{42}$. No processo de construção do "eu" moderno o caráter fixo da identidade requerido fez com que a diferença fosse recalcada e denegada; no entanto, para Adorno, não há essa primazia do sujeito e existe certa opacidade do objeto da experiência que é interno a esse sujeito: “o osbcuro não é o puro ser em si, segundo se diz em passagens como a já citada Estética hegeliana. Trata-se, antes, de aplicar à arte a teoria da fenomenologia do espírito, para a qual todo imediatismo é já em si mesmo um produto da autoridade”. ${ }^{43}$

Em última instância, o preço a ser pago pela constituição do eu moderno foi o extermínio do que não se submeteu a sua lógica - "a plenitude perfeita da liberdade espiritual coincide com a castração do espírito". ${ }^{44}$ Em suma: "o obscuro que com o progresso do espírito recebe sempre novos ataques, renovou-se até aqui num aspecto diferente, graças à pressão que o espírito autoritário exerce na natureza interior do homem e na natureza exterior à ele". ${ }^{45} \mathrm{O}$ sujeito que não mais queria ser nem sangue, nem corpo ficou impedido de ter uma real experiência de alteridade e de não-identidade.

Isso nos coloca diante de uma questão de método. Ora, para Adorno, a "filosofia oficial serve à ciência", que "tem por função estocar fatos e conexões funcionais nas maiores quantidades possíveis" a fim de "possibilitar às diversas indústrias descobrir prontamente a mercadoria intelectual desejada na especificação desejada". A filosofia crítica não poderia, por assim dizer, mimetizar a linguagem do senso comum colonizada por categorias-esquemas:

Se a opinião pública atingiu um estado em que o pensamento inevitavelmente se converte em mercadoria e alinguagem em seu encarecimento, então a tentativa de pôr a nu semelhante depravação tem de recusar as convenções linguísticas e conceituais em vigor, antes que suas consequências para a história universal frustrem completamente essa tentativa. (...) Ao tomar consciência da própria culpa, o pensamento se vê

${ }^{41}$ BENJAMIN, Walter. Origem do Drama Barroco Alemão. São Paulo: Brasiliense, 1984, p. 58.

${ }^{42}$ Idem, Ibidem, p. 29.

${ }^{43}$ ADORNO, Theodor. Filosofia da nova música. São Paulo: Perspectiva, 2011, p. 22.

${ }^{44}$ Idem, Ibidem, p. 26.

${ }^{45}$ Idem, Ibidem, p. 22. 
por isso privado não só do uso da linguagem conceitual científica e quotidiana, mas igualmente da linguagem da oposição. (...) A falsa clareza é apenas a outra expressão do mito. ${ }^{46}$

Nos termos do filósofo, ainda, - e aqui ele segue Hegel - a arte tem o poder não apenas de ser agradável, de gerar o prazer em si mesmo, mas possibilita igualmente o "desdobramento da verdade"; no entanto, "o tratamento da arte se refere à arte e não aos conceitos de estilo, por mais contatos que tenham com ele". E, cabe destacar que, para Adorno, "as reflexões sobre o desdobramento da verdade na objetividade estética limitam-se unicamente à vanguarda, que está excluída da cultura oficial", e seguramente da indústria cultural. ${ }^{47}$

No que tange à forma da escrita de Jameson, novamente, vale notar que "movimento onívoro" de sua prosa admite posições muitas vezes divergentes, o que abre espaço para uma má compreensão de seu pensamento:

(...) Discutir os formalismos, os pós-estruturalismos e pósmodernismos não o torna um deles, mas a incorporação dessas posições como parte da discussão acaba tendo um efeito talvez indesejado que é o de permitir que reverberem e interfiram na exposição. (...) Afinal, perguntam os mais afoitos, Jameson é a favor ou contra essas manifestações? A resposta é, é claro, nem uma coisa nem outra (...). ${ }^{48}$

A fim de historicizar seu método, Eagleton aponta para os dilemas com os quais ele se detém. Com efeito, sua escrita é alegórica do zeitgeist pós-moderno em dois aspectos: primeiro, na tentativa de dar uma significação a um conteúdo de uma pós-modernidade tida como amorfa; depois, ao traduzir incessantemente conceitos em imagens, o estilo de Jameson tem como mérito mimetizar a abundância de material em sua quase exaustiva profusão, típica da sociedade do espetáculo. A justificativa para tal procedimento pode ser encontrada nas palavras do próprio Jameson:

(...) A alegoria é precisamente o modo predominante de expressão de um mundo no qual as coisas, não importa por que motivo, divorciaram-se completamente dos significados, do espírito, da genuína existência humana. ${ }^{49}$

\footnotetext{
${ }^{46}$ ADORNO, Theodor, HORKHEIMER, Max. Dialética do Esclarecimento. Rio de Janeiro: Zahar, 1985, p. 12, 14.

${ }^{47}$ ADORNO, Theodor. Filosofia da nova música. São Paulo: Perspectiva, 2011, p. 13, 14, 19.

${ }^{48}$ CEVASCO, Maria Elisa, COSTA, Iná Camargo. Prefácio à Pós-modernismo ou a lógica cultural do capitalismo tardio. São Paulo: Ática, 2007, p. 9.

${ }^{49}$ JAMESON, Fredric. Marxismo e Forma. São Paulo: Hucitec, 1985, p. 61
} 
Eagleton endossa a tese de que nosso autor é, em certos aspectos, um pós-moderno na medida em que considera seu estilo como uma renúncia à "tirania da subjetividade". Ainda que essa característica possa ser encontrada nos primórdios da modernidade, na poesia de um Baudelaire ${ }^{50}$, por exemplo, e tenha sido aprofundada por algumas correntes modernas, como na técnica da escrita automática praticada pelos surrealistas, é na pós-modernidade que tal característica atinge seu ponto culminante e, pode-se dizer, emerge como categoria fundamental dessa era. A problemática gira em torno, então, da busca de ir além - ou superar - o "culto moderno do estilo fetichista" sem cair no vazio "branco e anônimo pós-moderno":

To put in other terms, (though not ones used by Jameson himself): the vivid sensory of fragment or highly wrought style of modernism are resistances to reification - to a world of impersonal, determining forces - but they are also reifications in their own right. ${ }^{51}$

No horizonte de Jameson está, por assim dizer, a idéia de que um subjetivismo impressionista é apenas a outra face de uma espécie de positivismo - o mito dos fatos -, em que a realidade aparece como fixa e inerte - e nesse sentido, sem o movimento típico da dialética. Para Eagleton, o estilo de Jameson oferece uma verdadeira solução para o "dilema do pensamento", na medida em que é, ao mesmo tempo, "affective and impersonal", e tenta, pela síntese, superar tal dicotomia.

É válido, aqui, transpor um trecho de Marxismo e Forma, em relação à dialética negativa de Adorno, a fim de suscitar uma maior compreensão do pensamento jamesoniano:

Todavia, se essa síntese final para a qual se move o pensamento dialético acaba sendo inatingível, não se deve pensar que qualquer dos termos dessa síntese, qualquer dos dois opostos conceituais que são o sujeito e o objeto, seja

\footnotetext{
${ }^{50}$ Sua poesia, assinala Benjamin, "implica algo notável: a emancipação com respeito às vivências. (...) A experiência do choque é uma das que se tornaram determinantes para a estrutura de Baudelaire. (...) [Há] uma íntima relação existente em Baudelaire entre a imagem do choque e o contato com as massas urbanas. (...) Não se pode pensar em nenhuma classe, em nenhuma forma de coletivo estruturado. Não se trata de outra coisa senão de uma multidão amorfa de passantes (...) Essa multidão (...) está impressa em seu processo de criação como uma imagem oculta (...)" BENJAMIN, Walter. Charles Baudelaire, um lírico no auge no capitalismo. São Paulo: Brasiliense, 1989, p. 110, 112, 113.

51 "Para colocar em outros termos (embora não os utilizados pelo próprio Jameson): a imediaticidade sensorial do fragmento ou o caráter de constructo do modernismo são resistências à reificação - para um mundo impessoal, de forças determinantes - mas são também, à sua própria maneira, espécies de reificação." (tradução nossa) EAGLETON, Terry. "Jameson and Form”. In: New Left Review 59, setembro - outubro/2009, p. 131.
} 
necessariamente mais satisfatório isoladamente. $\mathrm{O}$ objeto considerado em si mesmo, o mundo tomado como conteúdo diretamente acessível, resulta nas ilusões do empirismo positivista simplista, ou num pensamento acadêmico que, erroneamente, toma suas próprias categorias conceituais por partes sólidas e pedaços do mundo real. Do mesmo modo, o refúgio exclusivo no sujeito resulta no que é para Adorno o idealismo subjetivo heideggeriano, uma espécie de historicidade a-histórica, uma mística da ansiedade, da morte e do destino individual sem nenhum conteúdo genuíno. Assim, a dialética negativa não tem outra escolha senão afirmar a noção e o valor de uma síntese final, ao mesmo tempo negando sua possibilidade e realidade em qualquer caso concreto colocado diante dela. ${ }^{52}$

Segue-se que a aporia gerada pela impossibilidade de chegar a uma síntese final entre o mundo sensível da experiência concreta e ordinária e as Idéias (ou Conceitos) obrigou o pensamento dialético a estabelecer meios pelos quais fosse possível alcançar o pensamento genuíno fora da trama simbólica da ideologia dominante: “a força histórica, a 'fúria do eclipse', impede esteticamente o compromisso ou a conciliação, que está aqui tão irremediavelmente condenado quanto no terreno político". ${ }^{53}$

De todo modo, assinala Eagleton, um "fetichismo do estilo deve ser claramente evitado" no que concerne à prosa de Jameson. Porém, é possível detectar algo do tipo como "uma má espécie de anonimato" em sua escrita, quando o sensorial que ele busca elevar ao nível do pensamento acaba por se perder no movimento incessante de suas sentenças. Nessa chave, cabe transcrever um trecho de Pós-modernismo ou a lógica cultural do capitalismo tardio, em que Jameson analisa o quadro de Edvard Munch, O grito, e onde essa modalidade apontada por Eagleton parece estar em funcionamento:

\footnotetext{
52 JAMESON, Fredric. Marxismo e Forma. São Paulo: Hucitec, 1985, p. 49.

${ }^{53}$ ADORNO, Theodor. Filosofia da nova música. São Paulo: Perspectiva, 2011, p. 16.
} 
which sonorous vibration becomes ultimately visible, as on the surface of a sheet of water - in an infinite regress which fans out from the sufferer to become the very geography of an universe in which pain itself now speaks and vibrates through the material sunset and the landscape. The visible world now becomes the wall of the monad on which this "scream running through nature" (Munch's words) is recorded and transcribed: one thinks of that character of Lautréamont who, growing up inside a sealed and silent membrane, on sight of the monstrousness of the deity, ruptures it with its own scream and thereby rejoins the world of sound and suffering. ${ }^{54}$

Em sua defesa, pode-se dizer que trata-se de uma necessidade do objeto; a urgência do material pós-moderno - fluido, plural, aleatório, heterogêneo -, bem como a "indiferença em relação ao afeto" oferecem algumas pistas para a compreensão da solução formal encontrada por nosso autor. Um certo prazer pela própria prosa que, no entanto, pode perder seu compromisso com o caráter didático e transmissão do conhecimento.

Com o propósito de inserir Jameson no campo do marxismo ocidental, Perry Anderson, em As origens da pós-modernidade, aponta para o que "de melhor" ele absorveu dos principais expoentes dessa tradição, em uma espécie de jogo pós-moderno:

De Lukács tirou Jameson seu compromisso com a periodização e o fascínio pela narrativa; de Bloch, um respeito pelas esperanças e sonhos escondidos num empanado mundo objetivo; de Sartre, uma excepcional fluência com as texturas da experiência imediata; de Lefebvre, a curiosidade pelo espaço urbano; de Marcuse, a investigação da pista do consumo high-tech; de Althusser, uma concepção positiva da ideologia como um imaginário social necessário; de Adorno, a

\footnotetext{
${ }^{54}$ JAMESON, Fredric. Postmodernism, or The Cultural Logic of Late Capitalism. In: The Jameson Reader. Malden: Blackwell publishing, 2005, p. 199. "Voltando, agora, pela última vez, ao quadro de Munch, parece evidente que $O$ grito, de forma sutil mas elaborada, rompe sua própria estética da expressão, ao mesmo tempo mantendo-se sempre preso a ela. Seu conteúdo gestual já assinala seu fracasso, uma vez que o domínio do sonoro, o grito, a pura vibração da garganta humana, é incompatível com seu meio (algo assinalado no interior da obra pelo fato de o homúnculo não ter orelhas). Entretanto, o grito ausente como que retorna em uma dialética de curvas e espirais, aproximando-se gradualmente da experiência ainda mais ausente da solidão atroz e da ansiedade que o próprio grito deveria "expressar". Tais curvas se inserem na superfície do quadro, na forma dos grandes círculos concêntricos nos quais a vibração sonora torna-se, em última análise, visível, como na superfície de um lençol de água, em retrocesso infinito, que se abre a partir do sofredor para se tornar a própria geografia de um universo no qual a dor agora fala e vibra, no pôr-do-sol e na paisagem. O mundo visível transforma-se, então, no muro que cerca a mônada, no qual esse "grito que ecoa na natureza", nas palavras de Munch, é registrado e transcrito: pensamos aqui naquela personagem de Lautréamont que, tendo sido criada dentro de uma membrana selada e silenciosa, rompe-a com seu próprio grito ao vislumbrar a monstruosidade da divindade e, desse modo, junta-se de novo ao mundo do som e do sofrimento." JAMESON, Fredric. Pós-modernismo ou a lógica cultural do capitalismo tardio. São Paulo: Ática, 2007, p. 41-42.
} 
ambição de representar a totalidade do seu objeto como sendo apenas uma "composição metafórica". ${ }^{55}$

Entretanto, segue Anderson, "tais elementos não jazem inertes numa combinação forçada", que são absorvidos "sem esforço", em um "estilo de instigante esplendor". Em consonância com Eagleton, ele constata que os ritmos de sua sintaxe, “complexa e flexível (...) permitem a absorção de variadas fontes na própria teoria" (o caráter americano e plural da prosa jamesoniana, quando mimetiza a intensa profusão de material da sociedade do capitalismo tardio), enquanto "as súbitas eclosões de intensidade metafórica, saltos e floreados estimulantes com um intenso brilho todo seu, são como emblemas dos vastos movimentos diagonais, mais próximos de uma inteligência poética que analítica (...)" ${ }^{56}$ : a imagética proustiana assinalada igualmente por Eagleton.

Sob esse paradigma, a obra de Jameson difere da tradição que lhe dá respaldo. Muito da análise da Escola de Frankfurt, uma das principais representantes do marxismo ocidental no século XX, "foi atraída para a estética como consolação involuntária pelos impasses políticos e econômicos". Sendo assim, afastou-se de uma análise da cultura moderna integrada numa teoria maior sobre o desenvolvimento econômico, e permaneceu "num ângulo destacado e especializado em relação ao movimento mais amplo da sociedade: acusável mesmo de certo idealismo do ponto de vista de um marxismo clássico". ${ }^{57}$ Idealismo este que por vezes representou aparente complexidade formal aliada a um diagnóstico um tanto quanto anêmico. Segundo Anderson, ainda, a abordagem da "lógica cultural do capitalismo tardio" oferece uma visão mais abrangente, que dá conta de retratar as transformações da forma social pós-moderna na sua totalidade, ao atestar não somente o caráter industrial que a permeia, mas ainda sua função estruturante de valoração do capital e desrealização do real, em um momento histórico "em que a realidade se apresenta para nós na sociedade do espetáculo". ${ }^{58}$

\footnotetext{
${ }^{55}$ ANDERSON, Perry. As origens da pós-modernidade. Rio de Janeiro: Jorge Zahar, 1999, p. 84.

${ }^{56}$ Idem, Ibidem, p. 85.

${ }^{57}$ Idem, Ibidem, p. 84.

${ }^{58}$ EAGLETON, Terry. As Ilusões do pós-modernismo. Rio de Janeiro: Zahar, 1998, p. 23.
} 
$* * * * *$

Em Pós-modernismo ou a lógica cultural do capitalismo tardio é possível encontrar, ao que parece, o motivo da falência da estética da expressão, em voga nos primórdios do movimento moderno. Seu desuso se dá em decorrência do esvaziamento, na pós-modernidade, da categoria de sujeito, fenômeno descrito por Fredric Jameson como esmaecimento dos afetos: "a expressão requer a categoria da mônada individual". ${ }^{59} \mathrm{O}$ denominador comum às transformações vislumbradas pelo autor acerca dessa era parece ser a falta de profundidade, e, dentre elas, a profundidade das emoções e laços afetivos: "um novo tipo de achatamento ou de falta de profundidade, um novo tipo de superficialidade no sentido mais literal (...)". ${ }^{60}$

De modo sucinto, segue o autor, "o próprio conceito de expressão pressupõe uma separação no interior do sujeito e, também, toda uma metafísica do dentro e fora, da dor sem palavras no interior da mônada (...)" ${ }^{61}$, agora substituído por certa indiferença ao sofrimento. Nesse quadro, os antigos sintomas psíquicos típicos do ordenamento social do capitalismo clássico e imperialista, como a histeria e ansiedade, são deslocados para a esquizofrenia e a depressão.

Nesse ponto, talvez fosse possível apontar novamente para a herança adorniana no pensamento de Jameson. A questão central que baliza a experiência filosófica de Theodor Adorno, do início ao fim, “(...) não será outra coisa que uma complexa teoria do sujeito que procura desdobrar suas consequências nos campos da reflexão sobre a teoria do conhecimento, a estética, a moral e a teoria social". Cabe ainda destacar que "que toda sua filosofia é a elaboração contínua e rigorosa das potencialidades abertas pelas expectativas vanguardistas da estética musical", a partir das experiências da Segunda Escola de Viena, as quais haviam produzido condições para que fosse concebido um pensar renovado acerca das categorias de sujeito e razão, por meio da mudança de ênfase da identidade para a diferença. Em suma: “(...) por meio da estética, Adorno encontrara as bases para pensar um conceito de sujeito não mais vinculado ao

\footnotetext{
${ }^{59}$ JAMESON, Fredric. Pós-modernismo ou a lógica cultural do capitalismo tardio. São Paulo: Ática, 2007, p. 43.

${ }^{60}$ Idem, Ibidem, p. 35.

${ }^{61}$ Idem, Ibidem, p. 39.
} 
primado da identidade, (...) unidade, e autodeterminação". ${ }^{62}$ Também por meio da estética, um perigoso flerte com o idealismo - embora dialético, ainda idealismo.

De fato, elevar a obra de arte à condição de saber parece ter uma raiz romântica oriunda de Schelling, para quem "a arte entra em ação quando o saber desampara os homens". ${ }^{63}$ Frente ao sofrimento social oriundo da falsa reconciliação (a unidade da coletividade e dominação ${ }^{64}$ ), na incongruência do conceito e da realidade, "pertence ao sentido da obra de arte, da aparência estética, ser aquilo em que se converteu, na magia do primitivo, o novo e terrível: a manifestação do todo no particular". ${ }^{65}$

Jameson inicia sua exposição a partir da leitura de dois quadros que tem por "objeto de representação" um mesmo conteúdo: sapatos. O primeiro, Um par de botas, de Vincent Van Gogh, é nas suas palavras um "trabalho canônico das artes visuais do alto modernismo". O segundo, Diamond dust shoes, de Andy Warhol, é uma "obra (...) realmente centrada em torno da mercantilização". ${ }^{66}$

Com relação à obra de Van Gogh, duas alternativas de interpretação são elencadas: a de que a explosão de cores vivas para figurar o universo opaco de um camponês seria uma espécie de compensação utópica para o campo visual (agora autônomo e fragmentado pela divisão do trabalho no interior do capital ${ }^{67}$ ), numa tentativa de domínio deste "sentido supremo"; uma outra, heideggeriana, de que a obra de arte emerge "na fratura entre a terra e o mundo, ou entre o que prefiro traduzir como a ausência de sentido na materialidade do corpo e da natureza e a doação de sentido na história e no social". ${ }^{68} \mathrm{O}$ que ambas tem em comum, pode-se dizer, é o modo de interpretação hermenêutica, em que "a obra em sua forma objetal inerte, é tomada como

\footnotetext{
${ }^{62}$ SAFATLE, Vladimir. "Theodor Adorno: a unidade de uma experiência filosófica plural.” In: Pensamento Alemão no século XX: grandes protagonistas e recepção das obras no Brasil, volume I. Jorge de Almeida e Wolfgang Bader (org.). São Paulo: Cosac naify, 2009, p. 167, 173.

${ }^{63}$ ADORNO, Theodor, HORKHEIMER, Max. Dialética do Esclarecimento. Rio de Janeiro: Zahar, 1985, p. 32.

${ }^{64}$ Idem, Ibidem, p. 35.

${ }^{65}$ Idem, Ibidem, p. 32.

${ }^{66}$ Idem, Ibidem, p. 35.

67 “(...) A visão, o visual, o olho - o que agora se recontitui para nós como um espaço semi-autônomo, parte de uma nova divisão do trabalho no interior do capital, uma nova fragmentação de um sensorial emergente que replica as especializações e divisões da vida capitalista, ao mesmo tempo que busca, precisamente em tal fragmentação, uma desesperada compensação utópica". Sendo assim, pode-se dizer que o descolamento do estético - já é em si mesmo fruto da divisão do trabalho - é acentuado, formando uma espécie de subdivisão interna em que o visual adquire predominância. Idem, Ibidem, p. 33.

${ }^{68}$ Idem, Ibidem, p. 34.
} 
uma indicação ou sintoma de uma realidade mais vasta que se coloca como sua verdade última". ${ }^{69}$

De acordo com essa perspectiva analítica, diz Jameson:

Andy Warhol's Diamond Shoes evidently no longer speaks to us with any of the immediacy of Van Gogh's footgear: indeed, I am tempted to say that it does not speak to us at all. On the level of the content, we have to do with what are now far more clearly fetishes, both in the Freudian and in the Marxian sense. (...) Here, however, we have a random collection of dead objects, hanging together on the canvas like so many turnips, as shorn of their earlier life-world as the pile of shoes left over from Auschwitz (...). ${ }^{70}$

A chave para compreensão dos motivos que amortecem a força crítica do quadro de Warhol, conforme nosso autor, situa-se na mudança estrutural do mundo dos objetos, e da sua inevitável relação com o sujeito. Jameson não chega a ampliar os parâmetros da discussão para o plano material em seus pormenores, no entanto, se recorrermos à História, é possível encontrar as causas responsáveis pelas mutações apontadas, de modo a reestabelecer o movimento dialético.

Faz-se necessário, portanto, retomar uma importante distinção proposta por Jameson no que concerne às "pré-condições" da pós-modernidade (cristalizadas, segundo ele, subsequentemente em um sistema funcional, de modo que seu reconhecimento só se dá $a$ posteriori, por meio da retroatividade). Culturalmente (leia-se: estruturas culturais e psicológicas), se encontram nos anos 60, materialmente, nos anos 50, com a reorganização das

\footnotetext{
${ }^{69}$ Conforme nosso autor, ainda, "o problema da interpretação é colocado pela própria natureza da textualidade: quando esta é predominantemente visual, parece não deixar espaço para uma interpretação à moda antiga e, quando é predominantemente temporal, em seu 'fluxo total' tampouco sobra tempo para a interpretação". Idem, Ibidem, p. 19,34 .

${ }^{70}$ JAMESON, Fredric. Postmodernism, or the Cultural Logic of Late Capitalism. In: The Jameson Reader. Malden: Blackwell publishing, 2005, p. 195. "Os Diamond dust shoes', de Andy Warhol, evidentemente, não nos falam com a mesma imeditiacidade dos sapatos de Van Gogh; de fato, sinto-me tentado a afirmar que não nos dizem absolutamente nada (...). No plano do conteúdo, temos que nos contentar com o que é agora muito mais claramente um fetiche, tanto no sentido freudiano quanto no marxista (...). Aqui, no entanto, temos que nos contentar com uma coleção aleatória de objetos sem vida, pendurados numa tela como se fossem nabos, tão desprovidos de sinais de sua vida anterior como uma pilha de sapatos que ficaram em Auschwitz (...). "JAMESON, Fredric. Pós-modernismo ou a lógica cultural do capitalismo tardio. São Paulo: Ática, 2007, p 35.
} 
relações internacionais, a descolonização e a emergência do sistema econômico mundial, seguindo as sugestões de Mandel. ${ }^{71}$

O momento em que ocorre essa "mutação mais fundamental" é denominado por Eric Hobsbawm como "os anos dourados" do capitalismo, e seu início coincide com a hipótese de periodização jamesoniana da pós-modernidade: o pós-segunda guerra mundial. Foi, portanto, um momento de crescimento econômico obtido graças, basicamente, à seguinte tríade: o modelo de produção de massa de Henry Ford ${ }^{72}$, o planejamento concebido por Keynes, calcado no ideal de pleno emprego e na intervenção estatal (em contraposição ao liberalismo da autoregulamentação do mercado), e o desenvolvimento tecnológico dos meios de comunicação (especialmente a televisão), responsáveis pela disseminação dos valores dessa sociedade movida pelo consumo.

No entanto, afirma Hobsbawm, "os benefícios materiais do crescimento levaram algum tempo para se fazer sentir. (...) Em suma, só na década de 1960 a Europa veio tomar sua prosperidade como coisa certa". ${ }^{73}$ Nesse sentido, se a "era de ouro democratizou o mercado", ela também impactou as mentes e os corações de quem viveu essa época. Na verdade, ela foi a base material da pós-modernidade que se firmaria anos depois, e do paradigma da sociedade do espetáculo.

Os chamados anos gloriosos de expansão da economia - que compreendem o período de 1945-1973 - não deram conta de superar os impasses inerentes ao capitalismo em si mesmo, o que impulsionou a criação de uma nova dinâmica das relações entre capital, trabalho e Estado, de modo a manter o sistema em funcionamento. Nas palavras do geógrafo marxista David Harvey,

\footnotetext{
${ }^{71}$ JAMESON, Fredric. Pós-modernismo ou a lógica cultural do capitalismo tardio. São Paulo: Ática, 2007, p. 23.

72 "Bens e serviços antes restritos a minorias eram agora produzidos para um mercado de massa (...). O que antes era um luxo tornou-se o padrão de conforto desejado, pelo menos nos países ricos: a geladeira, a lavaroupas automática, o telefone.” HOBSBAWM, Eric. Era dos extremos: o breve século XX, 1914-1991. São Paulo: Companhia das Letras, 1995, p. 259.

${ }^{73}$ Idem, Ibidem, p. 280.
}

A forte deflação de 1973-1975 indicou que as finanças do Estado estavam muito além dos recursos, criando uma profunda crise fiscal e de legitimação (...) A profunda recessão de 1973, exacerbada pelo choque do petróleo, evidentemente retirou o mundo capitalista do sufocante torpor da "estagflação" (estagnação da produção de bens e alta inflação de preços) e pôs em movimento um conjunto de processos que solaparam o compromisso fordista. Em consequência, as décadas de 70 e 80 foram um conturbado período de reestruturação econômica e de reajustamento social e político. No espaço social criado por todas essas oscilações e 
incertezas, uma série de novas experiências no domínio da organização industrial e da vida social e política começou a tomar forma. Essas experiências podem representar os primeiros ímpetos da passagem para um regime de acumulação inteiramente novo, associado com um sistema de regulamentação política e social bem distinta. A acumulação flexivel, como vou chamá-la, é marcada por um confronto direto com a rigidez do fordismo. (...) Ela também envolve um novo movimento que chamarei de "compressão do espaçotempo" no mundo capitalista - os horizontes temporais da tomada de decisões privada e pública se estreitaram, enquanto a comunicação via satélite e a queda dos custos de transporte possibilitaram cada vez mais a difusão imediata dessas decisões num espaço cada vez mais amplo e variado. (...) A estética relativamente estável do modernismo fordista cedeu lugar a todo o fermento, instabilidade e qualidades fugidias de uma estética pós-moderna que celebra a diferença, a efemeridade, o espetáculo, a moda e a mercantilização de formas culturais. ${ }^{74}$

É assim que, por exemplo, isso aparece em algumas manifestações culturais, analisadas por Jameson: ainda que a obra de Warhol dê conta de tematizar o problema da mercadoria e do fetichismo, e até mesmo da "morte do mundo da aparência", para Jameson, ela padece em termos formais. Sua técnica de "raio X decorativo" apenas intensifica o olhar já reificado e anestesiado do espectador, em um gesto inverso do que o quadro de Van Gogh promove; "não há, então, em Warhol, nenhum modo de completar o gesto hermenêutico e reintegrar essa miscelânea ao contexto vivido mais amplo do salão, ou do baile, do mundo da alta moda ou das revistas glamourosas". ${ }^{75}$ A realidade cinza e pálida do campesinato em Um par de botas é representada por meio da utilização de vivas cores (uma espécie de compensação utópica), enquanto o mundo brilhante e reluzente da mercadoria é retirado do Diamond dust shoes, restando o substrato do suporte fotográfico preto e branco, de modo a evitar qualquer contradição formal interna que pudesse ser projetada para fora da obra, e que seria o pontapé inicial da interpretação. ${ }^{76}$ Nesse

\footnotetext{
${ }^{74}$ HARVEY, David. Condição pós-moderna. São Paulo: Edições Loyola, 2002, p. 135, 140, 148.

${ }^{75}$ JAMESON, Fredric. Pós-modernismo ou a lógica cultural do capitalismo tardio. São Paulo: Ática, 2007, p. 35.

${ }^{76}$ Nas palavras de Perry Anderson: "In pictoral space, postmodern dephtlessness had found perfected expression in the enervated surfaces of Warhol's work, with their hypnotically empty after-images of the fashion page, the supermarket shelf, the television screen. Here Jameson was to stage the most bravura of all juxtapositions between high modern and postmodern, in a comparison of Van Gogh's peasent boots, emblems of earthly labour redeemed in a pyre of colour, and one of Warhol's sets of pumps, vitreous simulacra without tone or ground, suspended in an icy void". ANDERSON, Perry. The origins of Post-modernity. New York: Verso, 2006, p. 60. "No espaço pictórico, a profundidade pós-moderna encontrou expressão perfeita nas superfícies enervadas do trabalho de Warhol, com suas pós-imagens hipnoticamente vazias da página de moda, da prateleira do supermercado, da tela da televisão. Aqui Jameson foi representar a mais brilhante de todas as justaposições entre moderno e pós-moderno, em comparação
} 
sentido, esclarece Jameson, "penso que não se trata mais de uma questão de conteúdo, mas de uma mutação mais fundamental, tanto no próprio mundo dos objetos - agora transformados em um conjunto de textos ou simulacros - quanto na disposição do sujeito". ${ }^{77}$

No que tange ao sujeito, então, se o pós-modernismo assinala o fim do dilema do "dentro e do fora", essencial para a estética da expressão, o que essa nova era traz consigo é "o fim do ego burguês, ou da mônada, [que] sem dúvida traz consigo o fim das psicopatologias desse ego o que tenho chamado de esmaecimento dos afetos". ${ }^{78}$ A condição de possibilidade do sujeito centrado do capitalismo clássico parece ter sido a realidade desigual do novo e do arcaico capaz de dotar o indivíduo de uma perspectiva temporal, na medida em que ele ainda podia enxergar o passado bem como vislumbrar um futuro (havia, portanto, a preservação do "todo" e um sentido de continuidade histórica).

Sobre esse assunto, cabe destacar as considerações de Perry Anderson:

A primeira guerra mundial, destruindo os anciens régimes na Rússia, na Áustro-Hungria e na Alemanha e enfraquecendo os proprietários fundiários por toda parte, modificou mas não pôs fim a esse cenário. As classes altas européias e seu estilo de vida continuaram basicamente como antes; formas avançadas de organização industrial e consumo de massa - a idéia de Gramsci sobre o fordismo - continuaram em grande parte confinadas aos EUA; a revolução e a contra-revolução batalhavam do Vístula ao Ebro. Nessas condições, movimentos e formas de vanguarda de grande vigor continuaram a surgir - o Opojaz na Rússia, a Bauhaus na Alemanha, o surrealismo na França. A ruptura veio com a Segunda Guerra Mundial, cujas consequências esmagaram as velhas elites agrárias e seu estilo de vida na maior parte do continente, instituíram a democracia capitalista estável, padronizaram os bens de consumo duráveis no Ocidente e estriparam os ideais da Revolução no Leste. Com todas as forças que o incitaram liquidadas, o ímpeto modernista cedeu. Tinha vivido do assíncrono - o que no presente era passado e futuro - e morreu com a chegada do puramente contemporâneo: o estável e monótono Estado da ordem do pós-guerra. Daí em diante, a arte que ainda fosse radical estava normalmente fadada à integração comercial ou à cooptação institucional. ${ }^{79}$

com as botas de camponês de Van Gogh, emblemas de trabalho terrestre resgatados em uma pira de cor, e uma de série de sapatos de Warhol, simulacros vítreos sem tom ou chão, suspensos num vazio gelado." (tradução nossa)

77 JAMESON, Fredric. Pós-modernismo ou a lógica cultural do capitalismo tardio. São Paulo: Ática, 2007, p. 37.

${ }_{78}^{78}$ Idem, Ibidem, p. 43.

${ }^{79}$ ANDERSON, Perry. As origens da pós-modernidade. Rio de Janeiro: Jorge Zahar, 1999, p. 97. 
Além disso, vale destacar o papel da Natureza (notadamente a produção agrícola) - e do Inconsciente (atualmente bombardeado pela mídia e pela propaganda) ${ }^{80}$ - como os Outros da sociedade tecnocrata ocidental - remanescentes ainda presentes nos estágios do capitalismo de mercado e monopolista. É no capitalismo multinacional que a expansão da forma-mercadoria coloniza tais áreas de modo a não se poder mais falar em "algo fora do sistema". ${ }^{81}$

Cabe, aqui, outra vez, resgatar os comentários de Jameson em Marxismo e Forma:

A experiência é além disso socialmente condicionada, na medida em que depende dum certo ritmo de recorrências e similaridades nos acontecimentos que são propriamente culturais em origem. Assim, mesmo em Proust e Baudelaire, que viveram em sociedades relativamente fragmentadas, recursos ritualísticos, frequentemente inconscientes, são elementos primários na construção da forma: nós os reconhecemos na "vie anteriéure" e nas correspondências de Baudelaire, nas cerimônias de salão de Proust. E onde o escritor moderno tenta criar um presente perpétuo - como em Kafka - o mistério inerente aos eventos parece resultar não tanto de sua novidade como da impressão de que eles estavam simplesmente esquecidos, de que eles são em algum sentido "familiares", na significação inusitada que Baudelaire emprestou a esta palavra. Entretanto, à medida que a sociedade se deteriora cada vez mais, tais ritmos da experiência são cada vez menos encontráveis. ${ }^{82}$

Vale ainda transpor um trecho de Perry Anderson, a fim de amarrar o debate:

(...) Para Jameson, esta é uma condição geral da experiência pós-moderna, marcada por uma 'diminuição do afeto', que ocorre quando o velho eu amarrado começa a se desgastar. $\mathrm{O}$ resultado é uma nova superficialidade do sujeito (...). ${ }^{83}$

É necessário assinalar que nesta sociedade pós-moderna do "triunfo universal do capital" as antigas alternativas políticas ainda vigentes - embora enfraquecidas - até o final da década de oitenta perderam espaço tanto no plano real como no imaginário. A modernidade chega ao fim, como observa Jameson, "ao perder todo o contrário (...). O que outrora podia ser representado

\footnotetext{
${ }^{80}$ Jameson assinala que a Natureza e o Inconsciente como "enclaves pré-capitalistas" ofereciam, no modernismo, uma base para a efetividade crítica. JAMESON, Fredric. Pós-modernismo ou a lógica cultural do capitalismo tardio. São Paulo: Ática, 2007, p. 75.

${ }^{81}$ CEVASCO, Maria Elisa, COSTA, Iná Camargo. Prefácio à Pós-modernismo ou a lógica cultural do capitalismo tardio. São Paulo: Ática, 2007, p. 5.

${ }^{82}$ JAMESON, Fredric. Marxismo e Forma. São Paulo: Hucitec, 1985, p. 56.

${ }^{83}$ ANDERSON, Perry. As origens da pós-modernidade. Rio de Janeiro: Jorge Zahar, 1999, p. 68, 129.
} 
alternativamente pela alta sociedade ou pelo submundo, o nativo ou estrangeiro, some agora (...)". ${ }^{84}$ Isso significaria, entre outras coisas, que as antigas classes, nos moldes concebidos por Marx, assumiram uma nova feição, o que levou diversos autores a concluir que não mais existiam, como se o pluralismo dos grupos e a política de identidade fossem "reais" (apesar de conterem, sim, seus respectivos "conteúdos de verdade", como a conquista de direitos civis) e não parte da ideologia neoliberal (transformados em segmentos de mercadorias e nichos de mercado para o consumo).

No auge de sua militância, "o pós-modernismo emprestou a voz aos humilhados e insultados e, ao fazê-lo, ameaçou abalar ao extremo a autoridade dominante do sistema. E por causa disso quase podemos perdoar-lhes os excessos palmares", comenta Terry Eagleton. Seria de se esperar, segue o autor, "um surto de interesse nas margens e lacunas do sistema - naqueles pontos ambíguos, indeterminados em que seu poder parecia menos implacável, as margens obscuras por onde ele se foi consumido até o silêncio". ${ }^{85}$ Todavia, isso não equivale à sugestão da identidade entre o sistema e sua negação e o consequente "fim da história".

A pós-modernidade, então, para Jameson, emerge quando o processo de modernização “está completo e a natureza se foi para sempre. É um mundo mais completamente humano do que o anterior, mas é o mundo no qual a cultura se tornou uma verdadeira segunda "natureza" ${ }^{86}$, um mundo ainda em que a memória coletiva das antigas gerações foi substituída. A segunda natureza de que falava Walter Benjamin, em "A obra de arte na era da reprodutibilidade técnica", seria a adequação dos sentidos à nova forma de produção cultural reprodutível e, portanto, nãoaurática ${ }^{87}$, mais próxima e acessível. Entretanto, suas possibilidades emancipatórias, por assim

\footnotetext{
${ }^{84}$ Perry Anderson constata que a década de oitenta assistiu à derrota dos movimentos operários nas áreas centrais, que se viu enfraquecido, ainda, pela crescente descentralização da produçãõ e deslocamento dos investimentos para o setor de serviços e da informação, característicos da produção flexível. Idem, Ibidem, p. 108.

${ }^{85}$ EAGLETON, Terry. As Ilusões do pós-modernismo. Rio de Janeiro: Zahar, 1998, p. 12, 33.

${ }^{86}$ JAMESON, Fredric. Pós-modernismo ou a lógica cultural do capitalismo tardio. São Paulo: Ática, 2007, p. 13.

${ }^{87}$ Segundo Benjamin, "no interior de grandes períodos históricos, a forma de percepção das coletividades humanas se transforma ao mesmo tempo que seu modo de existência. O modo pelo qual se organiza a percepção humana, o meio em que ela se dá, não é apenas condicionado naturalmente, mas também historicamente. (...) se fosse possível compreender as transformações contemporâneas das faculdades perceptivas segundo a ótica do declínio da aura, as causas sociais dessas transformações se tornariam inteligíveis. Em suma, o que é aura? É uma figura singular, composta de elementos espaciais e temporais: a aparição única de uma coisa distante, por mais perto que ela esteja. (...) Graças a essa definição, é fácil identificar os fatores sociais específicos que condicionam o declínio atual da aura. Ele deriva de duas circunstâncias, estreitamente ligadas à crescente difusão e intensidade dos movimentos de massas. Fazer as coisas 'ficarem mais próximas' é uma preocupação tão apaixonada das massas modernas como sua tendência a superar o caráter único de todos os fatos através da reprodutibilidade". BENJAMIN, Walter. Magia e técnica, arte e política: ensaios sobre literatura e história da cultura. São Paulo: Brasiliense, 1994, p. 169,170.
} 
dizer, nas quais o filósofo alemão se apoiava na década de trinta não foram concretizadas, a despeito de uma ainda atual crença populista no potencial democrático da indústria cultural.

Uma vez identificado o "campo de força da pós-modernidade nas mudanças estruturais do capitalismo avançado e um difuso escalonamento das identidades sob elas", Jameson pôde apontar para o que seria o foco principal de seu ensaio, no terreno cultura. "Sua inovação aí foi tópica", ressalta Perry Anderson. Na medida em que não se concentrou na literatura ou na música (apesar de ter a arquitetura permanecido no centro de sua visão, como o locus privilegiado da manifestação pós-moderna ${ }^{88}$ ), não ficou restrito à análise de uma esfera específica, e sua obra teve o mérito de esboçar "um painel da época incomparavelmente mais rico e abrangente do que qualquer outro registro dessa cultura". ${ }^{89}$

A mutação na esfera da cultura a que se refere Fredric Jameson pode ser interpretada como uma enorme expansão de seu domínio, daquilo que Guy Debord chamou já em 1968 de "sociedade do espetáculo"; "um salto quantitativo no que Benjamin ainda denominava 'estetização' da realidade.” Assim, segue, “na cultura pós-moderna, a própria 'cultura' se tornou um produto, o mercado tornou-se seu próprio substituto. (...) O pós-moderno é o consumo da própria produção de mercadorias como processo (...) e isso é uma intensificação dialética da auto-referencialidade de toda cultura moderna, que tende a se voltar para si mesma e a designar sua própria produção cultural como seu conteúdo". ${ }^{90} \mathrm{O}$ modernismo, não obstante, oferecia, por meio de seus diferentes movimentos e protestos, uma crítica à forma-mercadoria e uma intenção

\footnotetext{
${ }^{88}$ Segundo Jameson, "é no âmbito da arquitetura que as modificações da produção estética são mais dramaticamente evidentes e seus problemas teóricos têm sido mais constantementes abordados e articulados; de fato, foi dos debates sobre arquitetura que minha concepção do pós-modernismo - como esboçada nas páginas seguintes - começou a emergir. De modo mais decisivo do que nas outras artes ou na mídia, na arquitetura as posições pós-modernistas são inseparáveis de uma crítica implacável ao alto modernismo arquitetônico (...). Aí, a crítica formal (da transformação do edifício em escultura virtual, típica do alto modernismo, ou em um "pato" monumental, segundo Robert Venturi) inclui uma reavaliação do urbanismo e da instituição estética. Nessa ótica, atribui-se ao alto modernismo a responsabilidade pela destruição da teia urbana da cidade tradicional e de sua antiga cultura da vizinhança (por meio da disjunção radical de seu contexto ambiental do novo edifício utópico do alto modernismo), ao mesmo tempo que o elitismo e o autoritarismo proféticos do movimento moderno são implacavelmente idenitifcados no gesto imperioso do Mestre carismático. (...) É bastante lógico, então, que o pós-modernismo em arquitetura se apresente como uma espécie de populismo estético (...)". JAMESON, Fredric. Pós-modernismo ou a lógica cultural do capitalismo tardio. São Paulo: Ática, 2007, p. 28.

${ }^{89}$ ANDERSON, Perry. As origens da pós-modernidade. Rio de Janeiro: Jorge Zahar, 1999, p. 69.

${ }^{90}$ JAMESON, Fredric. Pós-modernismo ou a lógica cultural do capitalismo tardio. São Paulo: Ática, 2007, p. 14, 69.
} 
de transcendê-la. Ao chegar à pós-modernidade, pode-se dizer que o sentimento suscitado em relação à indústria cultural descrita por Adorno e Horkheimer é o de nostalgia. ${ }^{91}$

Com efeito, o que ocorreu nesse "meio tempo" entre os experimentos modernistas e o pós-modernismo foi "a falsa superação da distância entre arte e vida. (...) $\mathrm{Na}$ sociedade do capitalismo tardio, intenções dos movimentos históricos de vanguarda são realizadas com sinais invertidos". ${ }^{92}$ A "primeira vítima" desse processo de expansão do estético foi o próprio modernismo. A canonização do que era um enfrentamento político no âmbito representacional agora eternizado como estilo - acabou por esvaziar a força crítica, neutralizar o efeito de choque e transformar as mais dissonantes formas de figuração em "velhos clássicos, que 'pesam na cabeça dos vivos como um pesadelo" 93, como afirmou Marx em 18 Brumário de Luis Bonaparte, a respeito da Revolução Francesa. Para Perry Anderson, "as lições do Marxismo Ocidental, como das clássicas vanguardas, deveriam ser aprendidas, mas seu tempo tinha passado - um período havia terminado". ${ }^{94}$

O "repúdio ideológico ou estético do centenário movimento modernista" por parte do pós-moderno na verdade põe em xeque a noção de telos da arte, "aquela segundo a qual cada obra genuinamente nova, de forma inesperada, ainda que lógica, superava sua predecessora (...)". ${ }^{95} \mathrm{O}$ expressionismo abstrato em pintura (para Adorno, na personificação de Pollock, "o último suspiro da arte"), o existencialismo em filosofia, as formas derradeiras da representação no romance, os filmes dos grandes auteurs ou a escola modernista na poesia são, para Jameson, “a floração final do impulso do alto modernismo". Enumerar ou classificar o que vem depois do "fim da arte" (ainda que não tenha havido sua total dissolução na filosofia, nos termos de Hegel), nesse sentido, se torna um movimento caótico, empírico e heterogêneo, dificuldade que se

\footnotetext{
${ }^{91}$ Para Perry Anderson, "nas condições atuais, o que outrora foram limitações idiossincráticas tornaram-se antídotos essenciais". A colocação expressa o sentimento de Jameson em relação à Adorno, e está presente em seu Late marxism. Dessa maneira, se antes a conjuntura esboçada sobre a indústria cultural em Dialética do Esclarecimento era tida como extremista e elitista, agora ela retorna como espécie de cura para o impasse estabelecido entre a euforia populista dos discursos sobre a cultura de massa e a realidade pós-moderna. ANDERSON, Perry. As origens da pós-modernidade. Rio de Janeiro: Jorge Zahar, 1999, p. 124-125.

${ }_{92}^{9}$ BÜRGER, Peter. Teoria da Vanguarda. São Paulo: Cosac Naify, 2008, p. 114.

${ }^{93}$ JAMESON, Fredric. Pós-modernismo ou a lógica cultural do capitalismo tardio. São Paulo: Ática, 2007, p. 30.

${ }^{94}$ (tradução nossa) "The lessons of Western Marxism, as of the classical avant-gardes, needed to be learnt, but their time was up - 'a period has ended”. ANDERSON, Perry. The origins of Post-modernity. New York: Verso, 2006, p. 70.

95 JAMESON, Fredric. Pós-modernismo ou a lógica cultural do capitalismo tardio. São Paulo: Ática, 2007, p. 15, 27.
} 
impõe, na realidade, a toda tentativa de teorização (leia-se: totalização) do pós-moderno, dadas suas características intrínsecas.

É preciso ressaltar que as vanguardas heróicas do período entre guerras objetivaram a superação da categoria obra antes mesmo da emergência do texto pós-moderno. Seu ataque operado na produção e na recepção - se deu por um motivo que estava para além da mera inovação ou ruptura com a tradição, na medida em que na obra de arte orgânica a recepção ocorre segundo uma concordância entre as partes e o todo, no que tange ao sentido. Sua rejeição, na obra não-orgânica, aponta para a impossibilidade de reconciliação do homem com a natureza - em última instância, da experiência com o conceito. ${ }^{96}$

No que concerne ao texto, é possível afirmar que sua ascensão é um fenômeno sintomático do ambiente pós-moderno; "mas isso causa tanta comoção entre as categorias da crítica quanto nas da criação", posto a ênfase celebratória da desconstrução e da multiplicidade. A disparidade e a incomensurabilidade fundamental entre texto e obra, segue nosso autor,

(...) Significa que selecionar textos exemplares e, através da análise, fazer com que estes suportem o peso universalizante de um particular representativo transforma-o, de novo, naquele fenômeno mais antigo, a obra, que não deveria mais existir no pós-moderno. Este é, por assim dizer, o princípio de Heisenberg do pós-modernismo, e o problema de mais difícil representação para qualquer comentarista solucionar, a não ser

\footnotetext{
${ }^{96}$ Nesse sentido, é a negação da síntese que pauta a criação vanguardista. A impressão unitária da obra de arte orgânica "procura tornar irreconhecível seu caráter de objeto produzido". As vanguardas, nesse aspecto, têm na montagem seu procedimento básico, uma vez que unem fragmentos da realidade e acabam por romper com a aparência de totalidade. O conceito de alegoria tal como formulado por Benjamin para analisar a dramaturgia barroca parece ser adequado para descrever o funcionamento dos produtos vanguardistas. Bürger desenvolve quatro aspectos em que a alegoria aparece como um procedimento recorrente na produção e na recepção das obras. No que concerne à esfera da produção, o alegorista "arranca um elemento à totalidade do contexto da vida. Ele o isola, priva-o de sua função". Sendo assim, e na medida em que é fragmento, não há a falsa aparência de totalidade. Ato contínuo, as partes isoladas são reagrupadas de modo a produzir um sentido que não dado originalmente. Quanto ao efeito estético, a alegoria é capaz de evocar a história como derrocada, decadência, por sua natureza de "protopaisagem petrificada". Vale ressaltar ainda que a atividade do alegorista enquanto produtor é vista por Benjamin como expressão da melancolia. Do ponto de vista da produção, a alegoria pode ser equiparada à categoria de montagem, uma vez que "a montagem pressupõe a fragmentação da realidade e descreve a fase da constituição da obra". Historicamente surgida no contexto do cubismo, não se confunde com a fotomontagem ou com a montagem cinematográfica, posto que ambas se tornam irreconhecíveis enquanto procedimento. No entanto, a heterogeneidade e emancipação das partes da obra de arte de vanguarda, ainda que tencionassem a superação da categoria de obra em si - pela negação da síntese e pelo choque - acabaram por ser absorvidas, na medida em que as partes não alcançaram um total descolamento do todo - e, desse modo, da própria categoria de obra. "A unidade absorveu a contradição”. BÜRGER, Peter. Teoria da Vanguarda. São Paulo: Cosac Naify, 2008, p. 141, 147, 148, 160.
} 
através de uma infindável projeção de slides, um "fluxo total" prolongado até o infinito. ${ }^{97}$

Ao retornar para a problemática do impacto do pós-moderno no indivíduo, Jameson afirma que a consequência formal para o processo de "esmaecimento do afeto", ou "desaparecimento do sujeito individual" é a inviabilidade da criação de um estilo pessoal genuíno (típico do modernismo), e a prática do pastiche: "o ecletismo do enfraquecido" 98. Diferente da paródia (apesar de seguirem o mesmo princípio - a imitação), o pastiche opera no registro da "neutralidade", posto ser concebido de forma não agressiva e sem a intenção de provocar um abalo na sensibilidade do espectador; ele apenas se desvia da norma da linguagem para depois reafirmá-la. ${ }^{99}$

A fonte para tal formulação, diz Anderson, está na crítica de Adorno acerca da música dodecafônica de Stravinsky (Filosofia da nova música), tida por ele como "ecletismo regressivo". No entanto, Jameson deu uma definição mais aguçada: "o pastiche é uma paródia branca", sem ímpeto satírico, dos estilos do passado. A citação dá lugar à incorporação. Disseminando-se da arquitetura para o cinema, da pintura para o rock, tornou-se a mais padronizada assinatura do pós-moderno". ${ }^{100}$

Na medida, então, que "os estilos modernistas se transformaram (...) nos códigos pósmodernistas", e com esse "apetite, historicamente original, por um mundo transformado em mera imagem de si próprio" ${ }^{101}$, os produtores culturais pós-modernos se voltam para o passado, chamado agora de "historicismo, a saber, a canibalização aleatória de todos os estilos (...), o jogo

\footnotetext{
${ }^{97}$ JAMESON, Fredric. Pós-modernismo ou a lógica cultural do capitalismo tardio. São Paulo: Ática, 2007, p. 21.

${ }^{98}$ ADORNO, Theodor. Filosofia da nova música. São Paulo: Perspectiva, 2011, p. 16.

${ }^{99}$ Jameson utiliza aqui a análise do "tipo de leitura imposto" por Ragtime, de Doctorow, para exemplificar a modalidade de "escrita branca" pós-moderna. A exclusão de uma interpretação social e histórica - e, consequentente da noção de passado - aparece na própria construção formal do romance, no efeito pretendido pela escolha do tempo verbal. Tal efeito seria o mesmo utilizado por Camus em L'étranger, obra em que há a predominância do passe composé, tempo que tem como principal função o relato de um evento particular, começado e acabado. Sua utilização sucessiva dá conta de mimetizar, por assim dizer, a efemeridade, ou uma série de eventos pontuais e desconexos, que simplesmente aconteceram, sem relação causal nem profundidade, e dessa maneira confere uma certa "banalidade" ao que é narrado. JAMESON, Fredric. Postmodernism, or The Cultural Logic of Late Capitalism. In: The Jameson Reader. Malden: Blackwell publishing, 2005, p. 207.

${ }^{100}$ ANDERSON, Perry. As origens da pós-modernidade. Rio de Janeiro: Jorge Zahar, 1999, p. $72-73$.

${ }^{101}$ JAMESON, Fredric. Pós-modernismo ou a lógica cultural do capitalismo tardio. São Paulo: Ática, 2007, p. 45.
} 
aleatório de alusões estilísticas". ${ }^{102}$ Sob essa perspectiva, pode-se dizer que o pastiche é a imitação daquilo que já está morto.

Segundo Jameson ainda, "a urgência desvairada da economia em produzir novas séries de produtos que cada vez mais pareçam novidades (de roupas a aviões), com um ritmo de turn over cada vez maior, atribui uma posição e uma função estrutural cada vez mais essenciais à inovação estética (...)". ${ }^{103}$

$\mathrm{O}$ "esmaecimento do afeto na cultura pós-moderna", segue, não significa "que todos os afetos, todo sentimento ou emoção, toda subjetividade, tenham desaparecido na imagem mais recente". ${ }^{104}$ A questão, na verdade, pode ser mais facilmente detectada no plano da figura humana, em que a superficialidade também é a marca principal. Se a tendência social geral exclui mais e mais o elemento humano pela sua reificação, então se torna evidente o desmoronamento da idéia de expressão.

Há outro aspecto ainda em que o pos-modernismo contribui para a dessensibilização do espírito contemporâneo; nossa vida cotidiana, "nossas experiências psíquicas, nossas linguagens culturais são hoje dominadas pela categoria de espaço e não pelas de tempo, como eram no período do alto modernismo". ${ }^{105} \mathrm{Na}$ era do satélite e da fibra ótica,

(...) O espacial comanda como nunca esse imaginário. A unificação eletrônica da Terra, instituindo a simultaneidade de eventos mundo afora como espetáculo diário, instalou uma geografia substituta nos recessos de cada consciência, enquanto as redes circundantes de capital multinacional que efetivamente dirigem o sistema ultrapassam a capacidade de qualquer percepção (...). O carregado senso do passado que caracteriza o modernismo já não existia - fosse como transpiração de tradições repressivas ou reservatório de sonhos frustrados - e desapareceu a intensa expectativa do futuro como possível cataclisma ou transfiguração - que caracterizam o modernismo. No máximo, apagando-se num perpétuo presente, os estilos e imagens retrô proliferam como substitutos do temporal. ${ }^{106}$

\footnotetext{
${ }^{102}$ Vale, aqui, aprofundar algumas considerações sobre este assunto. A tendência moderna da construção da obra de arte não orgânica, em que as partes não se subordinam ao todo (BÜRGER) calcada na montagem/colagem é acentuada na pós-modernidade a ponto de se tornar intrínseca à ela. Idem, Ibidem, p. 45.

${ }^{103}$ JAMESON, Fredric. Pós-modernismo ou a lógica cultural do capitalismo tardio. São Paulo: Ática, 2007, p. 30.

${ }^{104}$ Idem, Ibidem, p. 37.

${ }^{105}$ Idem, Ibidem, p. 43.

${ }^{106}$ ANDERSON, Perry. As origens da pós-modernidade. Rio de Janeiro: Jorge Zahar, 1999, p. 68.
} 
A categoria de tempo, por sua vez, implica historicidade, que resgata a memória, tanto individual como coletiva, e possibilita a expressão genuína. ${ }^{107}$ Sendo assim, o achatamento de perspectiva pós-moderno opera tanto em termos Históricos como do próprio Sujeito. Nesse sentido, encerra Anderson:

A vida psíquica torna-se debilitantemente acidentada e espasmódica, marcada por súbitas depressões e mudanças de humor que lembram algo da fragmentação esquizofrênica. Esse fluxo oscilante e hesitante impede tanto a catexia como a historicidade. Significativamente, às vacilações do investimento libidinal na vida privada correspondeu uma erosão dos marcadores de geração na memória pública, com as décadas que se seguiram aos anos 60 tendendo a nivelar-se numa seqüência desinteressante classificada sob o rol comum do pós-moderno. Mas se essa descontinuidade enfraquece o senso de diferença entre os períodos no nível social, seus efeitos estão longe de monótonos no nível individual. Aí, ao contrário, as polaridades vão da exaltação da "corrida às mercadorias", do eufórico entusiasmo do espectador ou consumidor, para a depressão no "vazio niilístico mais profundo do nosso ser", como prisioneiros de uma ordem que resiste a qualquer outro controle ou significado. ${ }^{108}$

A crise de historicidade como sintoma da pós-modernidade atesta a crise da temporalidade em geral: “é de se esperar que a nova lógica espacial do simulacro tenha um efeito significativo sobre o que se costumava chamar de tempo histórico" ${ }^{109}$ : a fronteira entre o vivido e o percebido ameaça esfumaçar-se. Ao acolher a fragmentação e a efemeridade no seio de seu projeto, em uma sociedade mediada pela imagem (cabe destacar as célebres palavras de Guy Debord acerca do assunto: "a imagem é a forma final da reificação" ${ }^{110}$ ), o pós-modernismo não tenta legitimar-se pela referência ao passado ${ }^{111}$, e "estamos condenados a buscar a História através de nossas próprias imagens pop e dos simulacros daquela história que continua para sempre fora de nosso alcance". Sobre o assunto, assinala igualmente Eric Hobsbawm,

\footnotetext{
${ }^{107}$ Walter Benjamin, em seu ensaio sobre Baudelaire, constata que "onde há experiência no sentido estrito do termo, entram em conjunção, na memória, certos conteúdos do passado individual com outros do passado coletivo. (...) As inquietações de nossa vida interior não têm, por natureza, este caráter irremediavelmente privado. Elas só o adquirem depois que as chances dos fatos exteriores se integrarem à nossa experiência. (...) [Baudelaire] também é ele um homem espoliado em sua experiência - um homem moderno." BENJAMIN, Walter. Obras escolhidas III Charles Baudelaire, um lírico no auge do capitalismo. São Paulo: Brasiliense, 1989, p. 106-107, 130.

${ }^{108}$ ANDERSON, Perry. As origens da pós-modernidade. Rio de Janeiro: Jorge Zahar, 1999, p. 69.

109 JAMESON, Fredric. Pós-modernismo ou a lógica cultural do capitalismo tardio. São Paulo: Ática, 2007, p. 45.

${ }^{110}$ DEBORD, Guy. Sociedade do espetáculo. Rio de Janeiro: Contraponto, 1997.

${ }^{111}$ HARVEY, David. Condição pós-moderna. São Paulo: Edições Loyola, 2002, p. 49.
} 
A destruição do passado - ou melhor, dos mecanismos sociais que vinculam nossa experiência pessoal à das gerações passadas - é um dos fenômenos mais característicos e lúgubres do final do século XX. Quase todos os jovens de hoje crescem numa espécie de presente contínuo, sem qualquer relação orgânica com o passado público da época em que vivem. ${ }^{112}$

Se, de fato, conforme Jameson, a lógica da cultura pós-moderna é espacial, o sujeito inserido nessa dinâmica social "perdeu sua capacidade de estender de forma ativa suas pretensões e retenções em um complexo temporal e organizar seu passado e seu futuro como uma experiência coerente (...)". Segue-se que a redução da experiência a "uma série de puros presentes, não relacionados no tempo" ${ }^{113}$ sugere que a concepção da personalidade desse sujeito é como a de um esquizofrênico (não em sentido clínico), impossibilitado de forjar a identidade pessoal (baseada na memória e na unificação temporal) por conta de uma "desordem lingüística"; "sintetizando, Lacan descreve a esquizofrenia como sendo a ruptura na cadeia dos significantes que constituem um enunciado ou um significado". ${ }^{114}$

Na mesma direção, David Harvey aponta que "o colapso dos horizontes temporais e a preocupação com a instantaneidade surgiram em parte em decorrência da ênfase contemporânea no campo da produção cultural em eventos, espetáculos, happenings e imagens da mídia”. ${ }^{115} \mathrm{O}$ efeito disso, reitera o autor, "é o de reenfatizar e até celebrar as qualidades transitórias da vida moderna", que é apenas a metade da arte a que Charles Baudelaire se refere em O pintor da vida moderna. O indivíduo pós-moderno, fluido, experimenta as possibilidades oferecidas pela sofisticada segmentação de mercadorias, e assume diferentes faces no jogo das identidades (qualquer relação com Faces, de Cassavetes, não é mera coincidência), "numa fantasmagoria de condições intercambiáveis e mobilidade aleatória, na qual nenhuma posição na escala social é

\footnotetext{
${ }^{112}$ HOBSBAWM, Eric. Era dos extremos: o breve século XX, 1914-1991. São Paulo: Companhia das Letras, 1995, p. 13.

${ }_{113}$ Idem, Ibidem, p. 52.

114 "O significado [para Lacan] (...) é gerado no movimento de significante ao significado. O que geralmente chamamos de significado - o sentido ou o conteúdo conceitual de uma enunciação - é agora visto como um efeitode-significado, como a miragem objetiva da significação gerada e projetada pela relação interna dos significantes. Quando a relação se rompe, quando se quebram as cadeias da significação, então temos a esquizofrenia sob a forma de um amontoado de significantes distintos e não relacionados." JAMESON, Fredric. Pós-modernismo ou a lógica cultural do capitalismo tardio. São Paulo: Ática, 2007, p. 53.

${ }^{115}$ HARVEY, David. Condição pós-moderna. São Paulo: Edições Loyola, 2002, p. 61.
} 
jamais irrevogavelmente fixa e o estranho só pode ser projetado para fora no replicante ou extraterrestre". ${ }^{116}$

O caráter fundamental dos diferentes campos artísticos pós-modernos é "o apagamento da antiga (característica do alto modernismo) fronteira entre a alta cultura e assim chamada cultura de massa ou comercial" ${ }^{117}$, tendência que, todavia, pode ser encontrada nos primórdios da modernidade, nas Flores do Mal do mesmo Baudelaire. No que tange à esfera comportamental, destaca Hobsbawm:

A novidade da década de 50 foi que os jovens das classes alta e média, pelo menos no mundo anglo-saxônico, que cada vez mais dava a tônica global, começaram a aceitar a música, as roupas e até a linguagem das classes baixas urbanas, ou que o tomavam por tais, como seu modelo. O rock foi o exemplo mais espantoso. ${ }^{118}$

Segundo análise de Jameson, ainda,

The post-modernisms have in fact been fascinated by this whole "degraded" landscape of schlock and kitsch, of TV series and Reader's Digest culture, of advertisement and motels of the late show and the grade-B Hollywood film, of so-called paraliterature with its airport paperback categories of gothic and romance, the popular biography, the murder mystery and science-fiction or fantasy novel: materials they no longer simply "quote", as a Joyce or a Mahler might have done, but incorporate into their very substance. ${ }^{119}$

Nesse contexto, os produtores culturais, aliados às novas tecnologias, reafirmaram e intensificaram esta aproximação entre a "alta" a "baixa" cultura, no entanto, de modo diverso dos vanguardistas (mesmo aqueles que celebravam e acreditavam nas novas tecnologias, como um futurismo):

${ }^{116}$ ANDERSON, Perry. As origens da pós-modernidade. Rio de Janeiro: Jorge Zahar, 1999, p. 129.

${ }_{117}$ JAMESON, Fredric. Pós-modernismo ou a lógica cultural do capitalismo tardio. São Paulo: Ática, 2007, p. 28.

${ }^{118}$ HOBSBAWM, Eric. Era dos extremos: o breve século XX, 1914-1991. São Paulo: Companhia das Letras, 1995, p. 324.

${ }_{119}$ JAMESON, Fredric. Postmodernism, or the Cultural Logic of Late Capitalism. In: The Jameson Reader. Malden: Blackwell publishing, 2005, p. 190. "De fato, os pós-modernismos têm revelado um enorme fascínio justamente por essa paisagem "degradada" do brega e do kitsch, dos seriados de TV e da cultura do Reader's Digest, dos anúncios e dos motéis, dos late shows e dos filmes B hollywoodianos, da assim chamada paraliteratura - com seus bolsilivros de aeroporto e suas subcategorias do romanesco e do gótico, da biografia popular, histórias de mistério e assassinatos, ficção científica e romances de fantasia: todos esses materiais não são mais apenas "citados", como o poderiam fazer um Joyce ou um Mahler, mas são incorporados à sua própria substância." JAMESON, Fredric. Pósmodernismo ou a lógica cultural do capitalismo tardio. São Paulo: Ática, 2007, p. 28. 
Esse rapprochement foi procurado, antes, embora quase sempre de maneira mais revolucionária, quando movimentos como o dadaísmo e o surrealismo inicial, o construtivismo e o expressionismo tentaram levar sua arte ao povo como parte integrante de um projeto modernista de transformação social. ${ }^{120}$

O pós-modernismo, dessa forma, se relaciona de maneira mais próxima com a cultura da vida ordinária, a ponto de integrar-se por completo a ela, e, por meio do aprimoramento da tecnologia de produção/reprodução imagética, “o mundo momentaneamente perde sua profundidade e ameaça se tornar uma película brilhante, uma ilusão estereoscópica, um apanhado de imagens cinematográficas sem nenhuma densidade". ${ }^{121}$

Nesse sentido, é necessário apontar que a análise da indústria cultural de Adorno e Horkheimer, da qual o ensaio jamesoniano é tributário, consiste, sobretudo, na denúncia desse processo de desautonomização da esfera cultural, pela sua inserção no sistema como peça-chave de reprodução da ideologia e manutenção do status-quo. ${ }^{122}$

Em linhas gerais, cabe apontar que a análise de Jameson sobre o papel da tecnologia segue a metodologia materialista, pois a considera como resultado do desenvolvimento do capital, e não como um fenômeno em si mesmo. É válido dizer ainda que nosso autor se apóia nas "rupturas fundamentais do maquinário" (e sua relação com a história do sistema capitalista) propostas por Ernest Mandel em $O$ capitalismo tardio, cuja última grande mudança se deu nos anos 40, com a produção de motores eletrônicos e nucleares (sobre a qual Jameson constrói sua periodização cultural):

Intelectualmente, como indica o próprio título de seu livro, a virada de Jameson para uma teoria do pós-moderno foi possibilitada pelo Capitalismo avançado de Mandel, estudo econômico que situava numa tradição clássica completamente

\footnotetext{
${ }^{120}$ HARVEY, David. Condição pós-moderna. São Paulo: Edições Loyola, 2002, p. 62.

${ }^{121}$ JAMESON, Fredric. Pós-modernismo ou a lógica cultural do capitalismo tardio. São Paulo: Ática, 2007, p. 58.

${ }^{122}$ ADORNO, Theodor, HORKHEIMER, Max. Dialética do Esclarecimento. Rio de Janeiro: Zahar, 1985, p. 16.
} 
distinta do marxismo ocidental. Empiricamente, a própria vida econômica ficou de modo tão penetrada pelos sistemas de informação e persuasão que foi perdendo sentido a noção de uma esfera independente mais ou menos independente de produção cultural. ${ }^{123}$

A descrição de Jameson do que seria essa "nova" tessitura social pós-moderna, suas causas e sintomas, enfoca cada um dos seguintes aspectos:

(...) A new depthless, which finds its prolongation both in contemporary "theory" and in a whole new culture of the image or the simulacrum; a consequent weakening of historicity, both in our relationship to public History and in the new forms of our private temporality, whose "schizophrenic" structure (following Lacan) will determinate new types of syntax or syntagmatic relationships in the more temporal arts; (...) the deep constitutive relationships of all this to a whole new technology, which is itself a figure for a whole new economic world system; and, (...) a brief account of postmodernist mutations in the lived experience of built space itself. ${ }^{124}$

A argumentação é concebida em torno destes elementos acima elucidados, com vistas a provar a hipótese de periodização de uma pós-modernidade tida como continuação e intensificação da modernidade (em vez de ruptura), bem como a tese de que o pós-modernismo é a dominante cultural de uma mutação ocorrida no âmbito da cultura que, todavia, corresponde à uma reestruturação da dinâmica do capital. Nas palavras do autor,

(...) Como se demonstrará mais adiante, decidir se o que se encontra diante de nós é uma ruptura ou uma continuidade se o presente deve ser visto como historicamente original ou como uma mera repetição do mesmo em nova embalagem não é algo que possa ser justificado empiricamente, ou defendido em termos filosóficos, uma vez que essa decisão é, em si mesma, um ato narrativo inaugural que embasa a percepção e a interpretação dos eventos a serem narrados. ${ }^{125}$

${ }^{123}$ ANDERSON, Perry. As origens da pós-modernidade. Rio de Janeiro: Jorge Zahar, 1999, p. 85-86.

124 JAMESON, Fredric. Postmodernism, or The Cultural Logic of Late Capitalism. In: The Jameson Reader. Malden: Blackwell publishing, 2005, p. 193. "Uma nova falta de profundidade, que se vê prolongada tanto na "teoria" contemporânea quanto em toda essa cultura da imagem e do simulacro; um consequente enfraquecimento da historicidade tanto em nossas relações com a história pública quanto em nossas novas formas de temporalidade privada, cuja estrutura "esquizofrênica" (seguindo Lacan) vai determinar novos tipos de sintaxe e de relação sintagmática nas formas mais temporais de arte (...); a profunda relação constitutiva de tudo isso com a nova tecnologia, que é uma das figuras de um novo sistema econômico mundial; e, (...) um breve relato das mutações pósmodernas na experiência vivenciada nos espaço das construções." JAMESON, Fredric. Pós-modernismo ou a lógica cultural do capitalismo tardio. São Paulo: Ática, 2007, p. 32.

${ }^{125}$ Idem, Ibidem, p. 16. 
Ciente das contradições que permeiam toda tentativa de teorização na era do fragmentário e do heterogêneo (que ele brilhantemente compara ao capital, na medida em que "tem que manter uma certa distância interna de si mesma, tem que incluir um corpo estranho num conteúdo alheio (...)" ${ }^{126}$, a periodização é concebida segundo uma hipótese de dominância, pois, "se não chegarmos a uma idéia geral de uma dominante cultural, teremos que voltar à visão da história do presente como pura heterogeinedade, como diferença aleatória, como a coexistência de inúmeras forças distintas cuja efetividade é impossível aferir”. ${ }^{127}$ E aqui valeria acrescentar: “o quão dominante ou disseminada se mostra essa cultura - se tem acolhimento geral ou constitui apenas um campo restrito da vida contemporânea - é objeto de controvérsia", salienta Terry Eagleton. ${ }^{128}$

Assim sendo, a concepção de pós-modernismo esboçada por Jameson é histórica, e não somente estilística ("entender o pós-modernismo não como um estilo, mas como uma dominante cultural: uma concepção que dá margem à presença e à coexistência de uma série de características que, apesar de subordinadas umas as outras, são bem diferentes" ${ }^{129}$ ); ela dá conta de posicioná-lo não apenas como um estilo entre outros que podem ser encontrados na contemporaneidade, mas como o predominante do sistema capitalista em sua terceira fase. A tentativa de encarar o pós-modernismo como histórico afasta de seu ensaio a noção moralizante acerca do fenômeno, e procura localizar a modificação da sua função social:

(...) A questão não é arbitrar, mas enfrentar o pósmodernismo como um componente do estágio atual da história, e investigar suas manifestações culturais - como o vídeo, o cinema, a literatura, a arquitetura, a retórica sobre o mercado - não só como veículos para um novo tipo de hegemonia ideológica, a que é funcional para o novo estágio do capital globalizado, mas também como configurações que permitem ao crítico de cultura destrinchar os germes de "novas formas de coletivo". ${ }^{130}$

Jameson refuta as condenações moralistas do crítico cultural, na medida em que este, “como todos nós, está tão profundamente imerso no espaço pós-moderno, tão profundamente

\footnotetext{
${ }^{126}$ Idem, Ibidem, p. 16.

${ }^{127}$ Idem, Ibidem, p. 31-32.

${ }^{128}$ EAGLETON, Terry. As Ilusões do pós-modernismo. Rio de Janeiro: Zahar, 1998, p. 7.

${ }^{129}$ Idem, Ibidem, p. 29.

${ }^{130}$ CEVASCO, Maria Elisa, COSTA, Iná Camargo. Prefácio a Pós-modernismo ou a lógica cultural do capitalismo tardio. São Paulo: Ática, 2007, p. 7.
} 
tingido e contaminado por suas novas categorias críticas que o luxo da crítica ideológica mais antiga, a indignada renúncia moral do outro, torna-se inviável”. ${ }^{131}$ Em suma: não é possível falar em distância crítica na pós-modernidade. De acordo com Iná Camargo Costa e Maria Elisa Cevasco, ainda, "na sua prática de crítico de cultura, evidencia-se a atualização da vocação histórica do marxismo: estudar o funcionamento do capital desmistificando seu movimento continuado de obscurecimento da consciência”. ${ }^{132}$

Pode-se dizer igualmente que ele procura dar continuidade ao legado de Hegel, na medida em que propõe uma diferenciação entre "o pensar da moralidade individual ou moralização (Moralität) e o domínio totalmente diferente dos valores e práticas coletivas e sociais (Sittilichkeit)" bem como de Marx, que em um famoso trecho do Manifesto "nos incita a fazer o impossível, a saber, pensar esse desenvolvimento [do capitalismo] de forma positiva e negativa ao mesmo tempo". ${ }^{133}$

A recusa de um julgamento moral baseado no gosto acerca do movimento abre a possibilidade, para a crítica, da compreensão, bem como da procura pelo "momento de verdade" da ideologia pós-moderna, ainda que não restem “dúvidas de que a lógica do simulacro, com sua transformação de novas realidades em imagens de televisão, faz muito mais do que meramente replicar a lógica do capitalismo tardio: ela a reforça e a intensifica". "134 Nessas condições históricas, "a crítica da cultura adquire um valor cognitivo (...)”. ${ }^{135}$

Conforme observa Perry Anderson,

A tentação a evitar [por parte de Jameson], acima de tudo, era a do moralismo. A cumplicidade do pós-modernismo com a lógica do mercado e do espetáculo era inequívoca. Mas sua simples condenação era inútil. Repetidamente - para a surpresa de muitos, tanto à esquerda como à direita - Jameson insistiu na futilidade de moralizar sobre a ascensão do pósmoderno. (...) Bem antes de discorrer sobre o pós-moderno, ele definiu a posição com que o veria: a ética, onde quer que reapareça, pode ser tomada como um sinal de tentativa de mistificar e em particular de substituir os juízos complexos e ambivalentes de uma perspectiva mais profundamente política

\footnotetext{
${ }^{131}$ Idem, Ibidem, p. 73.

${ }^{132}$ CEVASCO, Maria Elisa, COSTA, Iná Camargo. Prefácio a Pós-modernismo ou a lógica cultural do capitalismo tardio. São Paulo: Ática, 2007, p. 7.

${ }^{133}$ Idem, Ibidem, p. 73.

${ }^{134}$ Idem, Ibidem, p. 72.

${ }^{135}$ CEVASCO, Maria Elisa, COSTA, Iná Camargo. Prefácio à Pós-modernismo ou a lógica cultural do capitalismo tardio. São Paulo: Ática, 2007, p. 6.
} 
e dialética pelas confortáveis simplificações de um mito binário. ${ }^{136}$

A grande questão, posta tanto por Eagleton em seu ensaio "Jameson and Form" bem como por Perry Anderson em As origens da pós-modernidade, está na exclusão, por parte de Jameson, da esfera política - como uma referência social propriamente dita, uma vez que a escolha do material da pesquisa em si mesma já enuncia a posição política do intérprete (em sentido abrangente) -, compreendida pelo campo maior da ética. O que parece ocorrer em seu método analítico "é uma reserva em relação ao político concebido de modo estrito, isto é, como um domínio independente de ação, prenhe das suas próprias consequências". ${ }^{137}$

Vale destacar que tal decisão não é, certamente, aleatória, uma vez que seu modo de pensamento prioriza a urgência da denúncia ("dentro do sistema, Jameson estava mais preocupado em monitorar que julgar" ${ }^{138}$ ), ainda que fosse possível dizer que há, em seu programa teórico, uma "agenda política", por assim dizer, especialmente no tocante ao mapeamento cognitivo e às políticas culturais. A partir de sua epígrafe em Marxismo e Forma, em que ele cita Mallarmé ("Il n'éxiste d'ouvert à la recherche mentale que deux voies, en tout, où bifurque notre besoin de savoir, l'esthétique d'une part et aussi l'économie politique" ${ }^{139}$ ), Anderson conclui que seu "simbolismo materialista" é de "formidável consistência", e o exemplifica segundo a exclusão de Antonio Gramsci quando dessa apropriação do repertório marxista ocidental. ${ }^{140}$

Por outro lado, a "inclusão" do filósofo alemão Ernest Bloch - e seu princípio esperança - sugere que a veia política em Jameson se dá na procura do impulso utópico, como, por exemplo, em "Reificação e Utopia na Cultura de Massa" (em que ele defende a idéia de que tais impulsos são inerentes mesmo aos produtos da cultura puramente comercial). Todavia, o desejo utópico, situado no plano do conteúdo, é indissociável da forma em que é apresentado; desse

\footnotetext{
${ }^{136}$ ANDERSON, Perry. As origens da pós-modernidade. Rio de Janeiro: Jorge Zahar, 1999, p. 77.

${ }^{137}$ Idem, Ibidem, p. 146.

${ }^{138}$ Idem, Ibidem, p. 149.

139 “Abrem-se à pesquisa mental apenas duas vias ao todo, onde se bifurca a nossa necessidade, a saber, de um lado, a estética e, de outro, a economia política." Idem, Ibidem, p. 143.

140 "Em parte isso se deve sem dúvida à posição marginal da Itália no impressionante usufruto que Jameson faz dos recursos culturais europeus como um todo, com a França, a Alemanha e a Inglaterra como pontos de referência. Mas também ao fato de a obra de Gramsci, criação de um líder comunista preso que reflete sobre a derrota de uma revolução e os caminhos para a possível vitória de outra, não se encaixar na bifurcação do estético e do econômico. Foi uma obra eminentemente política, como teoria do Estado e da sociedade civil. Esse corpo de idéias é deixado de lado na extraordinária retomada do marxismo ocidental por Jameson”. Idem, Ibidem, p. 147.
} 
modo, um "sonho político" adquire formatos diferentes, na medida em que depende da maneira como é expresso. E resta a pergunta: "Podem ser evitados julgamentos entre eles? (...) aqui, colocado da forma mais aguda, está o problema mais geral apresentado pela situação do pósmoderno entre a estética e a economia". ${ }^{141}$

Focalizar no problema da valoração do pós-modernismo significa "levantar a questão mais genuína do destino da cultura em geral, e da função da cultura em particular, como um nível ou instância social na era pós-moderna". ${ }^{142}$ A mudança "significativa de sua função social" implica, segundo a tese de Jameson, a dissolução da "semi-autonomia" da esfera cultural. Entretanto, não significa que ela tenha desaparecido ou sido extinta; pode-se dizer que, em parte, o projeto vanguardista se concretizou, e houve, por assim dizer, a reestetização da vida, ou a superação da autonomia da arte, de sua distância com a práxis vital: "O que devemos perguntar agora é se precisamente essa semi-autonomia da esfera cultural não foi destruída pela lógica do capitalismo tardio?" ${ }^{43}$ Nas palavras de Iná Camargo e Maria Elisa Cevasco, "nessa nova versão expandida e atualizada do velho mundo do capital, não mais se trata de ver a cultura como expressão relativamente autônoma da organização social mas sim de entender que nesse novo estágio do capital a lógica do sistema é cultural (...)”. ${ }^{144}$

Nessa mesma linha de raciocínio, esclarece Perry Anderson: "empiricamente, a vida econômica em si mesma tinha se tornado, de qualquer maneira, tão permeada pelos sistemas simbólicos de informação e persuasão que a noção de uma esfera independente de produção mais ou menos a-cultural progressivamente perdeu o significado". ${ }^{145}$

Tal dissolução da autonomia deve ser pensada, conforme Jameson,

(...) Em termos de uma explosão: uma prodigiosa expansão da cultura por todo o domínio social até o ponto em que tudo em nossa vida social - do valor econômico e do poder do Estado, às práticas e a própria estrutura da psique - pode ser considerado como cultural, em um sentido que não foi, até

\footnotetext{
${ }^{141}$ ANDERSON, Perry. As origens da pós-modernidade. Rio de Janeiro: Jorge Zahar, 1999, p. 151.

${ }^{142}$ Idem, Ibidem, p. 74.

${ }^{143}$ Idem, Ibidem, p. 74.

${ }^{144}$ CEVASCO, Maria Elisa, COSTA, Iná Camargo. Prefácio à Pós-modernismo ou a lógica cultural do capitalismo tardio. São Paulo: Ática, 2007, p. 6.

${ }^{145}$ (tradução nossa) "Empirically, economic life itself had anyway become so pervaded by the simbolic systems of information and persuasion the the notion of an independent sphere of more or less a-cultural production increasingly lost meaning". ANDERSON, Perry. The origins of Post-modernity. New York: Verso, 2006, p. 73.
} 
agora, teorizado. (...) Dizer que os dois termos, cultural e econômico, se fundem desse modo um no outro e significam a mesma coisa, eclipsando a distinção entre base e superestrutura, o que em si mesmo pareceu a muitos ser uma característica significativa do pós-moderno, é o mesmo que sugerir que a base, no terceiro estágio do capitalismo, gera sua superestrutura através de um novo tipo de dinâmica. ${ }^{146}$

Nosso autor assinala a insuficiência da terminologia da cooptação para uma situação em que "não apenas as formas contraculturais (...), mas também as intervenções explicitamente políticas são, de algum modo, secretamente desarmadas e reabsorvidas pelo sistema do qual podem ser consideradas parte integrante, uma vez que não conseguem se distanciar dele" ${ }^{147}$, ao se valerem da mesma lógica da circulação típica da forma-mercadoria.

O "novo e original espaço global, extremamente desmoralizante e deprimente" seria o "momento de verdade" do pós-modernismo, na medida em que "não é meramente uma ideologia cultural ou uma fantasia, mas é uma realidade genuinamente histórica (e sócio-econômica) (...)". ${ }^{148}$ Todavia, cabe perguntar se tal realidade não está restrita às cidades e metrópoles dos países desenvolvidos ou em vias de desenvolvimento. A questão, no limite, pode ser formulada nos seguintes termos: Quem faz parte desse espaço multinacional?

Nesse sentido, discutir a tese concebida por Fredric Jameson constitui a principal vertente dessa pesquisa. A expansão da cultura parece ser um fenômeno indiscutível da experiência pósmoderna, contudo, a sua completa fusão com o campo econômico a ponto de tornar-se sua lógica intrínseca (de modo a não podermos mais descrevê-las separadamente, como afirma Jameson) talvez possa ser objeto de controvérsia e discussão, sob um enfoque materialista das condições de produção do capitalismo tardio, o que equivale a dizer, em termos de política econômica. Parafraseando Marx, “a Economia Política não é tecnologia. [É] a relação das determinações gerais da produção, em um grau social dado, com as formas particulares de produção (...)". ${ }^{149}$ É possível afirmar, segundo esse raciocínio, que o pós-modernismo seja a ideologia que azeita o funcionamento do capitalismo tardio.

\footnotetext{
${ }^{146}$ JAMESON, Fredric. Pós-modernismo ou a lógica cultural do capitalismo tardio. São Paulo: Ática, 2007, p. 25, 74.

147 Idem, Ibidem, p. 75.

${ }^{148}$ Idem, Ibidem, p. 75.

${ }^{149}$ MARX, Karl. Contribuição à crítica da Economia Política. São Paulo: Expressão Popular: 2008, p. 241.
} 
No que concerne ao seu alcance, ainda, por fim, encerra Jameson:

I am very far from feeling that that all cultural production today is "postmodern" in the broad sense I will be confering on this term. The postmodern is however the force field in which very different kinds of cultural impulses - what Raymond Williams has usefully termed "residual" and "emergent" forms of cultural production - must take their way. ${ }^{15}$

150 JAMESON, Fredric. Postmodernism, or The Cultural Logic of Late Capitalism. In: The Jameson Reader. Malden: Blackwell publishing, 2005, p. 193. "Não me parece, de modo algum, que toda produção cultural de nossos dias é pós-moderna no sentido amplo em que vou usar esse termo. O pós-moderno é, no entanto, o campo de forças em que vários tipos bem diferentes de impulso cultural - o que Raymond Williams chamou, certeiramente, de formas 'residuais' e 'emergentes' de produção cultural - têm que encontrar seu caminho." JAMESON, Fredric. Pósmodernismo ou a lógica cultural do capitalismo tardio. São Paulo: Ática, 2007, p. 31. 
O capital é a potência da sociedade burguesa, que domina tudo (...)

(Karl Marx, Contribuição à Crítica da Economia Política.)

A elevação do padrão de vida das classes inferiores, materialmente considerável e socialmente lastimável, reflete-se na difusão hipócrita do espírito.

(Theodor Adorno, Max Horkheimer, Dialética do Esclarecimento.)

\section{Breve histórico de uma fase capitalista: do Fordismo à Acumulação Flexível}

\subsection{Projeto Moderno, Modernismo e Pós-Modernismo}

É necessário apontar que a sociedade que emerge do pós-guerra se consolida, em grande medida, apenas na década de 70, como atestam as palavras de David Harvey: “(...) terá a vida social se modificado tanto a partir do início dos anos 70 que possamos falar sem errar que vivemos numa cultura pós-moderna, numa época pós-moderna?" 151

Em Condição pós-moderna, Harvey analisa o pós-modernismo essencialmente em sua comparação com o modernismo e o projeto da modernidade como um todo. Esse por sua vez, filho legítimo do Iluminismo, procurava "desenvolver a ciência objetiva, a moralidade e a lei universais e a arte autônoma nos termos da própria lógica interna destas". ${ }^{152}$ Entretanto,

\footnotetext{
(...) Na medida em que ele também saudava a criatividade humana, a descoberta científica e a busca da excelência individual em nome do progresso humano, os pensadores iluministas acolheram o turbilhão da mudança e viram a transitoriedade, o fugidio e o fragmentário como condição necessária por meio da qual o projeto modernizador poderia ser realizado. ${ }^{153}$
}

\footnotetext{
${ }^{151}$ HARVEY, David. Condição pós-moderna. São Paulo: Edições Loyola, 2002, p. 18.

${ }^{152}$ Idem, Ibidem, p. 23.

${ }^{153}$ Idem, Ibidem, p. 23.
} 
Desse modo, e principalmente amparados na idéia de progresso linear e "desenvolvimento", a relação que muitos modernos estabeleceram com o passado foi a de negação, e a agenda desse projeto era pautada nos termos de uma ruptura com a tradição em nome da construção desse admirável mundo novo: “o pensamento iluminista (...) abraçou a idéia do progresso e buscou ativamente a ruptura com a história e a tradição esposada pela modernidade". ${ }^{154}$ A era moderna era composta, por assim dizer, de um corpo juvenil em transformação, ansiando aproveitar das imensas possibilidades da experiência da emancipação e da liberdade, mas dotado de uma mentalidade dura, permeada por idéias e ideais a serviço da razão totalizadora e totalizante.

O conjunto das imagens iluministas sobre os direitos universais e a razão entraram em crise com as experiências da guerra e do genocídio, isso sem mencionar, ainda no século XIX, as manifestações populares como a dos insurrectos de 1848 na Europa bem como a Comuna de Paris em 1871; “o século XX - com seus campos de concentração e esquadrões da morte, seu militarismo e duas guerras mundiais, sua ameaça de aniquilação nuclear e sua experiência de Hiroshima e Nagasaki" 155 acabaram por demonstrar o "lado sombrio" dessa razão instrumental. $^{156}$

Para além do colapso da civilização, saber se o projeto da modernidade esteve sempre fadado a levar à Auschwitz é uma questão crucial no debate, uma vez que o cerne do pensamento filosófico pós-modernista é, em nome da emancipação humana, abandonar por inteiro o projeto do Iluminismo. Não obstante, o século que viu e glorificou na razão e na ciência a suprema faculdade do homem não pode estar para nós inteiramente superado ${ }^{157}$, a despeito do esforço de um Lyotard em demonstrar a perda da legitimidade do discurso filosófico calcado no ideal de emancipação, e que tem na verdade e na justiça os cernes de sua busca. ${ }^{158}$

\footnotetext{
${ }^{154}$ Idem, Ibidem, p. 23.

${ }^{155}$ Idem, Ibidem, p. 23.

${ }^{156}$ Vale desctacar as célebres palavras de Adorno e Horkheimer em Dialética do esclarecimento: "No sentido mais amplo do progresso do pensamento, o esclarecimento tem perseguido sempre o objetivo de livrar os homens do medo e de investí-los na posição de senhores. Mas a terra totalmente esclarecida resplandece sob o signo de uma calamidade triunfal". ADORNO, Theodor W., HORKHEIMER, Max. Dialética do esclarecimento: fragmentos filosóficos. Rio de Janeiro: Jorge Zahar Ed., 1985, p.19.

${ }^{157}$ CASSIRER, Ernst. A Filosofia do Iluminismo. Campinas: Editora da Unicamp, 1997.

158 "Dans la société ET la culture contemporaine, société post-industrielle, culture postmoderne, la question de la légitimation du savoir se pose em d'autres termes. Le grand récit a perdu as crédibilité, quel que soit le mode d'unification qui lui est assigné: récit spéculatif, récit de l' emancipation. (...) Le principe d'un métalangage universel est remplacé par celui de la pluralité de systèmes formels ET axiomatiques capables d'argumenter dès
} 
Todavia, "se o reino da liberdade só começa quando o reino da necessidade é superado (Aristóteles)", então o lado progressista da história burguesa (em particular a criação de enormes forças produtivas) tinha de ser plenamente reconhecido, e os resultados positivos da racionalidade iluminista, plenamente apropriados". ${ }^{159}$

Por conseguinte, na esfera do pensamento ${ }^{160}$, a pós-modernidade condena as metanarrativas interpretativas, como as de um Marx ou um Freud, na medida em que as considera como "totalizantes", e as metalinguagens, uma vez que dá voz à pluralidade de discursos, baseado nas considerações sobre conhecimento e poder do francês Michael Foucault e dos “jogos de linguagem” de Lyotard ${ }^{161}$ : "seu nervosismo em relação a conceitos como verdade alarmou os bispos e encantou os executivos". ${ }^{162}$

Nessa mesma direção, aponta Eagleton:

O descrédito teórico da idéia de totalidade não surpreende numa época de derrota política para a esquerda. (...) De onde mais que o pós-modernismo possa brotar - da sociedade "pósindustrial", do último fator de descrédito da modernidade, da recrudescência da vanguarda, da transformação da cultura em mercadoria, da emergência de novas forças políticas vitais, do colapso de certas ideologias clássicas da sociedade e do sujeito - ele não deixa de ser, acima de tudo, o resultado de um fracasso político que ele ou jogou no esquecimento ou com o qual ficou o tempo todo brigando em pensamento. ${ }^{163}$

\footnotetext{
énoncés dénotatifs, ces systèmes étant décrits dans une metalangue universelle mais non consistante." LYOTARD, Jean-François. La condition post-moderne. Lonrai: Les Editions de Minuit, 2010, p. 63/72. "Na sociedade e na cultura contemporânea, sociedade pós-industrial, cultura pós-moderna, a questão da legitimação do saber coloca-se em outros termos. O grande relato perdeu sua credibilidade, seja qual for o modo de unificação que lhe é conferido: relato especulativo, relato da emancipação. (...) O princípio de uma metalinguagem universal é substituído pelo da pluralidade de sistemas formais e axiomáticos capazes de argumentar enunciados denotativos, sendo estes sistemas descritos numa metalíngua universal mas não consistente" (tradução nossa).

${ }^{159}$ HARVEY, David. Condição pós-moderna. São Paulo: Edições Loyola, 2002, p. 24, 25.

${ }^{160}$ De acordo com Harvey, "na filosofia, uma onda de pragmatismo americano revivido com a onda pós-marxista e pós-estruturalista que abalou Paris depois de 1968 produziu o que Bernstein $(1985,25)$ chama de "raiva do humanismo e do legado do iluminismo'. Isso desembocou numa vigorosa denúncia da razão abstrata e numa profunda aversão a todo projeto que buscasse a emancipação humana universal pela mobilização das forças da tecnologia, da ciência e da razão." HARVEY, David. Condição pós-moderna. São Paulo: Edições Loyola, 2002, p. 46-47.

${ }^{161}$ La question n'est pás de connaître ce qu' est l'adversaire (la nature), elle est de savoir à quel jeu elle joue.” LYOTARD, Jean-François. La condition post-moderne. Lonrai: Les Editions de Minuit, 2010, p. 93.

${ }^{162}$ EAGLETON, Terry. As Ilusões do pós-modernismo. Rio de Janeiro: Zahar, 1998, p. 36.

${ }^{163}$ Idem, Ibidem, p. 30.
} 
Parte da força do pós-modernismo, no entanto, advém de seus "tópicos políticos privilegiados", do fato de ter introduzido na agenda política questões de sexualidade, gênero e etnicidade; substitutos "para as formas mais clássicas de política radical, que trabalhava com classe, estado, ideologia, revolução [e] modos materiais de produção". ${ }^{164}$

Cabe apontar ainda para o resgate das noções desconstrutivas de Nietzsche, "que enfatiza o profundo caos da vida moderna e a impossibilidade de lidar com ele com o pensamento racional", e igualmente seu posicionamento acerca da estética acima da ciência, da racionalidade e da política, em suma, "acima do bem e do mal". ${ }^{165}$ Ainda que tais tendências possam ser encontradas já no modernismo, é na cultura do pós-moderno que deixam de ser um "sintoma", para transformar-se na "própria doença". ${ }^{166}$

Segue-se que o pós-modernismo pode ser considerado como resultado da emergência da particularidade estético-modernista americana (liberal, plural, contra o totalitarismo) elevada à categoria de universal, "transformando a rebelião artística em agressiva ideologia liberal": ${ }^{167}$ nesse sentido, o pós-modernismo é a superestrutura - ou ideologia - do neoliberalismo. No entanto, para Jameson, “infelizmente”, toda e qualquer descrição infra-estrutural do pós-moderno já é uma descrição cultural, dada a fusão das duas esferas defendida por ele. Pode-se dizer que há certo exagero na sua posição uma vez que é possível - e essa é a tentativa aqui empreendida abordar objetivamente as tranformações econômicas operadas na base material, no que concerne à produção e circulação de mercadoria e capital. É esta eventual lacuna que este estudo procura, na medida do possível, preencher: compreender a história político-econômica da origem da neoliberalização e o modo como proliferou em diferentes regiões no cenário mundial.

\footnotetext{
${ }^{164}$ Idem, Ibidem, p. 31.

${ }^{165}$ Idem, Ibidem, p. 49.

${ }^{166}$ JAMESON, Fredric. Pós-modernismo ou a lógica cultural do capitalismo tardio. São Paulo: Ática, 2007, p. 16.

${ }^{167}$ Vale destacar, igualmente, que o projeto iluminista da modernidade tinha duas vertentes. Uma era a diferenciação pela primeira vez entre ciência, moralidade e arte, não mais fundidas numa religião revelada mas como esferas de valor autônomas, cada uma governada por suas próprias normas: verdade, justiça, beleza. A outra era a soltura desses domínios recém-liberados no fluxo subjetivo da vida cotidiana, interagindo para enriquecê-la. Foi este programa que perdeu o rumo. Porque, em vez de penetrar nos recursos comuns da comunicação diária, cada esfera tendeu a desenvolver-se em uma especialidade esotérica, fechada ao mundo dos significados ordinários. No século XIX a arte tornou-se um enclave crítico cada vez mais alienado da sociedade, fetichizando mesmo a distância em relação à ela. No começo do século XX, vanguardas revolucionárias como o surrealismo tentaram demolir a divisão resultante entre a arte e a vida através de atos espetaculares de vontade estética. Mas seus gestos foram fúteis: nenhuma emancipação resultou da destruição das formas ou da dessublimação dos significados nem a vida poderia ter sido jamais transfigurada pela absorção exclusiva da arte. Isso requeria também uma recuperação e a interação das três para animar o mundo da vida. HARVEY, David. Condição pós-moderna. São Paulo: Edições Loyola, 2002, p. $34,44-45$.
} 


\subsection{A Transição}

A transformação do regime de acumulação e do modo de regulamentação ${ }^{168}$ do sistema capitalista em sua última fase - o atual neoliberalismo - implicou mudanças na economia política que por certo levaram ao estabelecimento de uma nova configuração mundial; todavia, cabe ressaltar: "no Ocidente ainda vivemos uma sociedade em que a produção em função de lucros permanece como o princípio organizador básico da vida econômica”. 169

De acordo com Harvey, existem duas grandes áreas num sistema como o da acumulação de capital que devem ser negociadas a fim de mantê-lo viável. A primeira, descreve ele, "advém das qualidades anárquicas dos mercados de fixação de preços, e a segunda deriva da necessidade de exercer suficiente controle sobre o emprego da força de trabalho para garantir a adição de valor na produção e, portanto, lucros positivos para o maior numero de capitalistas". ${ }^{170}$

O marco da ruptura, para fins de periodização, se dá com a crise do petróleo em 1973, quando o conjunto de regras básicas que geria a produção de mercadorias começa a se modificar. O colapso do sistema deu início a um período em que novas práticas político-econômicas entraram em jogo com o propósito de moldar a trajetória e a forma de desenvolvimento capitalista. Em outros termos, a tríade responsável pelo crescimento econômico dos anos dourados - fordismo, keynesianismo e intervenção estatal - não dava mais conta de manter o consumo e a taxa de lucro de outrora:

(...) O longo período de expansão do pós-guerra, que se estendeu de 1945 a 1973, teve como base um conjunto de práticas de controle de trabalho, tecnologias, hábitos de consumo e configurações de poder político-econômico (...) que pode ser chamado de fordista-keynesianista.

\footnotetext{
${ }^{168}$ Um regime de acumulação, conforme o autor, "descreve a estabilização, por um longo período, da alocação do produto líquido entre consumo e acumulação; ele implica alguma correspondência entre a transformação tanto das condições de produção como das condições de reprodução de assalariados." O modo de regulamentação, por sua vez, implica "uma materialização do regime de acumulação, que toma a forma de norma, hábitos, leis, redes de regulamentação etc. que garantem a unidade do processo, isto é, a consistência apropriada entre comportamentos individuais e o esquema de reprodução.” HARVEY, David. Condição pós-moderna. São Paulo: Edições Loyola, 2002, p. 117.

${ }^{169}$ Idem, Ibidem, p. 117.

${ }^{170}$ Idem, Ibidem, p. 119.
} 
Durante os anos 50 os benefícios materiais puderam ser sentidos - a qualidade de vida de uma considerável parcela da humanidade havia de fato melhorado se comparada em especial ao entre guerras; contudo, foi depois que o sistema apresentou os primeiros sinais de cansaço, nos “perturbados anos 70, à espera dos traumáticos anos 80 , os observadores - sobretudo, para início de conversa, os economistas - começaram a perceber que (...) o mundo do capitalismo desenvolvido, passara por uma fase excepcional de sua história (...)”. ${ }^{171}$

Vale salientar, em conformidade com o historiador Eric Hobsbawm, que os efeitos dessa expansão alcançaram essencialmente os países capitalistas desenvolvidos - posto terem representado cerca de três quartos da produção do mundo, e mais de $80 \%$ das exportações manufaturadas. ${ }^{172}$ Ainda assim, "a Era de Ouro foi um fenômeno mundial, embora a riqueza geral jamais chegasse à vista da maioria da população do mundo - os que viviam em países para cuja pobreza e atraso os especialistas da ONU tentavam encontrar eufemismos diplomáticos”. ${ }^{173}$

Não obstante, "o mundo industrial, claro, se expandia por toda parte; nas regiões capitalistas e socialistas e no 'Terceiro Mundo", e junto com ele a urbanização: "os centros das cidades, grandes e pequenos, foram postos abaixo e 'incorporados' por todo o mundo, incidentalmente destruindo catedrais medievais", e, por exetnsão, a memória coletiva. ${ }^{174}$

Com efeito, um dos motivos pelos quais a Era de Ouro se sustentou foi o preço do barril de petróleo (provindo da Arábia Saudita) que, durante o período de 1950-73, custara em média menos de dois dólares, de modo que a energia barata empregada nos processos produtivos sustentava a taxa de lucro. Só depois de 1973, quando o cartel de produtores de petróleo decidiu “cobrar o que o mercado podia pagar", é que a disputa pelo mineral se acirrou.

O "surto econômico", assinala ainda Hobsbawm, foi movido pela revolução tecnológica - baseada na constante inovação dos meios de produção e nos maciços investimentos em pesquisa científica (que agora encontrava rápida aplicação prática para seus resultados): “a

\footnotetext{
${ }^{171}$ HOBSBAWM, Eric. Era dos extremos: o breve século XX, 1914-1991. São Paulo: Companhia das Letras, 1995, p. 253.

${ }_{172}^{172}$ Idem, Ibidem, p. 255.

${ }^{173}$ Idem, Ibidem, p. 255.

174 "Como as autoridades no Oriente e no Ocidente também descobriram que se podia usar métodos industriais para construir rapidamente conjuntos habitacionais baratos, enchendo os arredores das cidades de prédios de apartamentos visivelmente ameaçadores, a década de 1960 provavelmente ficará como a mais desastrosa na história da urbanização humana." HOBSBAWM, Eric. Era dos extremos: o breve século XX, 1914-1991. São Paulo: Companhia das Letras, 1995, p. 257.
} 
indústria e mesmo a agricultura pela primeira vez ultrapassavam decididamente a tecnologia do século XIX". ${ }^{175}$ A lista de produtos que visivelmente transformaram o contexto é interminável, mas cabe destacar os mais importantes: televisão, eletrodomésticos e equipamentos de foto $\mathrm{e}$ vídeo. Nesse sentido, a tecnologia modificou drasticamente a vida cotidiana até mesmo em regiões distantes dos países não desenvolvidos, onde o rádio portátil (devido ao transistor e à bateria em miniatura de longa duração) pôde chegar.

Pode-se dizer, igualmente, que a revolução tecnológica entrou "na consciência do consumidor" de tal maneira que a categoria de inovação passou a pautar a valoração dos produtos, e se tornou o principal recurso para a circulação da forma-mercadoria; "a crença era que o 'novo' equivalia não só a melhor, mas a absolutamente revolucionado". ${ }^{176}$

Na Era de Ouro, finalmente, conclui Hobsbawm,

(...) Todos os problemas que perseguiam o capitalismo em sua era da catástrofe pareceram dissolver-se e desaparecer. O terrível e inevitável ciclo de prosperidade e depressão, tão fatal entre as guerras, tornou-se uma sucessão de brandas flutuações, graças a - era o que pensavam os economistas keynesianos que agora assessoravam os governos - sua inteligente administração macroeconômica. (...) Como vamos explicar esse extraordinário e inteiramente inesperado triunfo de um sistema que, durante metade de uma vida, parecera à beira da ruína? (...) $\mathrm{O}$ que exige explicação (...) [é] a escala e a profundidade extraordinárias desse boom secular, que é uma espécie de contrapartida da escala e profundidade extraordinária da era anterior de crises e depressões. ${ }^{177}$

\subsection{O Fordismo, o Keynesianismo, a Intervenção Estatal}

A data inicial simbólica do fordismo é 1914, quando o americano Henry Ford introduziu seu dia de "oito horas e cinco dólares" para seus trabalhadores na linha de montagem de carros, em Dearbon, Michigan. No entanto, o modo de implantação do fordismo em si foi mais complexo, e incluiu, sobretudo, uma série inovações tecnológicas e organizacionais que

\footnotetext{
${ }^{175}$ Idem, Ibidem, p. 260.

${ }^{176}$ Idem, Ibidem, p. 261.

${ }^{177}$ HOBSBAWM, Eric. Era dos extremos: o breve século XX, 1914-1991. São Paulo: Companhia das Letras, 1995, p. 262, 263.
} 
resultaram num "aprimoramento" do sistema de produção de mercadorias. Sobre o assunto, vale transpor um comentário de Harvey:

\begin{abstract}
A forma corporativa de organização dos negócios (...) já tinha sido aperfeiçoada pelas estradas de ferro ao longo do século XIX e já tinha chegado, em particular depois da onda de fusões e de formação de trustes e cartéis no fim do século, a muitos setores industriais. (...) Ford também fez pouco mais do que racionalizar velhas tecnologias e uma detalhada divisão do trabalho preexistente, embora, ao fazer o trabalho chegar ao trabalhador numa posição fixa, ele tenha conseguido dramáticos ganhos de produtividade. (...) o que havia de especial em Ford (e que, em última análise, distingue o fordismo do taylorismo) era a sua visão, seu reconhecimento explícito de que a produção de massa significava consumo de massa, um novo sistema de reprodução da força de trabalho, uma nova política de controle e gerência do trabalho, uma nova psicologia, em suma, um novo tipo de sociedade democrática, racionalizada, modernista e populista. ${ }^{178}$
\end{abstract}

Os novos métodos de trabalho implicaram o surgimento de um novo tipo de trabalhador e, por sua vez, de um modo específico de sociabilidade. Nesse processo, as questões de sexualidade, a família, as formas de coerção moral, de consumismo e de ação do Estado atuavam em conjunto na tentativa de forjar esse moderno trabalhador, adequado ao processo produtivo. Sob esse paradigma, pode-se dizer que na base da crença de Ford estava a idéia de que um novo tipo de sociedade poderia ser construído com a "aplicação adequada ao poder corporativo". A disciplina tanto pessoal (em relação ao trabalho dos indivíduos nas fábricas) quanto coletiva (uma "certa probidade moral", a valorização da vida familiar e o consumo prudente) foi essencial para o estabelecimento do sistema fordista.

Contudo, a força do poder corporativo de regulamentação da economia não deu conta de superar a força das leis coercitivas da competição e a conseqüente Grande Depressão que se seguiu nos anos 30: "foi necessário o New Deal de Roosevelt para salvar o capitalismo - fazendo através da intervenção do Estado, o que Ford tentara fazer sozinho". ${ }^{179}$

A maneira como o fordismo foi estabelecido pode ser contada por meio de uma série de histórias que se estendem por mais de meio século, e que derivaram ora de decisões individuais,

\footnotetext{
${ }^{178}$ HARVEY, David. Condição pós-moderna. São Paulo: Edições Loyola, 2002, p. 121.

${ }^{179}$ Idem, Ibidem, p. 122.
} 
ora corporativas - institucionais e estatais, sendo a maioria escolhas políticas feitas, segundo Harvey, ao acaso, ou respostas a crises estruturais do sistema capitalista. A Segunda Guerra foi, igualmente, "responsável" por endossar a lógica do planejamento em larga escala e da racionalização do processo de trabalho: "era difícil para capitalistas e trabalhadores recusar racionalizações que melhorassem a eficiência numa época de total esforço. (...) A direita e a esquerda desenvolveram sua própria versão de planejamento estatal racionalizado (...)”. ${ }^{180}$

Na visão de Harvey, houve, no período entreguerras, dois fatores que impediram a disseminação do sistema fordista. O primeiro deles residia no impasse gerado pelas relações de classe no mundo, por assim dizer. Na medida em que o capitalismo impunha um modo de produção calcado na "familiarização do trabalhador", com suas longas horas de trabalho controladas e altamente rotinizadas -, e na falta de conhecimento da totalidade do processo produtivo, é possível afirmar que talvez não tenha sido propício à aceitação; “foi preciso uma enorme revolução das relações de classe (uma revolução que começou nos anos 30, mas só deu frutos nos anos 50) para acomodar a disseminação do fordismo à Europa". ${ }^{181}$

O segundo empecilho eram os mecanismos de intervenção estatal. Foi necessário estabelecer um novo modo de regulamentação que atendesse às demandas dos preceitos de Ford, após o quase colapso econômico do sistema na década de 30 - em que a crise se manifestou fundamentalmente como falta de demanda efetiva por produtos. A saída do impasse para o fracasso evidente dos governos democráticos em "acomodar a crônica incapacidade do capitalismo de regulamentar as condições essenciais de sua própria produção" ${ }^{182}$ foi, para países como Alemanha, Itália e Japão, o estabelecimento de governos totalitários baseados no nacionalsocialismo. O problema - tal como o via um economista como Keynes - era alcançar uma maneira de estabilizar o capitalismo por meio de um conjunto de estratégias administrativas científicas e poderes estatais, mas que evitasse, ao mesmo tempo, "as evidentes repressões e irracionalidades, toda a beligerância e todo o nacionalismo estreito que as soluções nacionalsocialistas implicavam" ${ }^{183}$, e que desembocaram, por sua vez, na Segunda Guerra Mundial.

\footnotetext{
${ }^{180}$ Idem, Ibidem, p. 123.

${ }^{181}$ Idem, Ibidem, p. 124.

${ }^{182}$ Idem, Ibidem, p. 124.

${ }^{183}$ Idem, Ibidem, p. 124.
} 
A questão do uso e da configuração dos poderes do Estado só veio a ser "resolvida" no pós-guerra - quando o fordismo se aliou ao keynesianismo, e o sistema promoveu expansões de alcance mundial, atraindo notadamente nações descolonizadas. Uma série de indústrias baseadas em tecnologias que haviam sido amadurecidas no entreguerras e aperfeiçoadas no pós-guerra ascenderam e se tornaram propulsoras do crescimento econômico: carros, navios, equipamentos de transporte, aço, produtos petroquímicos, borracha e eletrodomésticos, para citar os principais. O outro vértice do crescimento apoiava-se na reconstrução das economias devastadas pela guerra - patrocinada pelos Estados-nação -, na renovação urbana, na expansão geográfica dos sistemas de transporte e comunicação e no desenvolvimento infra-estrutural, nos países desenvolvidos e não desenvolvidos, em escalas diferentes. ${ }^{184}$

Para além das inovações tecnológicas, a explosão econômica dos anos dourados foi possibilitada, sobretudo, por uma série de compromissos assumidos bem como de novos posicionamentos dos atores sociais envolvidos no processo; em outras palavras, numa nova relação entre trabalho, capital e Estado. Contudo, assinala Harvey, "o equilíbrio do poder, tenso mas mesmo assim firme, que prevalecia entre o trabalho organizado, o grande capital corporativo e a nação-Estado (...) não foi alcançado por acaso - resultou de anos de luta". ${ }^{185}$ Vale destacar

\footnotetext{
${ }^{184}$ Idem, Ibidem, p. 125.

${ }^{185}$ Para uma compreensão maior da função de cada um, os esclarecimentos de Harvey são certeiros: "Utilizava-se o grande poder corporativo para assegurar o crescimento sustentado de investimentos que aumentassem a produtividade, garantissem o crescimento e elevassem o padrão de vida enquanto mantinham uma base estável para a realização de lucros. Isso implicava um compromisso corporativo com processos estáveis, mas vigorosos de mudança tecnológica, com um grande investimento de capital fixo, melhoria da capacidade administrativa na produção e no marketing e mobilização de economias de escala mediante a padronização do produto. A forte centralização do capital, que vinha sendo uma característica tão significativa do capitalismo norte-americano desde 1900, permitiu refrear a competição intercapitalista numa economia americana toda poderosa e fazer surgir práticas de planejamento e de preços monopolistas e oligopolistas. A administração científica de todas as facetas da atividade corporativa (não somente produção como também relações pessoais, treinamento no local de trabalho, marketing, criação de produtos, estratégia de preços, obsolência planejada de equipamentos e produtos) tornou-se marco da racionalidade corporativa burocrática. As decisões das corporações se tornaram hegemônicas na definição dos caminhos do crescimento do consumo de massa, presumindo-se, com efeito, que os outros dois parceiros da grande coalizão fizessem tudo o que fosse necessário para manter a demanda efetiva em níveis capazes de absorver o crescimento sustentado do produto capitalista. $\mathrm{O}$ acúmulo de trabalhadores nas fábricas de larga escala sempre trazia, no entanto, a ameaça de uma organização trabalhista mais forte e do aumento do poder da classe trabalhadora - daí a importância do ataque político a elementos radicais do movimento operário depois de 1945. Mesmo assim, as corporações aceitaram a contragosto o poder sindical, particularmente quando os sindicatos procuravam controlar seus membros e colaborar com a administração em planos de aumento da produtividade em troca de ganhos de salário que estimulassem a demanda efetiva da maneira originalmente concebida por Ford. O Estado, por sua vez, assumia uma variedade de obrigações. Na medida em que a produção de massa, que envolvia pesados investimentos em capital fixo, requeria condições de demanda relativamente estáveis para ser lucrativo, o Estado se esforçava por controlar ciclos econômicos com uma combinação apropriada de políticas fiscais e monetárias no período pósguerra. Essas políticas eram dirigidas para as áreas de investimento público - em setores como o transporte, os
} 
que o fordismo do pós-guerra não foi meramente um sistema de produção, mas um modo de vida - a produção em massa implicava na padronização do produto e no consumo de massa, e, por sua vez, numa nova estética e "mercantilização da cultura".

O sucesso do fordismo foi devido também à expansão internacional - a abertura do investimento e do comércio estrangeiros (especialmente na Europa) para compensar os limites da demanda efetiva interna americana e o progresso na formação de mercados de massa globais e absorção da população fora do mundo comunista. O desenvolvimento desigual na economia de diferentes países possibilitou a exploração de recursos e matérias primas baratas por parte daqueles que estavam tecnologicamente mais avançados. O internacionalismo implicou ainda uma nova cultura internacional e a aceleração de determinadas atividades, como bancos, seguros, hotéis, aeroportos e o turismo. É válido ressaltar, assinala Harvey, que

(...) Tudo isso se abrigava sob o guarda-chuva hegemônico do poder econômico dos Estados Unidos, baseado no domínio militar. (...) A América agia como banqueiro do mundo em troca de uma abertura dos mercados de capital e de mercadorias ao poder das grandes corporações. Sob essa proteção, o fordismo se disseminou desigualmente, à medida que cada Estado procurava seu próprio modo de administração das relações de classe e, externamente, somente pela sua posição hierárquica na economia mundial e pela taxa de câmbio fixada com base no dólar. Assim, a expansão internacional do fordismo ocorreu numa conjuntura particular de regulamentação politico-econômica mundial e uma configuração geopolítica em que os Estados Unidos dominavam por meio de um sistema bem distinto de alianças militares e relações de poder. ${ }^{186}$

Desnecessário apontar que os benefícios trazidos pelo fordismo não alcançaram aqueles que não tinham acesso ao trabalho nos moldes desse sistema e que, desse modo, não tiravam proveito das "tão louvadas alegrias do consumo de massa". ${ }^{187}$ No que tange à força de trabalho,

equipamentos públicos etc. - vitais para o crescimento da produção e do consumo de massa e que também garantiam um emprego relativamente pleno. Os governos também buscavam fornecer um forte complemento ao salário social com gastos de seguridade social, assistência médica, educação, habitação etc. Além disso, o poder estatal era exercido direta ou indiretamente sobre os acordos salariais e os direitos dos trabalhadores na produção." Idem, Ibidem, p. 125.

${ }^{186}$ Idem, Ibidem, p. 131-132.

${ }^{187}$ Nesse sentido, esclarece ainda Harvey: “(...) a negociação fordista de salários estava confinada a certos setores da economia e a certas nações-Estado em que o crescimento estável da demanda podia ser acompanhado por investimentos de larga escala na tecnologia de produção em massa. Outros setores de produção de alto risco ainda dependiam de baixos salários e de fraca garantia de emprego. E mesmo os setores fordistas podiam recorrer a uma base não fordista de subcontratação". Idem, Ibidem, p. 132. 
segundo nosso autor, ela era predominantemente branca e masculina, e os sindicatos passaram a ser atacados pelas minorias excluídas e pelas mulheres, na medida em que serviam aos interesses apenas de seus membros.

O Estado como mediador entre o trabalho e o capital tinha a responsabilidade de garantir um salário social suficiente, ou engajar-se em políticas públicas de distribuição. Em suma: ações legais que remediassem as desigualdades, combatessem o empobrecimento e a exclusão das minorias. Sua legimitação moral, por assim dizer, dependia da sua capacidade de assegurar os benefícios forditas, assim como oferecer assistência médica, habitação e serviços educacionais. Porém, "a condição de fornecimento de bens coletivos dependia da contínua aceleração da produtividade do traballho no setor corporativo. Só assim o Estado keynesiano do bem-estar social poderia ser fisicamente viável". ${ }^{188}$ Em outros termos, o Estado deveria fazer concessão ao capital.

Finalmente, na ponta do consumo, "havia mais do que uma pequena crítica" a pouca qualidade de vida e de serviços num regime de consumo padronizado sob a égide da racionalidade burocrática técnico-científica, de que os movimentos da década de 60 dão testemunho. ${ }^{189}$ Não obstante, a despeito de todas as críticas, o núcleo essencial do fordismo foi mantido até 1973, quando a recessão abalou esse quadro.

\subsection{A Acumulação Flexível}

A acumulação flexível, como vou chamá-la, é marcada por um confronto direto com a rigidez do fordismo." As dificuldades em manter as contradições do sistema capitalista podiam ser apreendidas, para David Harvey, por meio da rigidez com os investimentos de capital fixo de larga escala e de longo prazo em sistemas de produção em massa, nos mercados e contratos de trabalho. O único instrumento flexível do sistema fordista residia na política monetária - "na capacidade de imprimir moeda em qualquer montante que parecesse necessário para manter a

\footnotetext{
${ }^{188}$ Idem, Ibidem, p. 133.

189 "Devem-se acrescentar a isso todos os insatisfeitos do Terceiro Mundo com um processo de modernização que prometia desenvolvimento, emancipação das necessidades e plena integração ao fordismo, mas que, na prática, promovia a destruição de culturas locais, muita opressão e numerosas formas de domínio capitalista em troca de ganhos bastante pífios em termos de padrão de vida e de serviços públicos (por exemplo, no campo da saúde), a não ser para uma elite nacional muito afluente que decidira colaborar ativamente com o capital.” Idem, Ibidem, p. 133.
} 
economia estável. E assim, começou a onda inflacionária que acabaria por afundar a expansão do pós-guerra". ${ }^{190}$

$\mathrm{Na}$ medida em que a acumulação flexível ainda é uma forma de capitalismo, pode-se afirmar que suas proposições básicas são mantidas. Existem três características essenciais (e aqui Harvey apóia-se em Marx) que configuram tal modo de produção: a orientação para o crescimento, a exploração do trabalho - tanto no processo produtivo quanto no mercado - e a dinamicidade tecnológica e organizacional. ${ }^{191}$ Tais condições, entretanto, são inconsistentes e contraditórias, o que torna o sistema propenso a crises - segundo o argumento marxista, tendências de superacumulação, em que capital e trabalho ociosos (indicados por capacidade produtiva ociosa, excesso de mercadorias e de estoques, um excedente de capital-dinheiro e grande desemprego) não são superados. A reestruturação, dessa forma, opera de modo a conter, absorver e administrar a crise para que a ordem social não seja ameaçada. ${ }^{192}$

Harvey elege e descreve três maneiras pelas quais foi possível a superação da tendência de superacumulação (em diferentes momentos de crise do sistema), introduzindo um conjunto de escolhas político-econômicas que preservaram, por fim, o status quo. A desvalorização - tanto de mercadorias quanto da capacidade produtiva ou do valor do dinheiro - é uma medida que fornece um modo de lidar com excedentes de capital: "há muitos exemplos e abundantes provas da desvalorização como resposta à superacumulação a partir de 1973”. ${ }^{193}$ O controle macroeconômico, por sua vez, contém o problema ao intitucionalizar algum sistema de regulação dos mecanismos de sorte que se possa garantir um crescimento equilibrado. Por fim, a absorção da superacumulação pode se dar por intermédio do deslocamento temporal e espacial, que consistiu na aceleração do tempo de giro e na absorção pela expansão geográfica do capital e do trabalho excedentes, respectivamente.

No pós-guerra, o fordismo resolveu as tendências de superacumulação - além dos deslocamentos temporal e espacial, sob a vigilância do Estado intervencionista - por meio de

\footnotetext{
${ }^{190}$ HARVEY, David. Condição pós-moderna. São Paulo: Edições Loyola, 2002, p. 136, 140.

191 Idem, Ibidem, p. 166-169.

${ }^{192}$ Idem, Ibidem, p. 172.

${ }^{193}$ Nesse sentido, prossegue Harvey: "Mas a desvalorização tem um alto preço político e atinge amplos segmentos da classe capitalista, da classe trabalhadora e das várias outras classes sociais que formam a complexa sociedade capitalista moderna. Uma certa sacudidela pode parecer uma coisa boa, mas as falências descontroladas e a desvalorização maciça expõem o lado irracional da racionalidade capitalista de uma maneira demasiado brutal para serem sustentadas por muito tempo sem produzir algum tipo de resistência revolucionária (de direita ou de esquerda)". Idem, Ibidem, p. 170.
} 
uma estratégia de acumulação fundamentada no controle da desvalorização (mediante obsolescência programada) e na absorção da superacumulação. Por conseguinte, a crise do fordismo pode ser vista notadamente como o esgotamento das opções para solucionar a superacumulação no decorrer da expansão dos anos dourados. ${ }^{194}$

A acumulação flexível, na esfera produtiva, caracteriza-se pela produção em pequenos lotes (sem estoque) e conforme a demanda (just-in-time), pelo controle de qualidade integrado ao processo, por uma aprendizagem na prática e planejamento a longo prazo e, em conseqüência, uma redução do tempo perdido e da "porosidade do trabalho". Cabe destacar ainda que uma boa parcela da produção foi deslocada para o setor de serviços. ${ }^{195}$

No que tange à força de trabalho, é calcada, sobretudo, na subcontratação, no emprego temporário, na multiplicidade das tarefas (e na eliminação, por sua vez, da demarcação de tarefas), em uma horizontalidade na organização do trabalho e numa ênfase na coresponsabilidade do trabalhador: "a produção em pequenos lotes e a subcontratação tiveram por certo a virtude de superar a rigidez do sistema fordista e de atender a uma gama bem mais ampla de necessidades de mercado, incluindo as rapidamente cambiáveis". 196

É preciso atentar para a insistência de que não há nada essencialmente novo na virada do sistema e de que o capitalismo se vale periodicamente desses rearranjos: tal perspectiva "é por certo correta (uma leitura cuidadosa de O Capital de Marx sustenta essa afirmação)". Não

\footnotetext{
194 Segundo Harvey, "o deslocamento temporal estava acumulando dívida sobre dívida [apesar do financiamento estatal como instrumento administrativo para o controle dos ciclos econômicos] até que a única estratégia gorvernamental viável foi afastar o problema através da monetização. Isso foi feito, na verdade, imprimindo-se tanto dinheiro que se disparou um surto inflacionário que reduziu radicalmente o valor real das dívidas passadas (os milhares de dólares emprestados dez anos antes têm pouco valor depois de uma fase de inflação alta). O tempo de giro podia ser acelerado facilmente sem a destruição do valor dos ativos de capital fixo. Foram criados novos centros geográficos de acumulação - o sul e o oeste dos Estados Unidos, a Europa Ocidental e o Japão - e, em seguida, um conjunto de países recém-industrializados. Com a maturação, esses sistemas fordistas de produção se tornaram centros de superacumulação novos e, com frequencia, bastante competitivos. A competição espacial entre sistemas fordistas geograficamente distintos se intensificou, com os regimes mais eficientes (como o japonês) e os de custo de mão-de-obra mais barato (como os países do Terceiro Mundo em que faltavam noções de um contrato social com o trabalho ou em que esses contratos não tinham muita força) levando outros centros a paroxismos de desvalorização através da desindustrialização. A competição espacial entre sistemas aumentou ainda mais, em particular depois de 1973, à medida que se esgotava a capacidade de se resolver o problema da superacumulação por meio do deslocamento geográfico. Assim sendo, a crise do fordismo foi tanto geográfica e geopolítica como uma crise de endividamento, luta de classes ou estagnação corporativa nas nações-Estado. Os mecanismos desenvolvidos para controlar tendências de crise simplesmente terminaram por ser vencidos pela força das contradições subjacentes do capitalismo". HARVEY, David. Condição pós-moderna. São Paulo: Edições Loyola, 2002, p. 173-174.

${ }^{195}$ Idem, Ibidem, p. 167, 181.

196 "A atual tendência dos mercados de trabalho é reduzir o número de trabalhadores "centrais' e empregar cada vez mais uma força de trabalho que entra facilmente e é demitida sem custos quando as coisas ficam ruins." Idem, Ibidem, p.144, 148.
} 
obstante, "as conseqüências ideológicas e políticas da superacentuação da flexibilidade no sentido estrito de técnica de produção e de relações de trabalho são sérias o bastante para nos levar a fazer sóbrias e cautelosas avaliações do grau do imperativo da flexibilidade". ${ }^{197}$

Nesse sentido, Harvey considera igualmente perigoso "fingir que nada mudou", quando é notória a aceleração da desindustrialização nos países de primeiro mundo, e a transferência geográfica em busca de mão-de-obra e matéria-prima baratas, bem como a expansão das práticas flexíveis de trabalho e da automação.

Esse novo tipo de organização do processo produtivo impactou diretamente, desnecessário dizer, a natureza e a composição da classe trabalhadora e, dessa forma, as possibilidades de formação de consciência e ação política - o enfraquecimento dos sindicatos e modos de política institucionais; "a desvalorização do trabalho sempre foi a resposta instintiva dos capitalistas à queda de lucros". A novidade era que o capitalismo flexível havia aumentado as desigualdades de renda, ao fazer emergir "uma nova aristocracia do trabalho (...) e uma subclasse mal-remunerada e totalmente sem poder". ${ }^{198}$

O equilíbrio entre o poder financeiro e o poder do Estado sob o capitalismo é, certamente, delicado, mas o colapso do fordismo-keynesianismo "sem dúvida significou fazer o prato da balança pender para o fortalecimento do capital financeiro." ${ }^{199}$ A partir de 1972 novos sistemas financeiros começaram a ser implantados de modo a transformar o quadro de forças em ação no capitalismo global, o que gerou, por sua vez, uma crescente autonomização do sistema bancário e financeiro em comparação com o financiamento corporativo, estatal e pessoal. ${ }^{200}$ Sob essa perspectiva, acrescenta ainda Harvey:

A acumulação flexível evidentemente procura o capital financeiro como poder coordenador mais do que o fordismo o fazia. Isso significa que a potencialidade de formação de crises financeiras e monetárias autônomas e independentes é muito maior do que antes, apesar de o sistema financeiro ter mais condições de minimizar os riscos através da diversificação e da rápida transferência de fundos de empresas, regiões e setores em decadência para empresas, regiões e setores lucrativos. Boa parte da fluidez, da instabilidade e do frenesi pode ser atribuída diretamente ao aumento dessa capacidade de dirigir os fluxos de capital para lá e para cá de maneiras que quase parecem

\footnotetext{
${ }^{197}$ Idem, Ibidem, p. 179.

${ }^{198}$ HARVEY, David. Condição pós-moderna. São Paulo: Edições Loyola, 2002, p. 181.

${ }^{199}$ Idem, Ibidem, p. 156.

${ }^{200}$ Idem, Ibidem, p. 155.
} 
desprezar as restrições de tempo e de espaço que costumam ter efeito sobre as atividades materiais de produção e consumo. ${ }^{201}$

Com efeito, as mudanças introduzidas foram acompanhadas por um neoconservadorismo na América do Norte e em boa parte da Europa Ocidental. As vitórias de Thatcher e Reagan são o marco da ruptura da política do período pós-guerra, embora, na concepção de Harvey, elas tenham sido mais a consolidação do que já acontecia em boa parte dos anos 70. Para ele, a crise de 1973-75 derivou da rigidez das políticas e práticas do modelo fordista-keynesiano; “as políticas keynesianas tinham se mostrado inflacionárias à medida que as despesas públicas cresciam e a capacidade fiscal se estagnava". ${ }^{202}$

Soma-se a essa conjuntura a gradual retirada de apoio do Estado do bem-estar social, o ataque ao salário real e ao poder sindical - soluções para a crise de 1973-75 e que, todavia, foram transformadas pelos neoconservadores em "virtude governamental". Embora possa ter havido variações (substanciais) de país para país, “os alvos e a capacidade de intervenção estatal sofreram uma grande mudança a partir de 1972 em todo mundo capitalista, pouco importando a tendência ideológica do governo no poder". 203

No horizonte do nosso autor, a novidade do período iniciado em 1972 é o florescimento e transformação dos mercados financeiros. Na fase da acumulação flexível o que emerge são, de fato, sofisticados sistemas de coordernação financeira em escala global, o que permitiu, por sua vez, o fluxo geográfico e temporal do capital e sua acumulação; em suma: a inovação nos sistemas financeiros parece ter sido indispensável para vencer a rigidez fordista e, por extensão, para a superação da crise temporal, geográfica e até política em que o sistema mergulhara da década de 60 .

A flexibilidade da produção, do trabalho e do consumo foi, sob essa perspectiva, uma resposta para a natureza inflacionária da crise que começou a se manifestar em meados da década de 60 - ou seja, foram um resultado da busca de soluções financeiras. Isso implicaria, assinala Harvey, que "o sistema financeiro alcançou um grau de autonomia diante da produção real sem precedentes na história do capitalismo, levando este último a uma era de riscos financeiros igualmente inéditos". 204

\footnotetext{
${ }^{201}$ Idem, Ibidem, p. 155

${ }^{202}$ Idem, Ibidem, p. 157.

${ }^{203}$ Idem, Ibidem, p. 161.

${ }^{204}$ Idem, Ibidem, p. 181
} 
Diante dessa conjuntura histórica, faz-se necessário evidenciar que foi, sobretudo, a aliança entre a desvalorização do trabalho e o modo flexível de acumulação a responsável pela "salvação" do sistema econômico. A partir de então, o endividamento e a formação fictícia do capital se aceleraram, e a peculiaridadade da situação consistiu nos aspectos financeiros da organização capitalista e no crescente papel do crédito. No que tange às tranformações culturais, por fim, o geógrafo marxista conclui:

(...) O movimento mais flexível do capital acentua o novo, o fugidio, o efêmero, o fugaz e o contingente da vida moderna, em vez dos valores mais sólidos implantados na vigência do fordismo. Na medida em que a ação coletiva se tornou, em conseqüência disso, mais difícil - tendo essa dificuldade consistido, com efeito, a meta central do impulso de incremento do controle do trabalho -, o individualismo exacerbado se encaixa no quadro geral como condição necessária, embora não suficiente, da transição do fordismo para a acumulação flexível. Afinal de contas, foi principalmente por intermédio da irrupção da formação de novos negócios, da inovação e do empreendorismo que muitos dos novos sistemas de produção vieram a ser implementados. Entretanto, como Simmel (1978) sugeriu há muito tempo, é também nesses períodos de fragmentação e de insegurança econômica que o desejo de valores estáveis faz surgir uma ênfase intensificada na autoridade das instituições básicas - a família, a religião, o Estado. E há abundantes provas de um renascimento do apoio a essas instituições e aos valores por elas representados em todo o mundo ocidental desde mais ou menos $1970 .{ }^{205}$

Levando em consideração o contexto de contínua vida degradada no capitalismo tardio, surgiria o desejo de que a linguagem, a cultura e da arte e assumissem um certo lugar de autoridade e autonomia. Assim como o recurso regressivo à família, à religião e ao Estado vieram preencher uma necessidade por valores e instituições, o livre fluxo dos significantes descolados de seu significado e a hiperinflação estética talvez venham em socorro de uma experiência aparentemenete dissociada da produção e reprodução das condições materiais de existência.

${ }^{205}$ Idem, Ibidem, p. 162. 
Pois a falência da tradição liberal é tão evidente no nível filosófico como o é no politico: o que não significa que tenha perdido seu prestígio ou força ideológica.

(Fredric Jameson, Marxismo e Forma. )

A sociedade não existe; apenas homens e mulheres individuais.

(Margaret Thatcher apud David Harvey, O Neoliberalismo: história e implicações.)

\section{O Capitalismo Tardio e a lógica cultural de Jameson}

\subsection{O Neoliberalismo em foco: reflexões sobre sua abrangência}

Para fins de periodização, vale transpor um trecho de Harvey:

Os futuros historiadores poderão coerentemente ver os anos de 1978-80 como um ponto de ruptura revolucionário na história social e econômica do mundo. (...) Transformações desse alcance e dessa profundidade não ocorrem por acaso. Assim, é pertinente perguntar por que meios e percursos a nova configuração econômica - frequentemente designada pelo termo globalização - foi arrancada das entranhas da antiga. ${ }^{206}$

Nesse sentido, o autor enfatiza que as tecnologias e formas organizacionais flexíveis não se tornaram hegemônicas em toda parte - "mas o fordismo que as precedeu também não". ${ }^{207}$ Entretanto, apesar dos desenvolvimentos geográficos desiguais, a chamada "virada neoliberal" se tornou hegemônica no âmbito do capitalismo global ${ }^{208}$, e o pós-modernismo, talvez tenha se tornado a ideologia em segundo grau, para parafrasear Roberto Schwarz em As idéias fora do lugar, mesmo naqueles lugares onde a acumulação flexível não havia sido implementada.

O "compromisso de classe" estabelecido no período pós-segunda guerra entre o capital e o trabalho havia sido garantido, sobretudo, pela intervenção Estatal ativa, ora na política industrial (ao estabelecer padrões para o salário real), ora por meio da construção de sistemas de

\footnotetext{
${ }^{206}$ HARVEY, David. O Neoliberalismo: história e implicações. São Paulo: edições Loyola, 2008, p. 11.

${ }^{207}$ HARVEY, David. Condição pós-moderna. São Paulo: Edições Loyola, 2002, p. 179.

${ }^{208}$ HARVEY, David. O Neoliberalismo: história e implicações. São Paulo: edições Loyola, 2008, p 19.
} 
bem-estar, tais como saúde e educação. A política redistributiva era possibilitada ainda pelo planejamento liderado pelo Estado bem como da sua posse de alguns setores-chave da economia, como o carvão, o aço e os automóveis. O projeto neoliberal buscou desvencilhar o capital dessas restrições.

Depois dos traumas de 1973 - notadamente o desemprego e a inflação -, "a pressão pela desregulamentação nas finanças adquiriu impulso nos anos 70 e, por volta de 1986, engolfou todos os centros financeiros do mundo". ${ }^{209}$ O mundo capitalista mergulhou na neoliberalização como a resposta para uma série de experimentos que somente convergiram em uma nova ortodoxia em 1990, com a articulação do "Consenso de Washington".

Todavia, há um elemento na transição neoliberal que, na visão de Harvey, merece atenção específica. A neoliberalização pode ser interpretada como a restauração - em alguns casos criação - do poder de uma elite econômica, seja como resposta à ameaça política que a alternativa socialista trazia tanto em países avançados como em desenvolvimento, seja à ameaça econômica advinda da crise; sendo assim, segundo autor, "as classes altas tinham de agir com mais vigor para se proteger da aniquilação política e econômica". ${ }^{210}$

O acordo dos anos dourados pressupunha que na dinâmica entre o capital e o trabalho este último ficasse com a fatia majoritária do bolo economico; enquanto o crescimento se manteve estável, tal restrição não surtiu maiores objeções. Quando, com o colapso dos anos 70 as taxas de juros reais ficaram negativas e, por conseguinte, a taxa de lucro, "as classes altas em toda parte se sentiram ameaçadas". ${ }^{211}$

Cada vez mais livre dos termos regulatórios que até então limitavam seu campo de ação, a atividade financeira, a partir de então, pôde florescer e se expandir como jamais, e chegou a permear espaços outrora resguardados da sua influência. Em suma: "a neoliberalização significou a financialização de tudo (...). Houve, sem sombra de dúvida uma mudança de poder da produção para o mundo das finanças". ${ }^{212}$

\footnotetext{
${ }^{209}$ HARVEY, David. Condição pós-moderna. São Paulo: Edições Loyola, 2002, p. 152.

${ }^{210}$ Idem, Ibidem, p. 25.

${ }^{211}$ Idem, Ibidem, p. 25.

${ }^{212}$ HARVEY, David. O Neoliberalismo: história e implicações. São Paulo: edições Loyola, 2008, p. 42.
} 


\subsubsection{O debate acadêmico e seus primeiros efeitos}

O neoliberalismo como antídoto para as ameaças à ordem capitalista bem como para as mazelas econômicas foi fruto de experimentos e debates que, embora estivessem na pauta desde a implantação das práticas intervencionistas do pós-guerra, só passaram a ocupar a agenda política a partir da década de 70. A teoria neoliberal obteve respeitabilidade quando Hayek em 1974 e Friedman em 1976 ganharam o premio Nobel da economia. Contudo, observa Harvey, a “dramática consolidação do neoliberalismo como nova ortodoxia econômica de regulação da política pública no nível do Estado no mundo capitalista avançado ocorreu nos Estados Unidos e na Grã-Bretanha em 1979”. ${ }^{213}$

$\mathrm{O}$ rótulo neoliberal marcava a adesão aos princípios do livre mercado da economia neoclássica que emergiu na segunda metade do século XIX, ao revisitar as teorias clássicas de David Ricardo e Adam Smith. Não obstante, o recurso regulatório do mercado continuava a ser a "mão invisível", na medida em que proporcionava a mobilização "de mesmo os mais vis instintos humanos, como a gula, a ambição e o desejo de riqueza e poder em benefício de todos". 214

A ortodoxia do neoliberalismo pressupunha uma batalha não somente contra as idéias marxistas e socialistas, mas igualmente contra o planejamento estatal e o intervencionismo keynesiano. Isso envolvia, assinala Harvey, enfrentar o poder sindical e seus ideais de coletividade que pudessem ser prejudiciais à desejada flexibilidade competitiva. No tocante ao Estado, equivalia a desmantelar os compromissos de bem-estar social, privatizar empresas públicas, reduzir impostos, promover o empreendedorismo para a criação do "clima de negócios favorável" e, desse modo, atrair investimentos externos. As formas tradicionais de solidariedade social deveriam ser dissolvidas em prol do individualismo, da propriedade privada e dos valores familiares.

Nesse horizonte, o efeito da prática neoliberal sobre a condição do trabalho foi substancial. O salário mínimo federal, durante o governo Reagan, caiu drasticamente, e terminou sua queda por volta dos anos 90: “iniciou-se assim, com vigor, o longo declínio dos níveis de

${ }^{213}$ HARVEY, David. O Neoliberalismo: história e implicações. São Paulo: edições Loyola, 2008, p. 31.

${ }^{214}$ Idem, Ibidem, p. 30. 
salário real (...) a abissal mudança para uma desigualdade social cada vez maior e a restauração do poder econômico da classe alta". ${ }^{215}$

Soma-se ainda o fato de que a desregulação monetária abriu novas áreas de liberdade para a realização dos interesses corporativos em escala multinacional; assim sendo, o capital passou a ser investido em lugares onde a taxa de retorno fosse mais elevada (sobretudo fora dos países avançados, como os EUA), o que acarretou o processo de desindustrialização doméstica e a tendência a levar a produção para o exterior. O mercado, "descrito ideologicamente como forma de promover a competição e a inovação, tornou-se veículo da consolidação do poder monopolista". ${ }^{216}$

No que concerne aos países em desenvolvimento, além de terem fornecido mão-de-obra e matéria-prima baratas, bem como taxas de imposto sobre a produção favoráveis, estavam estes ainda "ansiosos o bastante para se endividar". Nesse contexto, os fundos excedentes dos bancos de investimento de NovaYork se dispersaram pelo globo; vale ressaltar que estes bancos, segundo Harvey, sempre tinham sido ativos no plano internacional. Depois de 1973, contudo, a prática se acentuou, concentrando-se no fornecimento de recursos financeiros a governos estrangeiros.

Finalmente, é necessário apontar para uma diferença essencial entre a prática liberal e neoliberal. Naquela, acentua Harvey, os que emprestam assumem as perdas oriundas das decisões de investimento, enquanto nesta são os devedores que as fazem, forçados pelo Estado e por forças internacionais a assumir o ônus do custo do pagamento da dívida, "sejam quais forem as conseqüências para a vida e para o bem-estar da população local”. Nesse sentido, pode-se dizer que a "restauração do poder a uma elite econômica ou classe apoiou-se pesadamente em mais-valia extraída do resto do mundo por meio de fluxos internacionais e práticas de ajuste estrutural” ${ }^{217}$, a chamada divisão internacional do trabalho.

\footnotetext{
${ }^{215}$ Sobre este assunto, vale apontar para algumas cifras a fim de mensurar o impacto das medidas em questão: “o patrimônio líquido das 358 pessoas mais ricas do mundo em 1996 foi igual a 'renda combinada dos 45\% mais pobres da população mundial - 2,3 bilhões de pessoas'. E dobraram seu patrimônio líquido, nos quatro anos anteriores a 1998, para mais de 1 trilhão de dólares. Os ativos dos três maiores bilionários alcançavam na época um valor superior ao PIB de todos os países menos desenvolvidos e sua população de 600 milhões de pessoas". HARVEY, David. O Neoliberalismo: história e implicações. São Paulo: edições Loyola, 2008, p. 34, 35, 43.

${ }^{216}$ Idem, Ibidem, p. 35.

${ }^{217}$ Idem, Ibidem, p. 38.
} 


\subsection{O particular elevado ao universal: a crise fiscal de Nova York e o governo de Reagan}

Sobre o modo de construção do consentimento do sistema neoliberal - necessário para sua legitimação -, vale destacar, inicialmente, as observações de Harvey:

Aquilo que Gramsci denomina senso comum (definido como "o sentido sustentado em comum") tipicamente fundamenta o consentimento. O senso comum é construído com base em práticas de longa data de socialização cultural que costumam fincar profundas raízes em tradições nacionais ou regionais. Não é o mesmo que bom senso, que pode ser construído a partir do engajamento crítico com as questões do momento. Assim sendo, o senso comum pode ser profundamente enganoso, escamoteando ou obscurecendo problemas reais sob preconceitos culturais. (...) A palavra liberdade ressoa tão amplamente na compreensão de senso comum que têm os norte-americanos que se tornou 'um botão que as elites podem pressionar para abrir a porta às massas' a fim de justificar quase qualquer coisa. Foi assim que Bush pôde justificar retrospectivamente a guerra do Iraque. Gramsci concluiu (...) que as questões políticas, quando "disfarçadas como culturais", se tornam "insolúveis". Parece ser o caso do pósmodernismo. $^{218}$

Com o propósito de melhor identificar as bases materiais da contrução deste consentimento, é necessário examinar, para além dos mecanismos culturais e ideológicos, “as qualidades da experiência cotidiana" sob o capitalismo a partir da década de 1970. Desse modo, tem-se a compreensão de como o neoliberalismo penetrou no senso comum e tornou-se uma "maneira necessária e natural de regular a ordem social",;19 ou seja, o modo como se tornou ideologia, fazendo o certo encanto da mercadoria: promessas extremas, realizações impossíveis.

A fusão das metas de liberdade individual e justiça social forjada, sobretudo nos movimentos estudantis de maio de 68, foi o pontapé inicial para a construção desse consentimento. A tensão inerente entre os valores almejados se mostrou problemática na medida em que a busca de justiça social demanda a propensão a submeter vontades e desejos a uma causa maior. O resultado dessa tensão, sob as condições materiais de produção e reprodução da vida no capitalismo tardio fez a balança pender para o hedonismo. Como assinala Harvey, o neoliberalismo não criou essas distinções, mas pôde explorá-las e fomentá-las.

${ }_{218}^{218}$ HARVEY, David. O Neoliberalismo: história e implicações. São Paulo: edições Loyola, 2008, p. 49.

${ }^{219}$ Idem, Ibidem, p. 50. 
No início dos anos 70 havia ainda uma causa comum que unia as reinvindicações estudantis e a esquerda tradicional (entendida como o trabalho organizado e os vínculos políticos favoráveis às solidariedades sociais): as corporações - respaldadas pelos governos dos países avançados - e suas práticas predatórias ao meio ambiente e incitação ao consumo irracional.

O Estado, sob essa perspectiva, mostrava-se cada vez mais incapaz de resolver os problemas sociais e de responder, ao mesmo tempo, às demandas da diversidade: "os direitos civis eram um problema, e as questões da sexualidade e dos direitos reprodutivos estavam na ordem do dia". ${ }^{220}$ A retórica neoliberal, com sua ênfase nas liberdades individuais, no multiculturalismo e no consumismo narcisista transformou a busca da justiça social em fragmentadas lutas civis - a política de identidades - quando da conquista do poder estatal. Sendo assim, o neoliberalismo acabou por se apoiar em uma estratégia prática que

(...) Enfatizasse a liberdade de escolha do consumidor, não só quanto a produtos particulares, mas também quanto a estilos de vida, formas de expressão e uma ampla gama de práticas culturais. A neoliberalização precisava, política e economicamente, da construção de uma cultura populista neoliberal fundada no mercado que promovesse o consumismo diferenciado e o libertanismo individual. No tocante a isso, ela se mostrou mais que compatível com o impulso cultural chamado "pós-modernismo", que havia muito espreitava no ninho, mas agora podia surgir, emplumando, como dominante tanto cultural quanto intelectual. ${ }^{221}$

O modo como o poder do Estado foi empregado, e remoldou as compreensões do senso comum para fins de legitimação do neoliberalismo pode ser vislumbrado a partir da resposta dada à crise política e econômica dos anos 70, especialmente à crise fiscal de Nova York. Segundo Harvey, o modo como o impasse foi administrado abriu pioneiramente o caminho para as práticas neoliberais tanto domesticamente, sob Reagan, como internacionalmente, por meio do FMI na década de 1980.

A “crise urbana" (ocorrida igualmente em muitas outras cidades norte-americanas) se deu, a priori, em decorrência da reestruturação capitalista e da desindustrialização crescente, que terminaram por impactar a base econômica da cidade e deixar o centro empobrecido, ao passo que o fenômeno da suburbanização havia aumentado consideravelmente. A solução momentânea

\footnotetext{
${ }^{220}$ HARVEY, David. O Neoliberalismo: história e implicações. São Paulo: edições Loyola, 2008, p. 51-52.

${ }^{221}$ Idem, Ibidem, p. 52.
} 
foi a expansão do emprego e serviço públicos, facilitada à época por recursos federais. No começo da década de 70, o então presidente Nixon declarou que a crise urbana acabara e reduziu a ajuda federal. Por um tempo as instituições financeiras supriram a carência de capital, mas em 1975 um grupo de banqueiros cortou os investimentos, o que levou a cidade à derrocada.

Para salvar Nova York foram criadas instituições que assumiram a administração do orçamento da cidade; como decorrência, tinham total liberdade de gestão das receitas de impostos e destinavam o dinheiro primeiramente para o pagamento dos acionistas. Apenas o que sobrasse poderia ser utilizado em serviços essenciais - ou seja, as conhecidas medidas de austeridade. $\mathrm{O}$ efeito disso "foi jogar por terra as aspirações dos fortes sindicatos municipais, implementar congelamentos de salário e cortes no emprego público e na manutenção de serviços sociais (educação, saúde pública, serviços de transporte)". ${ }^{222}$ Dessa forma, foram enfraquecidas as bases sociais da luta e da resistência, o que - de maneira míope e simplificada - acabou servindo como um dos pilares para o discurso pós-moderno do fim da luta de classes. Noutras palavras, a prática política fragmentou conquistas de uma tradição de combate da classe trabalhadora e o discurso de viés culturalista assumiu tal fragmentação quase que como um dado natural, portanto, imutável.

Por conseguinte, constata-se que, em meio a uma crise fiscal, foi feita uma distribuição da riqueza favorável às classes altas. $\mathrm{O}$ bem-estar social deu lugar ao bem-estar corporativo. A cidade passou a ser concebida paulatinamente como uma entidade empreendedora, ao invés de social e democrática. Nesse ambiente, tanto o governo como a classe trabalhadora (e o movimento trabalhista por extensão) foram privados de uma parcela do poder que haviam conquistado nas três décadas precedentes.

As instituições da elite nova iorquina se empenharam, igualmente, em vender a imagem da cidade como o centro cultural e turístico. Sob essa ótica, promoveram a abertura do campo cultural a uma gama de diferentes correntes cosmopolitas:

A exploração narcisista do ego, da sexualidade e da identidade se tornou um leitmotiv da cultura burguesa urbana. A liberdade e a licença artísticas, promovidas pelas poderosas instituições culturais da cidade, levaram à neoliberalização da cultura. (...) A Nova York delirante (...) apagou a memória coletiva da Nova

${ }^{222}$ HARVEY, David. O Neoliberalismo: história e implicações. São Paulo: edições Loyola, 2008, p. 55. 
York democrática. (...) Nova York se tornou o epicentro da experimentação cultural e intelectual pós-moderna. ${ }^{223}$

A maneira de enfrentar a crise fiscal da big Apple se tornou paradigmática ao estabelecer o princípio de que, quando da existência de conflitos entre as instituições financeiras e o bemestar dos cidadãos, os interesses daquela deveriam prevalecer. Desse modo, enfatizou o papel do governo quanto à criação de um clima favorável aos negócios, em detrimento do bem-estar da população em geral. Ao mesmo tempo, a transposição das soluções locais para o nível nacional foi acentuada, e a política do governo Reagan nos anos 1980 foi o cenário de Nova York dos anos 70 ampliado.

Foi ainda durante o mandato de Reagan que o trabalho organizado e as relações trabalhistas foram neutralizados para serem adequados à nova ordem social. Ao desmontar o sindicato dos controladores de vôo em 1981, o presidente deixou claro que os sindicatos em geral não eram bem-vindos, muito menos como participantes dos conselhos internos do governo, como haviam sido outrora. Em resumo: “a difícil relação social que prevalecera entre o poder corporativo e o poder sindical dos anos 1960 desapareceu". ${ }^{224}$

De um lado a alta taxa de desemprego alcançada em meados de 1980 bem como a desindustrialização das regiões industriais centrais (essenciais para o trabalho organizado) antes sindicalizadas enfraqueceram o poder de barganha dos trabalhadores. De outro, as vantagens oferecidas aos trabalhadores individualmente destruíam o esquema da ação coletiva. Harvey constata que as regras rígidas e estruturas burocráticas dos sindicatos os tornaram vulneráveis aos ataques promovidos ora pelo governo, ora pelo capital.

Nesse cenário, as reinvindicações de especialização flexível nos processos de trabalho e a flexibilização dos contratos tornaram-se instrumentos de manobra neoliberal, persuasivas o bastante para trabalhadores individuais, notadamente aqueles que haviam sido excluídos dos benefícios da sindicalização. Cabe ressaltar que a liberdade (em geral ou no mercado de trabalho) foi louvada como grande virtude - tanto para o capital como para o trabalho - e alcançou statuto de máxima do sistema, fazendo, assim, com que os valores neoliberais fossem integrados ao senso comum inclusive da força de trabalho.

\footnotetext{
${ }^{223}$ Sobre o assunto, Harvey explica ainda que havia divergências mesmo entre as elites da cidade; estas aceitaram, "não sem relutância ativa, a exigência de diversificação de estilos de vida (incluindo os relativos às preferências sexuais e ao gênero) e de aumento constante das opções de nichos de consumidores (em áreas como a produção cultural). Idem, Ibidem, p. 57.

${ }^{224}$ Idem, Ibidem, p. 62.
} 


\subsubsection{O caso da Grã-Bretanha e Margaret Thatcher}

O Estado do bem-estar social construído na Grã-Bretanha depois da Segunda Guerra Mundial era dotado de uma estrutura "bem mais elaborada e abrangente do que se sonhou algum dia nos Estados Unidos", e, como observa Harvey, "nunca agradou a todos os setores". ${ }^{225}$ Correntes de crítica circulavam na mídia, com a intenção de promover, sobretudo, os interesses financeiros. O individualismo, a liberdade de iniciativa e a liberdade de expressão permeavam os meios subterrâneos do pensamento e eram concebidos como opostos à burocracia e à rigidez do aparato estatal bem como do poder sindical.

Tais críticas se disseminaram no país durante a década de 60 e foram intensificadas a partir da estagnação econômica da década seguinte. A estrutura tradicional das redes de relação e poder foi questionada, o individualismo e a liberdade de expressão alçaram voo como idéias radicais, em contraposição ao status quo. Houve ainda um movimento jovem, à semelhança de maio de 68, que mantinha uma atitude hostil e insolente com respeito aos privilégios de classe cujas reivindicações vieram a ser a base ulterior da virada pós-moderna.

Não obstante, Harvey enfatiza que embora houvesse elementos para a construção do consenso em direção ao neoliberalismo, o determinante fora a crise de acumulação de capital da década de 70 na medida em que a estagflação prejudicava a todos. Em 1975, a inflação disparou para $26 \%$ e o desemprego chegou a 1 milhão de pessoas. ${ }^{226}$

Foi nesse mesmo período em que a famosa greve dos mineiros britânicos ocorreu, primeiramente em 1972, depois em 1974, quando o governo declarou estado de emergência ao mesmo tempo em que procurava obter apoio público na batalha travada contra os trabalhadores. Convocadas eleições, a vitória foi do partido trabalhista, que voltou ao poder e negociou a greve em termos favoráveis aos mineiros.

Com efeito, o nó górdio da situação residia no fato do governo trabalhista não ter condições de sustentar os déficits orçamentários e ser obrigado a recorrer, em 1975-76, ao FMI. Nesse momento, as alternativas passaram a ser submeter-se aos ditames das restrições e austeridade ou declarar falência, "sacrificando a integridade da libra e ferindo de morte os

\footnotetext{
${ }^{225}$ HARVEY, David. O Neoliberalismo: história e implicações. São Paulo: edições Loyola, 2008, p. 66.

${ }^{226}$ Idem, Ibidem, p. 67.
} 
interesses da City of London (...) o mais importante resíduo da presença imperial britânica" ${ }^{227}$. A escolhida foi a primeira opção, o que resultou em drásticos cortes na esfera dos gastos sociais.

Nesse horizonte, o poder do trabalho enfraqueceu. Em 1984, Thatcher provocou a greve dos mineiros ao anunciar uma reestruturação do trabalho e, principalmente, o fechamento de minas, uma vez que o carvão importado era mais barato. A greve durou quase um ano e, apesar do apoio público e da simpatia dos ingleses, os mineiros saíram como perdedores. Nas palavras de Harvey, "a espinha dorsal de um elemento nuclear do movimento trabalhista britânico fora quebrada. (...) O efeito geral, em apenas dez anos, foi o de transformar o Reino Unido num país de salários relativamente baixos e força de trabalho relativamente obediente (...)". ${ }^{228}$ Vale dizer que o poder sindical foi igualmente reduzido pela abertura aos investimentos externos, que demoliu uma grande parcela da indústria nacional, principalmente a do aço e a automobilística.

Com efeito, a ministra erradicou a inflação, controlou o poder sindical (por meio da dominação da força de trabalho) e privatizou todos os setores da economia outrora nas mãos do Estado inglês. A receita das transações encheu os cofres públicos e ainda livrou o governo de obrigações futuras.

Para além do objetivo pecuniário, a finalidade das privatizações era modificar a cultura política, ao ampliar os campos da responsabilidade pessoal e corporativa, estimular a eficiência, a iniciativa empreendedora e a inovação. A legitimação do imperativo de privatizar se deu, também, com o sucesso na venda de habitações públicas, que teve o efeito de aumentar significativamente o número de proprietários em apenas uma década. Isso, comenta Harvey, satisfez os ideais tradicionais da propriedade individual e, por conseguinte, introduziu um dinamismo no mercado imobiliário, favorecendo ainda a especulação.

O que houve em comum nos casos britânicos e americanos, cabe destacar, residiu, sobretudo, na maneira de combater as relações de trabalho e a inflação. Todavia, o "mérito" de ambos foi transformar posições políticas, ideológicas e intelectuais que eram minoritárias em majoritárias: a aliança de força que eles ajudaram a consolidar tornou-se um legado cujos políticos posteriores tiveram “dificuldades para desalojar". E, uma vez posto em movimento, o neoliberalismo se tornou "tão penetrantemente arraigado no mundo de fala inglesa, [que] ficou difícil tirar dele considerável relevância que adquirira no tocante a como o capitalismo em geral

${ }^{227}$ HARVEY, David. O Neoliberalismo: história e implicações. São Paulo: edições Loyola, 2008, p. 66, 68.

${ }^{228}$ Idem, Ibidem, p. 69. 
passou a funcionar internacionalmente. Isso não significa dizer (...) que o neoliberalismo foi simplesmente imposto alhures pela influência do poder anglo-americano". ${ }^{229}$

\subsection{O desenvolvimento desigual do neoliberalismo ao redor do globo}

O progresso da neoliberalização se deu por mecanismos de desenvolvimento geográfico desiguais. Os países que compunham a vanguarda da acumulação de capital pressionavam os demais a seguir seus exemplos e, nesse sentido, o Reino Unido e os Estados Unidos foram os líderes, embora em nenhum deles a virada tenha deixado de apresentar problemas nem tenha solucionado de vez as questões econômicas durante os anos 80 . É fato que a inflação baixou e a taxa de juros aumentou, mas o preço pago foi a alta do desemprego. Com os cortes em benefícios sociais e em despesas com infra-estrutura, a qualidade de vida foi reduzida, e "o resultado geral foi uma estranha mistura de baixo crescimento e crescente desigualdade de renda". ${ }^{230}$

$\mathrm{Na}$ década de 80 foram os chamados "tigres Asiáticos" assim como a Alemanha Ocidental as economias com mais força competitiva no âmbito global. Os modelos adotados em ambos países não incluíam as louvadas reformas neoliberais, o que tornou difícil alegar que a neoliberalização progrediu, no cenário mundial, como medida paliativa comprovada para a estagnação econômica. De acordo com Harvey, na Alemanha Ocidental os sindicatos se mantiveram ativos, o que preservou as garantias sociais e o nível dos salários. Em conseqüência, a inovação tecnológica foi estimulada, as exportações aumentaram, e o país se manteve na dianteira da corrida oitentista, ainda que tenha gerado desemprego por conta da automação.

O Japão, pelo contrário, não possuía tradição sindical e a exploração do trabalho era uma realidade; o que fomentou sua disparada foi, essencialmente, o investimento do Estado em tecnologia e as estreitas relações entre as corporações e os bancos (ocorrida igualmente na Alemanha Ocidental), que possibilitou o crescimento voltado para a exportação. Nesse sentido, o crescimento nos anos 80 "não dependeu da neoliberalização exceto no sentido mais restrito de que uma maior abertura do comércio e dos mercados globais proporcionou o contexto no qual histórias de sucesso do Japão, da Alemanha Ocidental e dos tigres asiáticos puderam ocorrer

\footnotetext{
${ }^{229}$ HARVEY, David. O Neoliberalismo: história e implicações. São Paulo: edições Loyola, 2008, p. 72.

${ }^{230}$ Idem, Ibidem, p. 98.
} 
(...)". ${ }^{231}$ Ironicamente, os países que haviam seguido as exigências neoliberais não eram os que haviam promovido taxas satisfatórias de crescimento.

Entretanto, tais modelos adotados não facilitavam a restauração do poder de classe. Se o projeto neoliberal visava, segundo tese de Harvey, a retomada do poder pelas elites, então suas práticas econômicas eram as que se prestavam mais eficazmente ao objetivo; a "possibilidade ou não de um país ser levado à neoliberalização dependia do balanço de forças entre as classes, (...) bem como do grau de dependência da classe capitalista em relação ao Estado. (...)". ${ }^{232}$

De fato, foi somente na década de 90 que as tendências do modelo econômico neoliberal se consolidaram e o poder de classe foi enfim restaurado. Nesse processo, quatro componentes foram essenciais: primeiramente, a financeirização, iniciada em 70, acelerou-se; "o investimento externo direto e o investimento indireto aumentaram rapidamente por todo o mundo capitalista (...) e passaram assim a ser os recursos privilegiados de restauração do poder de classe”. Em seguida, e em conseqüência da desregulação dos mercados financeiros, bem como das inovações em comunicação, foi intensificada a mobilidade geográfica do capital: a paulatina redução de barreiras artificiais ao movimento do capital e das mercadorias, como as tarifas, os controles de câmbio também desempenharam um importante papel. O impulso geral para a padronização que facilitaria as trocas globais se deu com a ratificação dos acordos firmados na Organização Mundial do Comércio, que passaram a vigorar em 1995. ${ }^{233}$

Em terceiro, a flexibilidade nos mercados de trabalho e a redução de gastos com o bemestar social começaram a "compensar", e passaram a pressionar os mercados mais rígidos que prevaleciam em boa parte da Europa, exceto na Inglaterra e no Japão. No entanto, foi o fluxo de tributos oriundo das altas taxas de retorno, extraído, cabe destacar, do resto mundo, o que sustentou a competitividade alcançada nos Estados Unidos durante a década de 90.

Por fim, a gradativa expansão da "nova ortodoxia neoliberal e monetarista" passou a exercer uma influência ideológica cada vez maior; no final da década de 90, a economia keynesiana, já expurgada, deu lugar ao programa neoliberal, e uma parcela majoritária das pesquisas nos departamentos das universidades da América do Norte estavam voltadas para o

\footnotetext{
${ }^{231}$ Idem, Ibidem, p. 98.

${ }^{232}$ Idem, Ibidem, p. 99.

${ }^{233}$ David Harvey observa ainda que "como o grau de neoliberalização estava sendo cada vez mais considerado pelo FMI e pelo Bando Mundial uma medida de bom clima de negócios, houve um incrível aumento da pressão sobre todos os Estados para que adotassem reformas neoliberais". Idem, Ibidem, p. 100.
} 
estudo e a aplicação do programa neoliberal, calcado, sobretudo, no controle da inflação e na solidez das finanças públicas, em detrimento do pleno emprego e das proteções sociais.

Uma última consideração, pois, faz-se necessária: para Harvey, a destruição violenta das formas do trabalho organizado foi a precondição para a virada neoliberal; "na medida em que o trabalho logrou manter ou adquirir (...) uma forte presença, a neoliberalização enfrentou barreiras sólidas e em alguns casos intransponíveis". ${ }^{234}$ O grau em que foi incorporada ao senso comum da população dependeu da crença - ou não - no poder das solidariedades sociais e na tradição da responsabilidade e provisão coletivas.

\subsection{Quaisquer contradições do Estado Neoliberal}

Conforme a teoria neoliberal, o papel do Estado é o de garantir a propriedade privada e o regime de direito, criar insituições de mercados de livre funcionamento e de livre comércio. Por conseguinte, pode-se dizer que "as liberdades que ele encarna refletem os interesses dos detentores de propriedade privada, dos negócios, das corporações multinacionais e do capital financeiro". 235

Se são as liberdades individuais suas premissas máximas, então o arcabouço legal que as sustentam são os contratos e as obrigações advindas do acordo entre as partes. O Estado, e somente ele, detém os meios coercitivos para se fazer cumprir as obrigações adquiridas, a fim de proteger a liberdade de ação, de expressão e de escolha. O bem fundamental é a liberdade dos negócios e, sob esse prisma, são as corporações igualmente consideradas legalmente como indivíduos. A produção de riqueza, sob a retórica do neoliberalismo, é gerada por meio da iniciativa dos empreendedores - em suas empresas privadas -, e a "inovação é alma do negócio".

Por extensão, os direitos de propriedade intelectual, especificamente no tocante às patentes, são a pedra de toque para estimular as mudanças tecnológicas e, ao final, os aumentos da produtividade proporcionariam um padrão de vida mais elevado a todos; "sob o pressuposto que 'uma maré montante faz subir todos os barcos' (...) a teoria neoliberal sustenta que a

\footnotetext{
${ }^{234}$ Idem, Ibidem, p. 126.
}

${ }^{235}$ Idem, Ibidem, p. 30. 
eliminação da pobreza pode ser mais bem garantida através dos livres mercados e do livre comércio". ${ }^{236}$

Pois a competição sendo a virtude principal, estimulada pela privatização e desregulação, deveria ela então dar conta de eliminar os "entraves burocráticos" e assim aumentar a eficiência e a produtividade - o que melhoraria a qualidade e reduziria os custo e seria positivo para ambos, produtor e consumidor. Contudo, o risco inerente à competição é que ela se torne monopólio ou oligopólio, e, no contemporâneo, em escala global, ficando a concentração econômica na mão de umas poucas corporações multinacionais centralizadas: "o mundo da competição de refrigerantes se reduz a Coca-Cola versus Pepsi, (...) e uns poucos magnatas da mídia controlam o fluxo de notícias, boa parte das quais se torna pura propaganda". ${ }^{237}$

O poder cada vez maior das corporações no âmbito mundial atesta a insuficiência do indivídio isolado frente ao mercado tanto no ambiente de trabalho como no espaço vital. A falta de simetria nas relações entre as corporações e os sujeitos individuais permite apontar para a distância entre a teoria e as práticas neoliberais: se é possível sustentar que o "poder corporativo rouba sua liberdade pessoal, o neoliberalismo se reduz a nada". ${ }^{238}$

No horizonte neoliberal, embora as liberdades sejam asseguradas, cada indivíduo é julgado responsável por suas ações e bem-estar, e responde por eles, e o sucesso ou fracasso são interpretados em termos de virtudes empreendedoras ou de falhas pessoais em vez de atribuídos a alguma propriedade do sistema ou às condições de sobrevivência.

Conforme salienta Terry Eagleton, o que há de errado no desinteresse do Estado Liberal "não reside no fato de ele mascarar de modo especioso algum interesse, mas de cultuar explicitamente um: o interesse de suma importância da escolha individual". Segue-se que se os direitos individuais incluem de modo central os direitos de propriedade privada, tal modalidade de Estado acaba por gerar "precisamente os tipos de desigualdade e exploração que subvertem a busca do bem-estar que ele deveria promover. Com efeito, nem todos estarão de posse dos bens necessários para traçar o próprio caminho para a felicidade". ${ }^{239}$

No tocante ao cenário das trocas globais, o projeto do neoliberalismo pressupõe a livre mobilidade do capital entre setores, regiões e países como peça chave na interação do sistema

\footnotetext{
${ }^{236}$ Idem, Ibidem, p. 75.

${ }^{237}$ Idem, Ibidem, p. 90.

${ }^{238}$ Idem, Ibidem, p. 90.

${ }^{239}$ EAGLETON, Terry. As Ilusões do pós-modernismo. Rio de Janeiro: Zahar, 1998, p. 83.
} 
econômico. As barreiras, com relação às tarifas compensatórias, sobretaxas, planejamento e controle ambiental - ou qualquer outro impedimento de natureza local - devem ser removidas, “exceto em áreas de interesse nacional, como quer que esse seja definido". ${ }^{240}$ Neste quesito, espera-se que o Estado assuma uma função secundária, restringindo-se a montar um ambiente favorável para os negócios, e acordos internacionais são travados de modo a garantir o regime de direito e as liberdades do comércio, como a OMC (todavia, vale lembrar, é permitido ao Estado a imposição arbitrária de restrições a importações para acalmar investidores domésticos).

Ora, se a soberania estatal passa para seguno plano com relação aos movimentos de mercadoria e de capital, tem-se que ela "é entregue de bom grado ao mercado global". No entanto, o poder estatal é por vezes utilizado para resgatar empresas ou evitar desastres financeiros: "é difícil justificar essa prática seguindo a teoria neoliberal, já que os investidores deveriam em princípio ser responsáveis por seus próprios erros". ${ }^{241}$

Cabe destacar, conforme observa Harvey, que "os teóricos neoliberais têm uma profunda suspeita com relação à democracia. A governança pelo regime da maioria é considerada uma ameaça potencial aos direitos individuais e às liberdades constitucionais”. Como resposta, dão preferência às decisões do executivo ou judiciais, e o braço coercitivo do Estado acaba sendo fortalecido, para fins de proteção aos interesses corporativos (e, se necessário, para manutenção da ordem). O acesso à justiça, muito embora nominalmente igualitário, é na verdade uma operação custosa, em que "o resultado é em geral bastante favorável a quem detém o poder do dinheiro. Seja como for, o vício de classe das decisões judiciais é bem disseminado, quando não garantido de antemão". Harvey alega ainda que "o Estado produz tipicamente legislação e estruturas regulatórias que privilegiam as corporações". ${ }^{242}$

A disparidade maior, finalmente, reside no confronto entre as metas públicas declaradas do neoliberalismo, organizadas sob o titulo "bem-estar de todos", e "suas conseqüências concretas - a restauração do poder de classe". ${ }^{243}$ Ao contrário do que a retórica afirma, das palavras que soam virtuosamente como positivas, como a liberdade de ação, liberdade de

\footnotetext{
${ }^{240}$ HARVEY, David. O Neoliberalismo: história e implicações. São Paulo: edições Loyola, 2008, p. 76.

241 "Nunca fez muito sentido falar de uma classe capitalista distintintamente norte-americana versus uma britânica, francesa, alemã ou coreana. Os vínculos internacionais sempre foram importantes, especialmente através de atividades coloniais e neocoloniais, mas também por meio de ligações transnacionais que remontam ao século XIX, se não foram ainda mais antigas. Não há, contudo, dúvidas de que houve uma ampliação dessas ligações transnacionais durante a fase de globalização neoliberal (...)" Idem, Ibidem, p. 44, 83.

${ }^{242}$ Idem, Ibidem, p. 87, 88.

${ }^{243}$ Idem, ibidem, p. 89.
} 
pensamento, escolhas e direitos, “(...) a neoliberalização só pode funcionar com um Estado forte, um mercado forte e instituições legais". ${ }^{244}$ Então, pode-se sugerir que, sob a aparente fluidez e instabilidade da retórica pós-moderna - uma das faces ideológicas do neoliberalismo - reside um substrato de instituições e mecanismos bastante tradicionais: do Estado como gestor dos negócios da burguesia.

${ }^{244}$ HARVEY, David. O Neoliberalismo: história e implicações. São Paulo: edições Loyola, 2008, p. 129. 
Do mesmo modo que não se julga o indivíduo pela ideia que de si mesmo faz, tampouco se pode julgar uma tal época de transformação pela consciência que ela tem de si mesma. (Karl Marx, Contribuição à crítica da economia política.)

Identificar a cultura unicamente com a mentira é mais fatal no momento em que aquela de fato passa inteiramente para esta e provoca sôfrega essa identificação para comprometer todo e qualquer pensamento resistente. (...) Que a cultura tenha falhado até hoje não é justificativa para promover o seu fracasso como faz o gato do conto, que espalha toda a bela farinha de trigo sobre a cerveja derramada.

(Theodor Adorno, Mínima Moralia.)

\title{
3.5 A fusão da base com a superestrutura e o pós-modernismo como dominante cultural
}

Posto o campo de forças em que se move o sistema neoliberal, cabe perguntar: quais são as conseqüências culturais do domínio de "semelhante ética do mercado"? Conforme assinala Harvey,

\begin{abstract}
Nenhum modo de pensamento se torna dominante sem propor um aparato conceitual que mobilize nossas sensações e nossos instintos, nossos valores e nossos desejos, assim como as possibilidades inerentes ao mundo social que habitamos. Se bem sucedido, esse aparato conceitual se incorpora a tal ponto ao senso comum que passa a ser tido por certo e livre de questionamento. As figuras fundadoras do pensamento neoliberal consideravam fundamentais os ideais políticos da dignidade humana e da liberdade individual, tomando-os como os valores centrais da civilização. Assim agindo, fizeram uma sábia escolha, porque esses certamente são ideais bem convincentes e sedutores. Esses valores, sustentavam essas figuras, estavam ameaçados não somente pelo fascismo, pelas ditaduras e pelo comunismo, mas também por todas as formas de intervenção de Estado que substituíssem os julgamentos de indivíduos dotados de livre escolha por juízos coletivos. ${ }^{245}$
\end{abstract}

Ora, se a liberdade humana - e de escolha - é a máxima da pós-modernidade, vale salientar que a liberdade desse indivíduo é um produto histórico; como descreve Marx, somente ao chegar ao século 18 e na "sociedade burguesa é que as diferentes formas das relações sociais

${ }^{245}$ HARVEY, David. O Neoliberalismo: história e implicações. São Paulo: edições Loyola, 2008, p. 15. 
se erguem diante do indivíduo como um simples meio para seus fins privados, como uma necessidade exterior. (...) É a época que produz esse ponto de vista, do indivíduo isolado (...)”. ${ }^{246}$ Esse indivíduo como produto histórico encontra-se diretamente ligado ao modo de produção da vida material; em resumo, de acordo com a tese de Marx,

\begin{abstract}
Na produção social da própria existência, os homens entram em relações determinadas, necessárias, independentes da sua vontade; essas relações de produção correspondem a um grau determinado de desenvolvimento de suas forças produtivas materiais. A totalidade dessas relações de produção constituía a estrutura econômica da sociedade, a base real sobre a qual se eleva uma superestrutura jurídica e política e à qual correspondem formas sociais determinadas de consciência. $\mathrm{O}$ modo de produção da vida material condiciona o processo de vida social, política e intelectual. Não é a consciência dos homens que determina o seu ser; ao contrário, é o seu ser social que determina sua consciência. ${ }^{247}$
\end{abstract}

As mudanças operadas na base econômica na virada para o neoliberalismo transformaram "mais ou menos rapidamente toda a colossal superestrutura", uma vez que esta não tem história própria. Sendo assim, "convém distinguir sempre a transformação material das condições econômicas de produção (...) e as formas jurídicas, políticas, religiosas, artísticas ou filosóficas. (...) É preciso (...) explicar a consciência pelas contradições da vida material (...)" ${ }^{248}$. É nesse sentido, pois, que a categoria central para o pensamento dialético é a contradição, e a análise essencial a ser feita, para Marx, é a do conflito existente entre as forças produtivas sociais ${ }^{249}$ e as relações de produção. Neste horizonte, tal antagonismo na pós-modernidade se dá nos termos acima descritos, de acordo com o paradigma do neoliberalismo.

Nos termos de Marx, ainda, há que se diferenciar produção geral, ramos da produção particulares e a totalidade da produção. Ele estabelece uma dialética intrínseca entre produção e

\footnotetext{
${ }^{246}$ MARX, Karl. Contribuição à crítica da Economia Política. São Paulo: Expressão Popular: 2008, p. 239.

${ }^{247}$ Idem, Ibidem, p. 47.

${ }^{248}$ A esse respeito, explica ainda Marx: "Em uma certa etapa de seu desenvolvimento, as forças produtivas materiais da sociedade entram em contradição com as relações de produção existentes, ou, o que não é mais que sua expressão jurídica, com as relações de propriedade no seio das quais elas se haviam desenvolvido até então. De formas evolutivas das forças produtivas que eram, essas relações convertem-se em entraves. Abre-se, então, uma época de revolução social". SADER, Emir, Jinkings Ivava. As armas da crítica: antologia do pensamento de esquerda. São Paulo: Boitempo, 2012, p.106.

249 "Uma força de produção significa qualquer instrumento por meio do qual vamos trabalhar o mundo a fim de reproduzir nossa vida material. A idéia abrange tudo que promova o domínio humano ou o controle da natureza com finalidade produtiva". EAGLETON, Terry. Marx estava certo. Rio de Janeiro: Nova Fronteira, 2012, p. 33.
} 
consumo e entre produção e distribuição, e se contrapõe às idéias de diferenciação entre as fases da mercadoria e independência da produção:

A produção não produz, pois, unicamente, o objeto de consumo, mas também o modo de consumo, ou seja, produz objetiva e subjetivamente. A produção cria, pois, os consumidores (...) De modo que a produção não somente produz um objeto para o sujeito, mas também um sujeito para o objeto. ${ }^{250}$

Terry Eagleton esclarece que o marxismo concebe a categoria da produção na sua forma "mais rica e abrangente; um motivo por que a teoria da história de Marx se sustenta é o fato de que os bens materiais jamais são apenas bens materiais, mas encerram a promessa do bem-estar humano". Em suma: o tão criticado "determinismo mecanicista" pressupõe mais do que o fator econômico. Trata-se não somente "de uma questão de comportamento de mercados, mas se refere à forma como nos tornamos seres humanos, e não só à forma como nos tornamos corretores". Ou, em outras palavras, "trata-se apenas de outra forma de dizer que o fator econômico é o alicerce da nossa vida juntos, é o elo vital entre o biológico e o social". ${ }^{251}$

Na ponta da distribuição, Marx alega que é, na verdade, a forma de distribuição que determina a produção; porém, antes de ser pura e simplesmente distribuição de mercadorias, ela é a distribuição dos instrumentos de produção o que implica, por conseguinte, na propriedade privada e na subordinação dos indivíduos à relações de produção. Se a distribuição sofre uma modificação, a produção também e, sob esse prisma, "a necessidade de consumo determina a produção". E Marx prossegue: “o resultado a que chegamos não é que a produção, a distribuição, a troca, o consumo, são idênticos, mas que todos eles são membros de uma totalidade, diferenças em uma unidade". ${ }^{252}$

Marx assinala igualmente que cada modo de produção cria suas relações de direito e suas formas de governos: "a grosseria e a incompreensão consistem precisamente em não relacionar senão fortuitamente umas às outras, em não enlaçar, senão no domínio da reflexão, elementos que se acham unidos organicamente". ${ }^{253}$

\footnotetext{
${ }^{250}$ MARX, Karl. Contribuição à crítica da Economia Política. São Paulo: Expressão Popular: 2008, p. 248.

${ }^{251}$ EAGLETON, Terry. Marx estava certo. Rio de Janeiro: Nova Fronteira, 2012, p. 103, 104, 117.

${ }^{252}$ Idem, Ibidem, p. 256.

${ }^{253}$ Idem, Ibidem, p. 243.
} 
O tráfego entre a base a superestrutura não é uma rua de mão única, e "nem os modos de produção produzem apenas aquelas idéias ou instituições que servem a seus propósitos. Se isso fosse verdade, o próprio marxismo seria impossível". ${ }^{254}$ Com estrutura econômica, ou base, o pensador alemão se refere às forças e relações de produção; a superestrutura, por sua vez, abarca as instituições políticas, a religião e a cultura que dão, por sua vez, o suporte para a base, no sentido prático e ideológico:

A base pode dar origem à superestrutura, mas a superestrutura é importante para a existência continuada da base. Sem o apoio do Estado, do sistema jurídico, dos partidos políticos e da circulação de ideias pró-capitalistas na mídia e em outros lugares, o atual sistema da propriedade poderia estar mais claudicante do que anda nos últimos tempos. Na visão de Marx, esse tráfego de mão dupla era ainda mais evidente nas sociedades pré-capitalistas, em que o direito, a religião, a política, os laços de sangue e o Estado participavam crucialmente na atividade da produção material. ${ }^{255}$

O que se estabelece, então, entre a base e a superestrutura é um tipo de relação que mantém o sistema vivo pela sua retroalimentação. Contudo, existem ainda instituições que podem pertencer ao mesmo tempo à base e a superestrutura: "são templos da ideologia, mas também negócios altamente lucrativos" ${ }^{256}$, como as editoras, a mídia em geral, e a indústria cinematográfica, nos moldes da indústria cultural denunciada por Adorno e Horkheimer.

Em termos mais amplos, a cultura, o direito e a política da sociedade de classes estão ligados aos interesses das classes sociais dominantes. A produção material, não obstante,

(...) Distorce a política, o direito, a cultura e as idéias, contrariando a verdade ao exigir que, em lugar de simplesmente desabrocharem sozinhas, passem boa parte do tempo legitimando a ordem social prevalente. Pensemos no capitalismo contemporâneo, no qual a comoditização (sic) deixou suas digitais encardidas por todo lado, do esporte à sexualidade, de como obter um lugar na primeira fila do céu até o tom ensurdecedor usados pelos repórteres da TV americana na esperança de segurar a atenção dos espectadores para o bem dos anunciantes". ${ }^{257}$

\footnotetext{
${ }^{254}$ EAGLETON, Terry. Marx estava certo. Rio de Janeiro: Nova Fronteira, 2012, p. 96, 97.

${ }^{255}$ Eagleton observa, ademais, que Marx considerava que aqueles que detinham e controlavam a produção material, controlavam igualmente a produção mental; “(...) a afirmação ganha ainda mais força numa era de magnatas da imprensa e barões da mídia do que em sua própria época”. Idem, Ibidem, p. 124.

${ }^{256}$ Idem, Ibidem, p. 126.

${ }^{257}$ EAGLETON, Terry. Marx estava certo. Rio de Janeiro: Nova Fronteira, 2012, p. 98.
} 
As superestruturas são "essenciais porque existe exploração", segue Eagleton; se não existisse, a produção cultural não precisaria atuar na legitimação do sistema presente. Entretanto, “é verdade que boa parte da arte e da literatura tem sido profundamente crítica quanto ao status quo”. 258

O olhar de Jameson acerca das relações entre produção e ideologia difere daquele proposto por Marx e seguido por Eagleton. Sob esse prisma, Adorno parece ser a base de suas escolhas teóricas; sua posição, nas suas próprias palavras,

(..) Is that everything changes when you grasp base-andsuperestructure not as a full-fledged theory in its own right, but rather as the name for a problem whose solution is always unique, ad hoc intention". 259

Nesse sentido, considera a definição de Engels de "interação recíproca" como "positivistic science of textbooks of his Day". ${ }^{260}$

Pode-se sustentar que Jameson segue o método de Adorno, que diverge, pois, do materialismo histórico do marxismo ortodoxo: “(...) Adorno foi, para mim, uma descoberta metodológica crucial nos anos de declínio da era Eisenhower, quando parecia urgente criar alguma concepção da dialética no contexto da América do Norte". ${ }^{261}$

Uma vez identificada a questão das estruturas, segue Jameson, ela não deve ser a primordial, ou corre-se o risco de "jogar o bebê fora junto com a água do banho": "it is when one has decided in advance that the relationship to be thus established is no longer an interesting formula, of throwing the baby out with the water (...)". ${ }^{262}$

Nesse sentido, Adorno esclarece sua posição em um dos aforismos de Mínima Moralia:

\footnotetext{
258 Vale destacar que Eagleton entende a superestrutura "menos como um lugar do que como um conjunto de práticas. O próprio Marx provavelmente não encarava a superestrutura assim, mas essa é uma refinação útil ao seu argumento". EAGLETON, Terry. Marx estava certo. Rio de Janeiro: Nova Fronteira, 2012, p. 127.

259 “(...) Tudo muda quando você perceber a base-e-superestructura não como uma teoria de pleno direito, mas sim como o nome para um problema cuja solução é sempre única, a intenção ad hoc" (tradução nossa). JAMESON, Fredric. Base and Superestructure. In: The Jameson Reader. Malden: Blackwell publishing, 2005, p. 120.

${ }^{260}$ Idem, Ibidem.

${ }^{261}$ JAMESON, Fredric. O Marxismo Tardio: Adorno ou a persistência da dialética. São Paulo, Boitempo, 1997, p. 17.

262 “(...) É quando se decidiu antecipadamente que a relação a ser estabelecida, assim, já não é uma fórmula interessante, a de jogar o bebê junto com a água do banho (...)" (tradução nossa). JAMESON. Fredric. Base and Superestructure. In: The Jameson Reader. Malden: Blackwell publishing, 2005, p. 121.
} 
Não sendo o sentido independente da gênese, facilmente se pode encontrar em tudo que repousa sobre a determinação material ou a medeia o traço da falsidade, da sentimentalidade, até mesmo do interesse disfarçado e nisso duplamente venenoso. Se, porém, fôssemos agir radicalmente conforme isso, erradicaríamos então junto com o não verdadeiro também todo o verdadeiro, tudo aquilo que, embora impotente, forceja por destacar-se do círculo da prática universal, toda antecipação quimérica da condição mais digna, e seguiríamos direto para a barbárie atribuída à cultura indiretamente, como produto. (...) De resto, a acentuação do elemento material perante o espírito como mentira desenvolve uma duvidosa afinidade eletiva com a economia política, cuja crítica imanente se exerce, comparável ao entendimento entre polícia e submundo (...). ${ }^{263}$

A partir deste último trecho, evidencia-se o esforço do frankfurtiano de salvaguardar a semi-autonomia da cultura, ao menos daquela parcela que resiste à falsidade e contém a verdade. A conclusão metodológica é a de que se deve denunciar a cultura ao passo que ela é perpetuada e perpetuá-la enquanto a denuncia incansavelmente. É na concepção de cultura como filosofia, a qual, todavia, "perdeu o momento de sua realização", que reside o poder utópico de manter viva a própria ideia de filosofar - como de produzir cultura - ao mesmo tempo já atestando sua impossibilidade. Nas palavras de Jameson, ainda,

(...) In the same way, according to my own proposal, the stigmatizing term of superstructure needs to be retained in order to remind us the gap that has to be overcome in some more adequate way than forgetting about it. ${ }^{264}$

Para além das questões de método, a aporia se dá no fato de que "antes que cheguemos a refletir sobre a realidade, já estamos envolvidos com ela de forma prática e emocional, e nosso raciocínio acontece dentro de tal contexto" ${ }^{265}$. Ou seja, nossa própria forma de pensar é moldada pelas realidades materiais de uma dada era.

\footnotetext{
${ }^{263}$ ADORNO, Theodor. Minima Moralia: reflexões a partir da vida lesada. Rio de Janeiro: Beco do Azougue, 2008, p. 40.

264 ، (...) Da mesma forma, de acordo com a minha própria proposta, o termo estigmatizado da superestrutura precisa ser mantido, a fim de nos lembrar a lacuna que tem de ser superada de alguma forma mais adequada do que esquecêlo)" (tradução nossa). JAMESON, Fredric. Base and Superestructure. In: The Jameson Reader. Malden: Blackwell publishing, 2005, p. 121, 122.

${ }^{265}$ EAGLETON, Terry. Marx estava certo. Rio de Janeiro: Nova Fronteira, 2012, p. 119.
} 
Assim sendo, se "a consciência é totalmente social e prática, razão pela qual a linguagem é seu sinal supremo" ${ }^{266}$, então a consciência de uma época se expressa igualmente em uma determinada linguagem; no contemporâneo, trata-se da linguagem do pós-modernismo, que atua, porém, não como consciência esclarecida de si, mas como ideologia, correspondendo às aparências e ocultando a realidade - a exploração do trabalho. ${ }^{267}$

Seguindo esssa linha de raciocínio, pode-se dizer então que o pós-modernismo é a ideologia do neoliberalismo. "O que caracteriza a pós-modernidade na área cultural", afirma Jameson, "é a supressão de tudo que esteja fora da cultura comercial, a absorção de todas as formas de arte, alta e baixa, pelo processo de imagens". ${ }^{268}$ Com a "redescoberta" do mercado e as liberdades políticas transmutadas em liberdades de consumo, "o retorno do estético" e o aclamado fim da política, "a atenção estética encontra-se transferida para a vida da percepção, abandonando os antigos objetos que a organizavam e retornando para a subjetividade", e a vida torna-se, em grande medida, uma mostra aleatória e ampla de sensações. ${ }^{269}$

Com efeito, numa tal conjuntura, o capital especulativo encontrou um ambiente propício ao seu desenvolvimento. Na tentativa de compreensão das transações financeiras que animam o sistema, pautadas pelo frisson dos fluxos de informações em escala global (desafiando nossa capacidade de representação dos fenômenos), Jameson indaga-se: “(...) Porque estamos prestando atenção aos investimentos e ao mercado de ações do que à produção industrial que, em todo caso, está prestes a desaparecer? Como se pode, para começar, obter lucros sem produção?"270 A questão que se impõe é, se, de fato, a produção está prestes à desaparecer, ou se ela apenas se transferiu para outra região; como assinala Eagleton, "boa parte da produção industrial foi terceirizada, com emprego de mão de obra de regiões com baixos salários no

\footnotetext{
${ }^{266}$ Quando fala em consciência, escreve Eagleton, "Marx nem sempre está pensando em ideais e valores implícitos em nossas atividades cotidianas, mas, às vezes, está pensando em sistemas mais formais de conceitos, como o direito, a ciência, a política e congêneres. E seu argumento é que as formas de raciocínio são, em última instância, determinadas pela realidade social". Idem, Ibidem, p. 118.

${ }^{267}$ SCHWARZ, Roberto. Cultura e Politica. São Paulo: Paz e Terra, 2001.

${ }^{268}$ JAMESON, Fredric. A cultura do dinheiro: ensaios sobre a globalização. Petrópolis: Vozes, 2001, p. 142.

${ }^{269}$ Idem, Ibidem, p. 116.

${ }^{270}$ Em complemento a isso, assinala Jameson: “(...) em qualquer região de produção específica (...) chega o momento em que a lógica do capitalismo, confrontando-se com a saturação dos mercados locais ou mesmo estrangeiros, determina o abandono deste tipo específico de produção, juntamente com suas fábricas e força de trabalho treinada, e os abandona à ruína enquanto foge em direção a empreendimentos mais lucrativos. Idem, Ibidem, p. 143, 163.
} 
mundo subdesenvolvido, levando alguns ocidentais (...) a concluir que a indústria havia sumido por completo do planeta". ${ }^{271}$

É possível afirmar, sob essa ótica, que o capital como agente de produção tenha enfraquecido, porém não cessado de existir, como atesta a produção chinesa, por exemplo, a partir, notadamente, da década de 90. Se, para Marx, o capital pode ser dividido em dois momentos essenciais - produção e fonte de renda (juros) ${ }^{272}$ - então, por extensão, ele "não é nada sem trabalho assalariado, sem valor, dinheiro, preços etc.” ${ }^{273}$, e, seguramente, sem maisvalia. "O juro e o lucro, como formas de distribuição, supõem o capital como agente da produção. São também modos de reprodução do capital". ${ }^{274}$ Vale lembrar ainda que, nos termos do filósofo alemão, a esfera produtiva já produz também o modo de consumo, uma vez que o modo de distribuição determina a produção.

A transformação da riqueza gerada na produção em capital, e a conseqüente autonomização do processo de acumulação acabaram por imprimir sua própria lógica sobre a produção e consumo de bens, bem como sobre o próprio sujeito - seja ele o empresário ou o trabalhador. Isso porque, para Jameson, a autonomização financeira "implica um novo estado ontológico em livre flutuação, um estado no qual o conteúdo (...) foi definitivamente suprimido em favor da forma". ${ }^{275}$

Segue-se que esse deslocamento do capital se dá num duplo movimento, segundo nosso autor. O primeiro ocorre quando ele se transmuda para outras regiões geográficas. Depois, num segundo momento "o capital de um centro ou região abandona de vez a produção a fim de buscar sua maximização em espaços não-produtivos", em que o exemplo máximo é a especulação imobiliária do espaço urbano. As cidades pós-modernas, informatizadas e globais, são o resultado dessa "dupla desterritorialização": "a especulação imobiliária é então uma face de um processo cuja outra face está na desterritorialização de último grau da própria globalização". ${ }^{276} \mathrm{~A}$ globalização, sob esse aspecto, é antes um ciberespaço multinacional do que um novo espaço que substitui os antigos - nacionais e imperiais. Nesse cenário, o "capital alcançou sua

\footnotetext{
${ }^{271}$ EAGLETON, Terry. Marx estava certo. Rio de Janeiro: Nova Fronteira, 2012, p. 7.

${ }^{272}$ MARX, Karl. Contribuição à crítica da Economia Política. São Paulo: Expressão Popular: 2008, p. 251.

${ }^{273}$ EAGLETON, Terry. Marx estava certo. Rio de Janeiro: Nova Fronteira, 2012, p. 258.

${ }^{274}$ MARX, Karl. Contribuição à crítica da Economia Política. São Paulo: Expressão Popular: 2008, p. 250.

275 JAMESON, Fredric. A cultura do dinheiro: ensaios sobre a globalização. Petrópolis: Vozes, 2001, p.162.

${ }^{276}$ Idem, Ibidem, p. 164.
} 
desmaterialização máxima, com mensagens que passam instantanemante de um ponto nodal ao outro por todo o que antes chamávamos de globo, o antigo mundo material". ${ }^{277}$

Essa nova lógica do capitalismo financeiro gera, na visão de Jameson, formas mais radicais de abstração - em que novos conteúdos desterritorializados pós-modernos entram em circulação - distintas das abstrações autônomas modernas, que correspodiam às operações bancárias e de crédito; “o que é preciso teorizar é uma modificação na própria natureza dos símbolos culturais e dos sistemas em que operam". ${ }^{278}$

A novidade da cultura na pós-modernidade é, de fato, o consumo da plenitude visual e do instante, em uma espécie de presentre perpétuo; "o modernismo consistiu, acima de tudo, no sentimento de que a estética só podia ser realizada e concretizada quando ela era algo mais do que o simplesmente estético". O pós-modernismo representa, seguindo Jameson, o conteúdo monetário abstrato, “o universal vazio incessantemente preenchido com novos conteúdos mutantes, (...)[de] banalidades em formas visuais elegantes que se oferecem conscientemente ao consumo visual". ${ }^{279}$ Seus comentários são, aqui, certeiros:

\footnotetext{
De repente, uma visibilidade universal perniciosa que parecia não comportar uma alternativa utópica é bem-vinda e festejada: este é o verdadeiro momento da sociedade de imagem, na qual o sujeito humano, exposto (...) a um bombardeamento de até mil imagens por dia (...) começa a viver uma relação bastante diferente com o espaço e o tempo, com a experiência existencial, assim como com o consumo da cultura. ${ }^{280}$
}

Atesta-se na pós-modernidade a expansão da esfera da cultura de modo que ela passa a coincidir com a sociedade de consumo enquanto tal (pela penetração da forma-mercadoria); 0 espaço social metamorfoseia-se num ambiente saturado por imagens e "já não se limita às formas anteriores, tradicionais ou experimentais, mas é consumido a cada momento da vida cotidiana, nas compras, nas atividades profissionais, nas várias formas de lazer televisuais (...)" ${ }^{281}$, enfim, em todos os pormenores da existência.

A noção da dissolução da semi-autonomia da cultura na pós-modernidade - a fusão da base e da superestrutura advogada por Jameson - é tributária da abrangência total do estético,

\footnotetext{
${ }^{277}$ Idem, Ibidem, p. 164.

${ }^{278}$ Idem, Ibidem, p. 164.

279 JAMESON, Fredric. A cultura do dinheiro: ensaios sobre a globalização. Petrópolis: Vozes, 2001, p.103, 167.

${ }^{280}$ Idem, Ibidem, p. 115.

${ }^{281}$ Idem, Ibidem, p. 115.
} 
quando "a esfera da cultura se expande a ponto de aculturar tudo, [e], de uma maneira e de outra, a distinção tradicional ou a 'especificidade' da estética (ou mesmo da cultura) é necessariamente obscurecida ou totalmente perdida". ${ }^{282}$

Sendo assim, Jameson aponta, primeiramente, para a impossibilidade da autonomia da obra-de-arte e do estético na pós-modernidade, e, depois, para o papel da cultura como agente que permeia todos os aspectos da vida, inclusive e, sobretudo, a acumulação de capital, como peça chave para sua valoração.

Do ponto de vista da análise, nosso autor, ao seguir Adorno, parte de suas considerações pela análise dos fenômenos culturais e obras-de-arte específicas (os sapatos de Van Gogh e Andy Warhol), e preserva, de alguma maneira, a semi-autonomia da cultura ao menos como condição de possibilidade da crítica.

Cabe apontar, ainda, que esse espaço multinacional em que a produção cultural é pósmoderna, e o pós-modernismo é a lógica do capitalismo tardio, não alcança todas as regiões do globo, nem materialmente, nem tecnicamente. $\mathrm{O}$ "jogo de entidades monetárias que não precisa nem de produção (...) nem de consumo" e que circula "sem nenhuma referência a um tipo anterior de conteúdo", assim como a linguagem do pós-modernismo, pode estar restrito às regiões avançadas, mas não às subdesenvolvidas ou em vias de desenvolvimento.

Dessa maneira, é possível que sua tese seja eficiente para explicar a realidade dos países desenvolvidos. Parece que no atual estado das coisas, sobretudo nesse espaço globalizado, a espetacularização se intensificou exponencialmente, e a realidade passou a funcionar como publicidade de si mesma,

(...) Sugerindo um novo domínio ou dimensão cultural que é independente do antigo mundo real, não porque, como no período moderno (ou até no romântico) a cultura se retirou daquele mundo real e se refugiou no espaço autônomo da arte, mas antes porque o mundo real já está impregnado e colononizado pelo cultural, de tal forma que não há nenhum espaço externo a partir do qual se pode ver o que lhe falta. ${ }^{283}$

É válido, nesse ponto da argumentação, resgatar as considerações do sociólogo inglês Scott Lash, em Sociologia do pós-modernismo, a fim de contrapor a posição de Jameson da

${ }^{282}$ Idem, Ibidem, p. 116.

${ }^{283}$ JAMESON, Fredric. A cultura do dinheiro: ensaios sobre a globalização. Petrópolis: Vozes, 2001, p. 172. 
fusão das esferas. Lash defende a idéia de que a modernização foi um processo de diferenciação cultural, enquanto o pós-modernismo seria um de "des-diferenciação"; para ele, a modernização seria um longo processo histórico de autonomização cultural iniciado no Renascimento, e que alcança seu ápice com o advento do modernismo do final do século XIX. Sob essa ótica, mesmo a sociologia clássica de um Weber, por exemplo, seria mais um sintoma da lógica subjacente (que, todavia, teoriza sobre o processo em questão). ${ }^{284}$

Diferentemente de Jameson, o autor concebe o pós-modernimso em termos exclusivamente culturais: "penso (...) que o pós-modernismo está confinado ao âmbito da cultura. O pós-industrialismo é uma propriedade importante das economias capitalistas avançadas contemporâneas. Mas é uma propriedade estritamente econômica, não cultural”. ${ }^{285}$

O ponto de partida de Lash é a concepção funcionalista-estrutural da modernização social por meio da diferenciação, emprestada da sociologia tradicional. Contudo, seguindo Weber em seus ensaios sobre a sociologia da religião assim como Habermas na Teoria da ação comunicativa, sua intenção é restringir esta relação diferenciação-modernização à esfera da cultura.

Por conseguinte, a modernização é um processo de diferenciação em que o plano cultural desvincula-se por completo da religião e dos rituais, secularizando-se, ao passo que autonomizase. A natureza e o espiritual eram, outrora, indiferenciados:

A diferenciação e autonomização instauram a possibilidade de desenvolvimento do realismo tanto na arte quanto na epistemologia. (...) Uma maior diferenciação e autonomização nos conduzem a uma modernidade cultural madura. No moderno, cada uma das esferas culturais obtém a mais plena autonomia possível. Cada esfera alcança o que Weber chamou Eigengesetzlichkeit. Isso significa que cada esfera começa a se auto-regular. ${ }^{286}$

A noção de auto-regulação weberiana supõe que cada esfera passe a desenvolver-se de acordo com suas próprias convenções e modos de avaliação - de acordo com seus próprios valores. Em última instância, o valor de uma proposição de uma dada esfera se torna menos

\footnotetext{
${ }^{284}$ LASH. Scott. Sociología del posmodernismo. Buenos Aires: Avellaneda, 1997, p. 13, 14.

285،"Pienso (...) que el posmodernismo está confinado al ámbito de la cultura. El pos-industrialismo es una propriedad importante de las economías capitalistas contemporáneas. Pero es una propriedad estrictamente económica, no cultural. Idem, Ibidem, p. 20.

${ }^{286}$ Idem, Ibidem, p. 23, 26.
} 
dependente do grau de sua reprodução da realidade do que dos argumentos e testemunhos acrescidos ao discurso para respaldar as proposições. Por extensão, o "modernismo maduro" nas esferas estética, prático-moral e teórica significa uma ruptura com a práxis que é, essencialmente, o oposto à autolegislação.

Vale apontar para o caráter racionalista do modernismo, de que a própria sociologia clássica, de acordo com o autor, dá testemunho: "a preocupação pela ordem social dos clássicos Simmel, Durkheim e Weber era equivalente à busca de um conjunto de elementos regulares e da racionalidade mesma na própria vida social". ${ }^{287}$ De todo modo, observa Lash, havia, nessa busca, uma preocupação moral com relação ao conjunto racional de disposições sociais, que parece ter desaparecido das premissas teóricas dos pensadores pós-modernos.

No pós-modernismo essa diferenciação sofre um revés; o que se dá é, antes, um processo de "des-diferenciação", em que o autor paradigmático é, para Lash, Walter Benjamin e sua idéia da perda da aura (na medida em que a cultura já não se encontra como um domínio separado do social). A pós-modernidade assiste à perda da autonomia na interação entre os tipos de objetos culturais produzidos - estéticos, teóricos, ou éticos, por exemplo -, na aproximação do cultural com o social e ainda nas condições de produção e consumo.

Em conformidade com Jameson, o autor alega que o estético começa a colonizar as esferas teóricas e político-moral, e que a vida cotidiana passa a ser inundada e composta por representações. Sua idéia da des-diferenciação das esferas trata, na verdade, daquilo que Jameson descreve como a interpenetração do high e do low - ou seja, do modernismo agora canonizado e da indústria cultural.

Se o modernismo havia diferenciado e autonomizado os papéis do significante, do significado e do referente, o pós-modernismo, pelo contrário, problematiza tais distinções, em especial o estatuto entre significante e referente - em última instância, entre a realidade e a representação.

Nesse sentido, o realismo, defende o autor, fora um primeiro momento no processo de diferenciação, e apontava para a harmonização da social: prometia "estabilidade e ordem tanto na representação quanto na realidade". Dessa maneira, ele não problematizava nem a representação em si mesma, nem a realidade. O modernismo, seguindo essa lógica, seria o ápice: o momento da

287 “(...) La preocupación por el orden social de los clásicos Simmel, Durkheim y Weber era equivalente a la búsqueda de un conjunto de elementos regulares y hasta de racionalidad, en lo social mismo.” Idem, Ibidem, p. 29. 
crise da representação, quando a questão primordial passa a girar em torno das possibilidades do material estético - a racionalidade estética descrita por Adorno em Filosofia da nova música.

O pós-modernismo, em contraposição, considera problemático não o processo de significação, "não a superfície do quadro", mas a realidade ela mesma. A justaposição de objetos em discordância - característica formal cujos primórdios se dão no alto modernismo, com o surrealismo - problematiza o real, assinala Lash. De alguma maneira, os mecanismos inconscientes evocados pelos surrealistas questionam a validade dos fenômenos:

Portanto, o pós-modernismo pode ser considerado também como uma tentativa de resolução de problemas, isto é, como uma busca destinada a elaborar as mudanças e implicações pelas quais a realidade se transforma e se torna frágil pela penetração de imagens invasoras. (...) A autonomização modernista e a autolegislação efetivamente desestabilizaram a representação. A des-diferenciação pós-modernista, por sua vez, instaura o caos, a fraqueza e a instabilidade na nossa experiência da realidade. ${ }^{288}$

A penetração crescente das representações no âmbito social enfraquece a sensação de realidade dos objetos e o acesso às coisas em si mesmas, a ponto de por em xeque a "hegemonia dos objetos reais como objetos de significação social”. Neste ponto, pode-se dizer que Lash está igualmente de acordo com as idéias jamesonianas acerca da colonização do real pelas imagens e seu impacto na percepção do sujeito.

Lash sustenta, como sociólogo, que existem quatro explicações que de certa forma produziram os fenômenos do modernismo e do pós-modernismo: a primeira delas foi a desestabilização da identidade burguesa, pela cultura modernista, e sua restauração na pósmodernidade (algo como o projeto de restauração de classe no neoliberalismo de Harvey). A segunda seria a condição de existência do modernismo dada pela classe operária como ator social, enquanto a cultura pós-modernista é um "catalisador da fragmentação dela". A terceira refere-se às transformações materiais e culturais de seus ambientes, especificamente, as cidades. A última reside nas modificações de ordem econômica, a saber, o neoliberalismo.

\footnotetext{
288 "Por lo tanto, el posmodernismo puede considerarse también como una búsqueda destinada a elaborar las permutaciones e implicaciones por las cuales la realidad se transforma y se vuelve frágil por la penetración de imágenes invasoras. (...) La autonomización modernista y la autolegislación efectivamente desestabilizan la representación. Por su parte, la des-diferenciación posmodernista coloca el caos, la endeblez y la inestabilidad en nuestra experiencia de la realidad."Idem, Ibidem, p. 33.
} 
Há, por fim, duas considerações sobre a questão da cultura na contemporaneidade que são dignas de nota. A primeira delas diz respeito ao conceito de indústria cultural. Segundo Jameson, em Marxismo Tardio, a “indústria cultural” não é uma teoria da cultura em sentido stricto, "não se propõe em absoluto ser uma teoria da cultura (...) mas sim uma teoria de uma indústria". Os produtos da indústria cultural de Adorno "devem ser hoje identificados com os filmes B de Hollywood". O tópico abordado é mais a comercialização da vida, "e os autores estão mais próximos de uma teoria da 'vida cotidiana' do que de uma 'cultura', em qualquer sentido contemporâneo da palavra". Não obstante, a força da análise permanece atual por seu caráter premonitório, na medida em que foram elencadas uma série de tendências que foram mantidas, por assim dizer, na sociedade das imagens. $\mathrm{O}$ que eles não puderam antecipar foi a "tranformação dialética da quantidade em qualidade que a intensificação do processo acarretaria. Sua teoria permanece, portanto, não uma Kulturkritik, mas uma Ideologiekritik (...)". ${ }^{289}$

A segunda refere-se às considerações presentes no estudo de Chin-Ta $\mathrm{Wu}$ sobre a privatização da cultura no mundo anglo-saxão. Sob a égide do Estado Neoliberal, a crescente retirada de investimentos públicos no setor foi “compensada" pela intervenção corporativa:

Com freqüência cada vez maior, criaram-se, a partir dos anos
1980, coleções corporativas nos dois lados do Atlântico.
Usando seu poder econômico, as empresas modernas, armadas
com seus próprios curadores e departamentos de arte,
emularam ativamente as prerrogativas anteriores dos museus e
galerias de arte públicos, organizando e apresentando coleções
próprias em seus países e no exterior. Também transformaram
as galerias e museus de arte em veículos de relações públicas,
assumindo as funções e explorando o status social de que
desfrutam as instituições culturais em nossa sociedade. ${ }^{290}$

Desse modo, a arte contemporânea passou a funcionar como moeda simbólica para as corporações nas democracias capitalistas ocidentais, preocupadas com a imagem da empresa perante o consumidor; em suma: a arte como forma de propaganda, apontando, sob outro prisma, para a fusão da base e superestrutura defendida por Jameson.

\footnotetext{
${ }^{289}$ JAMESON, Fredric. O Marxismo Tardio: Adorno ou a persistência da dialética. São Paulo, Boitempo, 1997, p. 188, 189.

${ }^{290}$ WU, Chin-Tao. Privatização da Cultura: a intevenção corporativa nas artes desde os anos 80. São Paulo: Boitempo, 2006, p. 26.
} 
O idealismo inteligente está mais próximo do materialismo inteligente do que o materialismo não inteligente.

(Lênin apud Jameson, Marxismo e Forma.)

Postmodernism is not an exclusively aesthethic or stylistic term (...) which is therefore to be understood as an attempt to theorize the specific logic of cultural production of that third stage, and not as yet another disembodied cultural critique or diagnosis of the spirit of age. (...) (Fredric Jameson, Marxism and Postmodernism.)

\section{Considerações finais}

De acordo com Perry Anderson, em Origens da pós-modernidade, o mérito de Jameson em Pós-modernismo ou a lógica cultural do capitalismo tardio consistiu no desenvolvimento de cinco pontos principais: a identificação do campo de forças da pós-modernidade; um escalonamento das identidades sob ela; sua tese - fusão da base-e-superestrutura e da dominância cultural do pós-modernismo; a questão da luta de classes versus o pluralismo das políticas de identidade e, finalmente, como proposta, o mapeamento cognitivo.

Até então, segue Anderson,

Toda sondagem do pós-moderno fora setorial. Levin e Fiedler detectaram-no na literatura; Hassan estendeu-o à pintura e à musica, ainda que mais por alusão que investigação; Jencks concentrou-se na arquitetura; Lyotard deteve-se na ciência; Habermas lidou com a filosofia. A obra de Jameson teve outro escopo - uma majestosa expansão do pós-moderno por praticamente todo o espectro das artes e grande parte do discurso sobre elas. $O$ resultado é um painel da época incomparavelmente mais rico e abrangente do que qualquer outro registro dessa cultura. ${ }^{291}$

${ }^{291}$ ANDERSON, Perry. As Origens da pós-modernidade. Rio de Janeiro: Jorge Zahar, 1999, p. 69. 
O poder do pós-modernismo reside no fato de ser hegemônico; no seu auge, o modernismo não havia passado de um enclave. Como o próprio Jameson afirma, isso não significa que ele esgote toda produção cultural, na medida em que qualquer "hegemonia, como insistiu Raymond Williams, é um sistema 'dominante' e não total, um sistema que virtualmente garante - devido a suas definições seletivas da realidade - a coexistência de formas 'residuais' e 'emergentes' que a ele resistem”. ${ }^{292}$

Se o pós-modernismo é dominante, na era da globalização, a conseqüência é que ele não ficou restrito ao seu lugar de origem. Entretanto, sua tendência global não se manifesta como denominador comum das sociedades capitalistas avançadas, mas como projeção do poder de uma sobre as outras: “os líderes dos Estados Unidos conseguiram, com considerável apoio publico doméstico, projetar no mundo a idéia de que os valores neoliberais norte-americanos de liberdade são universais e supremos, e de que se deve morrer por tais valores (...)". ${ }^{293}$

A conjuntura para a emergência do discurso pós-moderno "pode ser vista como produto da derrota política da geração radical dos anos 60”. ${ }^{294}$ A prosperidade da nova classe média ocidental somada à desilusão política forneceu o contexto adequado para a proliferação do pósmodernismo.

Com efeito, observa Jameson, principalmente nos Estados Unidos, o desenvolvimento do capitalismo monopolista pós-industrial trouxe consigo um

(...) Ocultamento crescente da estrutura de classe, por meio de técnicas de mistificação praticadas pelos media e particularmente pela propaganda em sua enorme expansão, desde o começo na guerra fria. Em termos existenciais, o que isso significa é que nossa experiência não é mais inteira: não somos mais capazes de intuir qualquer conexão entre as preocupações da vida privada, enquanto esta segue seu curso dentro das paredes e confinamentos da sociedade afluente, e as projeções estruturais do sistema no mundo exterior, sob a forma de neocolonialismo, opressão e guerra contrarevolucionária. (...) é no contexto do [capitalismo monopolista] (sou tentado a chamá-lo de marxismo pós-industrial) que os grandes temas da filosofia de Hegel - a relação da parte com o todo, a oposição entre o concreto e o abstrato, o conceito de

\footnotetext{
292 ANDERSON, Perry. As Origens da pós-modernidade. Rio de Janeiro: Jorge Zahar, 1999, p. 76.

${ }^{293}$ HARVEY, David. O Neoliberalismo: história e implicações. São Paulo: edições Loyola, 2008, p. 220.

${ }^{294}$ ANDERSON, Perry. As Origens da pós-modernidade. Rio de Janeiro: Jorge Zahar, 1999, p. 96.
} 
totalidade, a dialética da aparência e da essência, a interação entre sujeito e objeto - estão novamente na ordem do dia". 295

Este é o momento, como aponta Terry Eagleton, do suposto fim do marxismo, e da persistência do capitalismo, à despeito de algumas alegações de que a sociedade é, agora, pósindustrial. O deslocamento do investimento da manufatura para a indústria de serviços, de finanças e de comunicações foi antes a tentativa de salvação do que um abandono de "um velho mundo mau em troca de um corajoso mundo novo.(...) Não foram as ilusões sobre o novo capitalismo, mas a desilusão quanto à possibilidade de mudá-lo que mostrou ser o fato decisivo". 296

Nesse sentido, Eagleton afirma igualmente que o que forjou a cultura do pósmodernismo, sua recusa às grandes narrativas e seu anúncio do Fim da História foi, "acima de tudo, a convicção de que o futuro era apenas uma repetição do presente. (...) Assim, o que ajudou a desacreditar o marxismo foi, sobretudo, uma sensação arrepiante de impotência política". ${ }^{297}$

Para além da obra singular de Jameson, "a questão pós-moderna torna-se a grande questão cultural na América dos anos 80”. ${ }^{298}$ Uma vez em alta as correntes desconstrutivistas, idéias como as de totalidade não encontravam espaço para seu desenvolvimento. Avesso ao pensamento dialético,

\footnotetext{
${ }^{295}$ JAMESON, Fredric. Marxismo e Forma. São Paulo: Hucitec, 1985, p 7-8.

${ }^{296}$ EAGLETON, Terry. Marx estava certo. Rio de Janeiro: Nova Fronteira, 2012, p. 8.

${ }^{297}$ Idem, Ibidem, p. 8.

${ }^{298}$ CUSSET, François. Filosofia Francesa. A influência de Foucault, Derrida, Deleuze \& CiA. Porto Alegre: Artmed, 2008, p. 197.

${ }^{299}$ Ismail Xavier e Iumna Simon, prefácio a Marxismo e Forma. JAMESON, Fredric. Marxismo e Forma. São Paulo: Hucitec, 1985, p vii.
}

(...) Como o próprio Jameson reclama em vários lugares, esse contexto favorece a fragmentação e a compartimentalização, conferindo a cada ideologia seu devido lugar no vasto mercado editorial, cuja produção transita rapidamente pelas eficazes bibliotecas. Frente a tal congestionamento bibliográfico, não é fácil evitar uma espécie de saturação referencial, para não dizer ecletismo, no emaranhado da qual o pesquisador deve se situar para poder dialogar com seus pares, sobretudo se forem opositores. A reflexão marxista de Jameson traz o estigma desse contexto de produção cultural, onde a Universidade tem sua força e prestígio. ${ }^{299}$ 
Segundo Alex Callinicos, em Against Postmodernism, o marxismo de Jameson distinguese essencialmente por seu imperativo de totalizar, na tentativa de conceitualizar os vários fragmentos da vida social num integrado conjunto de relações. Seu método da totalidade pode ser caracterizado por um duplo movimento; o primeiro, conforme descrito em $O$ Inconsciente Político, como uma "causa ausente, inacessível exceto pela análise formal", em que a História seria o horizonte final, em uma espécie de negação da totalidade.

O segundo reside na construção teórica por meio das mediações dos diversos elementos (fragmentos) da formação social - "do pscicológico ao social, e na verdade, do social ao econômico" 300; essa mediação opera, no entanto, pelas diferenças estruturais e não por sua identidade, em contraposição à noção hegeliana de totalidade expressiva. Não obstante, Callinicos assinala que o movimento de Jameson da totalidade, no que tange à conceitualização do pós-modernismo, é antes uma relação da arte pós-moderna com a fase multinacional do desenvolvimento do capitalismo, e, precisamente, um exemplo do mesmo tipo de erro da crítica feita por Althusser à totalidade expressiva:

(...) This looks a lot more like a relationship of homology than one of structural difference (...) The trouble is that Jameson's tendency to reduce the diversity of social life to exemplars of a single essence runs the risk of giving totalization - or rather Marxist totalization, which, unlike poststructuralism, is explict in its attempt to relate difference practices as parts of the same whole - a bad name. ${ }^{301}$

Cabe, aqui, transpor um trecho de Marxism and Postmodernism, em que Jameson explicita tal metodologia:

(...) My approach to postmodernism is a totalizing one. (...) A more global characterization of the secret affinities between those apparently autonomous and unrelated domains, and the rhythms and hidden sequences of things we normally remember only in isolation and one by one, is a unique

\footnotetext{
${ }^{300}$ JAMESON, Fredric. Marxismo e Forma. São Paulo: Hucitec, 1985, p. 5.

301 “(...) Isso parece muito mais como uma relação de homologia do que uma de diferença estrutural (...). O problema é que a tendência de Jameson em reduzir a diversidade da vida social de exemplares a uma única essência corre o risco de dar totalização - ou melhor a totalização marxista, que, ao contrário do pós-estruturalismo, é explicita em sua tentativa de relacionar as diferenças práticas como partes de um mesmo todo - um nome ruim." (tradução nossa) CALLINICOS, Alex. Against postmodernism: a Marxist critique. New York: St Martin's press, 1990, p. 131, 132.
} 
resource, particularly since the history of the preceding few years is always what is least accesible to us. ${ }^{302}$

O impasse metodológico se dá, no mundo em que tudo o que é sólido desmancha no ar, pela resistência do próprio objeto à teorização: sendo a revolução permanente a base material da intelectual e cultural, faz-se necessário a constante "reinvenção das precauções contra aquilo que a minha tradição chama de reificação conceitual". ${ }^{303}$ Contudo, Jameson observa, há um paradoxo mais profundo na teorização do pós-modernismo, a saber, o de teorizar sobre um sistema historicamente reconhecido como pura heteronomia, e de subsistemas não relacionados de todos os tipos; "there has to be something perverse about the effort to grasp it as an unified system in the first place (...)". ${ }^{304}$

A contradição aparente na busca da compreensão de uma lógica subjacente a processos aparentemente aleatórios - "a unified theory of differentiation" - reside ainda, afirma Jameson, na confusão acerca dos "níveis de abstração": "a system that constitutively produces differences reamains a system (...). The very concept of differentiation (...) is itself a systemic one, or, if you prefer, turns the play of differences into a new kind of identity on a more abstract level". ${ }^{305}$

A totalidade, pois, para Jameson, não é outra senão aquilo outrora chamado de "modo de produção":

(...) Althusserian "structure" is that, and so is 'totality', at least as I use it. (...) Thinking capitalism as a system, synchronic or not; and something like that will remain my own position with respect to that 'stage'or moment of capitalism which projects the cultural logic of what some of us now seem to be calling "postmodernism". ${ }^{306}$

\footnotetext{
302 "Minha abordagem para o pós-modernismo é totalizante. (...) A caracterização mais global das afinidades secretas entre esses domínios aparentemente autônomos e independentes, e os ritmos e seqüências ocultas das coisas que normalmente nos lembram apenas no isolamento e um por um, é um recurso único, particularmente desde que a história dos anos anteriores, é sempre o que é menos acessível para nós." (tradução nossa) JAMESON, Fredric. "Marxism and Postmodernism". In: New Left Review I / 176, July-August 1989, p. 2.

${ }^{303}$ Idem, Ibidem, p. 2.

304 “(...) Tem que haver algo de perverso sobre o esforço para compreendê-lo como um sistema unificado, em primeiro lugar". (tradução nossa) Idem, Ibidem, p. 2.

305 "Um sistema que produz constitutivamente diferenças permanece um sistema (...). O próprio conceito de diferenciação (...) é por si só sistêmico, ou, se você preferir, transforma o jogo das diferenças em um novo tipo de identidade em um nível mais abstrato". (tradução nossa) Idem, Ibidem, p. 3.

306 "A estrutura de Althusser é isso, assim como 'totalidade', pelo menos como eu a utilizo (...). Pensar o capitalismo como um sistema, sincrônico ou não; algo assim permanecerá minha posição em relação a esse 'estágio' ou momento no qual o capitalismo projeta a lógica cultural que parece que alguns de nós agora estamos chamando de "pósmodernismo." (tradução nossa) Idem, Ibidem, p. 4.
} 
Todavia, para ele, modo de produção não é um "sistema total", no sentido proibitivo, mas inclui uma variedade de instâncias contrárias bem como de novas tendências internas - as forças residuais e emergentes - que devem ser geridas, controladas e neutralizadas: "were those heterogenous forces not endowed with an effectivity or their own, the hegemonic project would be unnecessary". 307

O marxismo de Jameson distingue-se igualmente, por seu esforço dialético, que se manifesta, sobretudo, na sua prosa, como descrita no início deste estudo. Para o autor, "no caso do pensamento dialético, certamente, não se pode indefinidamente separar o político do ideológico ou do cultural (...)". O problema formal fundamental que se impõe para o escritor dialético é o da continuidade. Assim, segue ele, “(...) a apresentação explícita do conteúdo por si mesmo, quer na literatura sociológica quer na filosófica, é condenada como um retrocesso à ilusão positivista e empírica que o pensamento dialético se incumbiu de superar" ${ }^{308}$, com o propósito, entre outros, de encontrar o que Jameson denominou de "totalidade ausente".

Há, contudo, outra maneira pela qual é possível evocar essa "causa ausente". Trata-se de uma teoria do não-teorizável, mostrando que o pensamento dialético é, ao mesmo tempo, indispensável e impossível: "é a esta quadratura final do círculo a que Adorno chegou em suas últimas obras, as mais sistemáticas e mais tecnicamente filosóficas, Dialética Negativa e Teoria Estética". ${ }^{309}$

A prática da dialética negativa pressupõe um movimento constante e um distanciamento do "conteúdo oficial de uma idéia (...). A forma mais ampla de Adorno será portanto um constructo mais do que uma narrativa" ${ }^{310}$, e Jameson a associa antes aos monumentos modernistas da arte e da literatura do que à própria filosofia em si mesma.

De maneira esquemática, pode-se caracterizar o modernismo como uma profunda suspeita e ceticismo sobre a possibilidade de se representar qualquer coisa, ou seja, sobre as condições de se "dizer alguma coisa em absoluto diante do fato palpável de que às vezes as

\footnotetext{
307 “(...) Fossem essas forças heterogêneas não dotadas de uma efetividade própria, o projeto hegemônico seria desnecessário". (tradução nossa) Idem, Ibidem, p. 6.

${ }^{308}$ JAMESON, Fredric. Marxismo e Forma. São Paulo: Hucitec, 1985, p. 5, 48.

${ }^{309}$ Idem, Ibidem, p. 48.

310 JAMESON, Fredric. Marxismo e Forma. São Paulo: Hucitec, 1985, p. 48, 50.
} 
coisas a serem ditas ou representadas dão lugar a uma curiosa exploração das estruturas e precondições da fraude eleitoral". ${ }^{311}$

A tentativa aqui empreendida é a de analisar a escrita jamesoniana como sintomática, ao mesmo tempo tomando-o como um esteta; esforço, vale dizer, que ele próprio empreendeu nas suas considerações sobre Adorno em Marxismo Tardio:

Em outros termos, é porque Adorno é tão agudamente consciente da natureza da escrita filosófica como um experimento lingüístico, como Darstellung e invenção da forma, que se torna interessante e apropriado examinar sua própria obra do mesmo modo. Nesse caso, porém, preciso corrigir essa formulação da questão, e insistir assim que, embora Adorno com certeza não possua um "estilo" (como o restante dos mestres modernos, para quem essa categoria é objetiva e histórica), e embora às vezes eu me refira a ele como tal, duvido que a leitura por mim proposta possa ser considerada literária, no sentido restrito ou trivializado. ${ }^{312}$

O fundamental, tomando de empréstimo as palavras de Ismail Xavier e Iumna Simon, "é acompanhar o percurso do pensamento do autor, o movimento e os tateios de sua escrita, onde reside o conteúdo "genuíno". ${ }^{313}$ O conteúdo genuíno da escrita de Jameson pode ser encontrado nas suas frases dialéticas; suas assertivas, sobre o assunto, são esclarecedoras:

Não posso imaginar alguém, com o mais leve sentimento pela natureza dialética da realidade, permaneça insensível ao prazer puramente formal de tais frases, nas quais a mudança de marchas do mundo e o inesperado contato entre categorias e objetos aparentemente não relacionados e distantes encontram súbita e dramática formulação. Não é, gostaria de enfatizar, uma questão de gosto, do mesmo modo que a validade do pensamento dialético não é uma questão de opinião; mas é também verdade que não há nenhuma resposta para quem escolha discutir o assunto nesses termos. ${ }^{314}$

\footnotetext{
311 JAMESON, Fredric. O Marxismo Tardio: Adorno ou a persistência da dialética. São Paulo, Boitempo, 1997, p. 25.

312 JAMESON, Fredric. O Marxismo Tardio: Adorno ou a persistência da dialética. São Paulo, Boitempo, 1997, p. 26.

${ }^{313}$ SIMON, Iumna M., XAVIER, Ismail. Prefácio a Marxismo e Forma. JAMESON, Fredric. Marxismo e Forma. São Paulo: Hucitec, 1985, p xiv.

314 JAMESON, Fredric. O Marxismo Tardio: Adorno ou a persistência da dialética. São Paulo, Boitempo, 1997, p. 24.
} 
É possível acrescentar ainda: não há resposta assim como é uma escolha política na medida em que, como o próprio Jameson afirma, parafraseando Adorno, a densidade da prosa "é um aviso ao leitor do preço que ele tem que pagar pelo pensamento genuíno". ${ }^{315}$ No mundo da divisão do trabalho, da espoliação e da fragmentação, a contribuição de seu pensamento e a urgência de sua denúncia correm o risco de ficar restritos aos especialistas, e não promover a "reordenação da nossa percepção do presente histórico, (...) de modo tal que sejamos capazes de distinguir o contorno de uma prática artística coletiva mais antiga por detrás do individualismo do presente literário e artístico". ${ }^{316}$

A seu favor, por fim, faz-se necessário destacar as palavras de Terry Eagleton:

Certos tipos de teoria - teorias emancipatorias, como em geral são conhecidas - podem atuar como força política no mundo, e não só como uma forma de interpretá-lo. Significa que elas formam um elo entre a maneira como as coisas são e a maneira como elas poderiam ser. (...) Nesse sentido, existe uma relação próxima entre razão, conhecimento e liberdade". ${ }^{317}$

315 JAMESON, Fredric. Marxismo e Forma. São Paulo: Hucitec, 1985, p 2.

${ }^{316}$ Idem, Ibidem, p. 6.

${ }^{317}$ EAGLETON, Terry. Marx estava certo. Rio de Janeiro: Nova Fronteira, 2012, p. 119, 120. 


\section{Bibliografia}

ADORNO, Theodor W., HORKHEIMER, Max. Dialética do esclarecimento: fragmentos filosóficos / Max Horkheimer e Theodor Adorno; tradução Guido Antonio de Almeida. - Rio de Janeiro: Jorge Zahar Ed., 1985.

ADORNO, Theodor W. Filosofia da nova música / Theodor W, Adorno: tradução Magda França. - São Paulo: Perspectiva, 2011.

. Notas de Literatura I / Theodor W. Adorno; tradução; Jorge de Almeida. - São Paulo:

Duas Cidades; Ed. 34, 2003

. Educação e Emancipação / Theodor W. Adorno; tradução de Wolfgang Leo Maar. Rio de Janeiro: Paz e Terra, 1995.

. Minima Moralia: reflexões a partir da vida lesada / Theodor Adorno; tradução Gabriel

Cohn. Rio de Janeiro: Beco do Azougue, 2008.

ANDERSON, Perry. As Origens da pós-modernidade / Perry Anderson; tradução Marcus Penchel. - Rio de Janeiro: Jorge Zahar, 1999.

- The origins of Post-modernity. New York: Verso, 2006.

BAUDELAIRE, Charles. O pintor da vida moderna / Charles Baudelaire; tradução Suely Cassal; apresentação Teixeira Coelho. In: A Modernidade em Baudelaire. Rio de Janeiro: Paz e Terra, 1988.

BENJAMIN, Walter. Charles Baudelaire, um lírico no auge no capitalismo / Walter Benjamin; tradução José Martins Barbosa, Hemerson Baptista - 1.ed. - São Paulo: Brasiliense, 1989. (Obras escolhidas; v.3).

- Magia e técnica, arte e política: ensaios sobre literatura e história da cultura / Walter Benjamin; tradução Sérgio Paulo Rouanet; prefácio Jeanne Marie Gagnebin. - 7. ed. - São Paulo: Brasiliense, 1994. - (Obras escolhidas; v. 1).

- Origem do Drama Barroco Alemão / Walter Benjamin: tradução Sergio Paulo Rouanet. - São Paulo: Brasiliense, 1984.

BÜRGER, Peter. Teoria da Vanguarda. São Paulo: Cosac Naify, 2008.

BUTLER, Christopher. Modernism: a very short introduction. New York: Oxford, 2010.

CALLINICOS, Alex. Against postmodernism: a Marxist critique. New York: St Martin's press, 1990. 
CUSSET, François. Filosofia Francesa. A influência de Fiucault, Derrida, Deleuza \&CiA. Porto Alegre: Artmed, 2008.

DEBORD, Guy. Sociedade do espetáculo. Rio de Janeiro: Contraponto, 1997.

EAGLETON, Terry. “Jameson and Form”. In: New Left Review 59, setembro - outubro/2009.

—. A ideologia da Estética / Terry Eagleton; tradução, Mauro Sá Rego Costa. - Rio de Janeiro: Zahar, 1993.

. As Ilusões do pós-modernismo/ Terry Eagleton: tradução Elisabeth Barbosa. - Rio de Janeiro: Zahar, 1998.

. EAGLETON, Terry. Marx estava certo / Terry Eagleton; tradução Regina Lyra. - Rio de Janeiro: Nova Fronteira, 2012.

HARVEY, David. Condição pós-moderna / David Harvey; tradução Adail Ubirajara Sobral e Maria Stela Gonçalves. - São Paulo: Edições Loyola, 2002.

. O Neoliberalismo: história e implicações. São Paulo: edições Loyola, 2008.

HOBSBAWM, Eric. Era dos extremos: o breve século XX, 1914-1991 / Eric Hobsbawm; tradução Marcos Santarrita; revisão técnica Maria Célia Paoli. - São Paulo: Companhia das Letras, 1995.

JAMESON, Fredric. Pós-modernismo ou a lógica cultural do capitalismo tardio / Fredric Jameson; tradução Maria Elisa Cevasco; revisão da tradução Iná Camargo Costa. - São Paulo: Ática, 2007.

- Marxismo e Forma / Fredric Jameson; tradução Iumna Maria Simon, Ismail Xavier e Fernando Oliboni. - São Paulo: Hucitec, 1985.

. "Base and Superestructure". In: The Jameson Reader. Malden: Blackwell publishing, 2005.

—. "Postmodernism, or The Cultural Logic of Late Capitalism". In: The Jameson Reader. Malden: Blackwell publishing, 2005.

. O Marxismo Tardio: Adorno ou a persistência da dialética / Fredric Jameson; tradução de Luiz Paulo Rouanet. - São Paulo, Boitempo, 1997.

- A cultura do dinheiro: ensaios sobre a globalização / Fredric Jameon; seleção e prefácio Maria Elisa Cevasco; tradução de Maria Elisa Cevasco, Marcos César de Paula Soares.Petrópolis, RJ: Vozes, 2001.

LASH, Scott. Sociología del posmodernismo. Buenos Aires: Avellaneda, 1997. 
LYOTARD, Jean-François. La condition post-moderne. Lonrai: Les Editions de Minuit, 2010. MARX, Karl. Manifesto Comunista / Karl Marx; tradução Álvaro Pina. - São Paulo: Boitempo, 2002.

.Contribuição à crítica da Economia Política / Karl Marx; tradução e introdução de Florestan Fernandes. - 2ed. - São Paulo: Expressão Popular: 2008.

OEHLER, Dolf. O velho mundo desce aos infernos: Auto-análise da modernidade após o trauma de Junho de 1848 em Paris/ Dolf Oehler; tradução José Marcos Macedo. - São Paulo: Companhia das Letras, 1999.

SADER, Emir, Jinkings Iava. As armas da crítica: antologia do pensamento de esquerda: clássicos / Ivana Jinkings, Emir Sader [organizadores; tradução de Paula Almeida]. - São Paulo, SP: Boitempo, 2012.

SAFATLE, Vladimir. "Theodor Adorno: a unidade de uma experiência filosófica plural." In: Pensamento Alemão no século XX: grandes protagonistas e recepção das obras no Brasil, volume I. Jorge de Almeida e Wolfgang Bader - ORGS). - São Paulo: Cosac naify, 2009. WU, Chin-Tao. Privatização da Cultura: a intevenção corporativa nas artes desde os anos 80 / Chin-tao Wu; tradução Paulo Cezar Castanheira. - São Paulo: Boitempo, 2006. 